\title{
On the composition of ammonia-sulfuric-acid ion clusters during aerosol particle formation
}

\author{
S. Schobesberger ${ }^{1}$, A. Franchin ${ }^{1}$, F. Bianchi ${ }^{2}$, L. Rondo ${ }^{3}$, J. Duplissy ${ }^{1,4,5}$, A. Kürten ${ }^{3}$, I. K. Ortega ${ }^{1,6}$, A. Metzger ${ }^{7}$, \\ R. Schnitzhofer ${ }^{8}$, J. Almeida ${ }^{5}$, A. Amorim ${ }^{9}$, J. Dommen ${ }^{2}$, E. M. Dunne ${ }^{10,11}$, M. Ehn ${ }^{1}$, S. Gagné (1, $^{\text {, }}$, L. Ickes ${ }^{3, * *}$, \\ H. Junninen ${ }^{1}$, A. Hansel ${ }^{7,8}$, V.-M. Kerminen ${ }^{1}$, J. Kirkby ${ }^{3,5}$, A. Kupc ${ }^{12}$, A. Laaksonen ${ }^{13,14}$, K. Lehtipalo ${ }^{1}$, S. Mathot ${ }^{5}$, \\ A. Onnela ${ }^{5}$, T. Petäjä ${ }^{1}$, F. Riccobono ${ }^{2}$, F. D. Santos ${ }^{9}$, M. Sipilä ${ }^{1,4}$, A. Tomé ${ }^{9}$, G. Tsagkogeorgas ${ }^{15}$, Y. Viisanen ${ }^{13}$, \\ P. E. Wagner ${ }^{12}$, D. Wimmer ${ }^{1,3}$, J. Curtius ${ }^{3}$, N. M. Donahue ${ }^{16}$, U. Baltensperger ${ }^{2}$, M. Kulmala ${ }^{1}$, and \\ D. R. Worsnop ${ }^{1,14,13,17}$
}

${ }^{1}$ Department of Physics, University of Helsinki, 00014 Helsinki, Finland

${ }^{2}$ Laboratory of Atmospheric Chemistry, Paul Scherrer Institute, 5232 Villigen, Switzerland

${ }^{3}$ Institute for Atmospheric and Environmental Sciences, Goethe University Frankfurt, 60438 Frankfurt am Main, Germany

${ }^{4}$ Helsinki Institute of Physics, University of Helsinki, 00014 Helsinki, Finland

${ }^{5}$ CERN, 1211 Geneva, Switzerland

${ }^{6}$ Laboratoire de Physique des Lasers, Atomes et Molécules, Université de Lille 1, 59655 Villeneuve d’Ascq, France

${ }^{7}$ Ionicon Analytik GmbH, 6020 Innsbruck, Austria

${ }^{8}$ Institute for Ion and Applied Physics, University of Innsbruck, 6020 Innsbruck, Austria

${ }^{9}$ SIM, University of Lisbon and University of Beira Interior, 1749-016 Lisbon, Portugal

${ }^{10}$ School of Earth and Environment, University of Leeds, LS2 9JT Leeds, UK

${ }^{11}$ Finnish Meteorological Institute, Atmospheric Research Centre of Eastern Finland, 70211 Kuopio, Finland

${ }^{12}$ Faculty of Physics, University of Vienna, 1090 Vienna, Austria

${ }^{13}$ Finnish Meteorological Institute, 00101 Helsinki, Finland

${ }^{14}$ Department of Applied Physics, University of Eastern Finland, 70211 Kuopio, Finland

${ }^{15}$ Leibniz Institute for Tropospheric Research, 04318 Leipzig, Germany

${ }^{16}$ Center for Atmospheric Particle Studies, Carnegie Mellon University, Pittsburgh, PA 15213, USA

${ }^{17}$ Aerodyne Research, Inc., Billerica, MA 01821, USA

*now at: Department of Physics and Atmospheric Science, Dalhousie University, Halifax, B3H 3J5, Canada, and Environment Canada, Downsview, Toronto, M3H 5T4, Canada

*** now at: Institute for Atmospheric and Climate Science, ETH Zurich, 8092 Zurich, Switzerland

Correspondence to: S. Schobesberger (siegfried.schobesberger@helsinki.fi)

Received: 2 May 2014 - Published in Atmos. Chem. Phys. Discuss.: 23 May 2014

Revised: 20 September 2014 - Accepted: 6 October 2014 - Published: 7 January 2015

\begin{abstract}
The formation of particles from precursor vapors is an important source of atmospheric aerosol. Research at the Cosmics Leaving OUtdoor Droplets (CLOUD) facility at CERN tries to elucidate which vapors are responsible for this new-particle formation, and how in detail it proceeds. Initial measurement campaigns at the CLOUD stainless-steel aerosol chamber focused on investigating particle formation from ammonia $\left(\mathrm{NH}_{3}\right)$ and sulfuric acid $\left(\mathrm{H}_{2} \mathrm{SO}_{4}\right)$. Experiments were conducted in the presence of water, ozone and
\end{abstract}

sulfur dioxide. Contaminant trace gases were suppressed at the technological limit. For this study, we mapped out the compositions of small $\mathrm{NH}_{3}-\mathrm{H}_{2} \mathrm{SO}_{4}$ clusters over a wide range of atmospherically relevant environmental conditions. We covered $\left[\mathrm{NH}_{3}\right]$ in the range from $<2$ to $1400 \mathrm{pptv}$, $\left[\mathrm{H}_{2} \mathrm{SO}_{4}\right]$ from $3.3 \times 10^{6}$ to $1.4 \times 10^{9} \mathrm{~cm}^{-3}$ (0.1 to $\left.56 \mathrm{pptv}\right)$, and a temperature range from -25 to $+20^{\circ} \mathrm{C}$. Negatively and positively charged clusters were directly measured by an atmospheric pressure interface time-of-flight (APi-TOF) 
mass spectrometer, as they initially formed from gas-phase $\mathrm{NH}_{3}$ and $\mathrm{H}_{2} \mathrm{SO}_{4}$, and then grew to larger clusters containing more than 50 molecules of $\mathrm{NH}_{3}$ and $\mathrm{H}_{2} \mathrm{SO}_{4}$, corresponding to mobility-equivalent diameters greater than $2 \mathrm{~nm}$. Water molecules evaporate from these clusters during sampling and are not observed. We found that the composition of the $\mathrm{NH}_{3}-\mathrm{H}_{2} \mathrm{SO}_{4}$ clusters is primarily determined by the ratio of gas-phase concentrations $\left[\mathrm{NH}_{3}\right] /\left[\mathrm{H}_{2} \mathrm{SO}_{4}\right]$, as well as by temperature. Pure binary $\mathrm{H}_{2} \mathrm{O}-\mathrm{H}_{2} \mathrm{SO}_{4}$ clusters (observed as clusters of only $\mathrm{H}_{2} \mathrm{SO}_{4}$ ) only form at $\left[\mathrm{NH}_{3}\right] /\left[\mathrm{H}_{2} \mathrm{SO}_{4}\right]$ $<0.1$ to 1 . For larger values of $\left[\mathrm{NH}_{3}\right] /\left[\mathrm{H}_{2} \mathrm{SO}_{4}\right]$, the composition of $\mathrm{NH}_{3}-\mathrm{H}_{2} \mathrm{SO}_{4}$ clusters was characterized by the number of $\mathrm{NH}_{3}$ molecules $m$ added for each added $\mathrm{H}_{2} \mathrm{SO}_{4}$ molecule $n(\Delta m / \Delta n)$, where $n$ is in the range 4-18 (negatively charged clusters) or 1-17 (positively charged clusters). For negatively charged clusters, $\Delta m / \Delta n$ saturated between 1 and 1.4 for $\left[\mathrm{NH}_{3}\right] /\left[\mathrm{H}_{2} \mathrm{SO}_{4}\right]>10$. Positively charged clusters grew on average by $\Delta m / \Delta n=1.05$ and were only observed at sufficiently high $\left[\mathrm{NH}_{3}\right] /\left[\mathrm{H}_{2} \mathrm{SO}_{4}\right]$. The $\mathrm{H}_{2} \mathrm{SO}_{4}$ molecules of these clusters are partially neutralized by $\mathrm{NH}_{3}$, in close resemblance to the acid-base bindings of ammonium bisulfate. Supported by model simulations, we substantiate previous evidence for acid-base reactions being the essential mechanism behind the formation of these clusters under atmospheric conditions and up to sizes of at least $2 \mathrm{~nm}$. Our results also suggest that electrically neutral $\mathrm{NH}_{3}-$ $\mathrm{H}_{2} \mathrm{SO}_{4}$ clusters, unobservable in this study, have generally the same composition as ionic clusters for $\left[\mathrm{NH}_{3}\right] /\left[\mathrm{H}_{2} \mathrm{SO}_{4}\right]$ $>10$. We expect that $\mathrm{NH}_{3}-\mathrm{H}_{2} \mathrm{SO}_{4}$ clusters form and grow also mostly by $\Delta m / \Delta n>1$ in the atmosphere's boundary layer, as $\left[\mathrm{NH}_{3}\right] /\left[\mathrm{H}_{2} \mathrm{SO}_{4}\right]$ is mostly larger than 10 . We compared our results from CLOUD with APi-TOF measurements of $\mathrm{NH}_{3}-\mathrm{H}_{2} \mathrm{SO}_{4}$ anion clusters during new-particle formation in the Finnish boreal forest. However, the exact role of $\mathrm{NH}_{3}-$ $\mathrm{H}_{2} \mathrm{SO}_{4}$ clusters in boundary layer particle formation remains to be resolved.

\section{Introduction}

Atmospheric aerosol particles influence the Earth's radiation balance via aerosol-radiation and aerosol-cloud interactions, the latter effect being one of the largest sources of uncertainty in predicting the current and future climate change (IPCC, 2013). An important source of atmospheric aerosol particles is the formation of molecular clusters from gas-phase precursors (vapors) and their subsequent growth to larger sizes by vapor condensation and other processes. Such new-particle formation gives a potentially large contribution to regional and even global cloud condensation nuclei $(\mathrm{CCN})$ populations (Merikanto et al., 2009; Kerminen et al., 2012; Lee et al., 2013), thereby affecting aerosol-cloud interactions and ultimately climate (Kazil et al., 2010; Makkonen et al., 2012; Ghan et al., 2013). However, the very first steps of the atmo- spheric new-particle formation process are still poorly understood and a subject of ongoing research (Kulmala et al., 2014). An important task in this respect is to find out the factors and underlying mechanisms that determine the initial formation from vapors of molecular clusters and particles smaller than $2 \mathrm{~nm}$ diameter, and how this process varies throughout the atmosphere.

It is still largely unknown which vapors participate in atmospheric new-particle formation. The only compound that certainly plays a major role is sulfuric acid $\left(\mathrm{H}_{2} \mathrm{SO}_{4}\right)$ (Weber et al., 1996; Kulmala et al., 2004b; Kulmala et al., 2006; Riipinen et al., 2007). Together with ubiquitous water vapor $\left(\mathrm{H}_{2} \mathrm{O}\right), \mathrm{H}_{2} \mathrm{SO}_{4}$ is believed to be the main source of new particles in the middle and upper troposphere (Lovejoy et al., 2004). However, most measurements of newparticle formation have been made close to the ground, and these particle formation events have been observed to be confined into the lower tropospheric boundary layer (Kulmala et al., 2004b; Kulmala and Kerminen, 2008; O'Dowd et al., 2009; Schobesberger et al., 2013b). Within this relatively warm boundary layer, $\mathrm{H}_{2} \mathrm{SO}_{4}$ alone cannot explain either the particle formation rate or the subsequent growth rate; $\mathrm{H}_{2} \mathrm{SO}_{4}$ concentrations are too low, typically below one part per trillion by volume $(<1 \mathrm{pptv}$, corresponding to $2.5 \times 10^{7}$ molecules $\mathrm{cm}^{-3}$ ) (Kirkby et al., 2011). Other compounds are thus believed to participate in the process of newparticle formation by stabilizing $\mathrm{H}_{2} \mathrm{SO}_{4}$ molecules during the formation of initial clusters (e.g., Petäjä et al., 2011; Sipilä et al., 2010). Candidate compounds for facilitating such stabilization are ions (Lovejoy et al., 2004; Kirkby et al., 2011), bases such as ammonia $\left(\mathrm{NH}_{3}\right)$ (Coffman and Hegg, 1995; Hanson and Eisele, 2002; Ortega et al., 2008; Kirkby et al., 2011) and amines (Kurtén et al., 2008; Paasonen et al., 2012; Almeida et al., 2013), and a possibly wide range of oxygenated organic molecules (Kulmala et al., 1998; Zhang et al., 2004; Metzger et al., 2010; Schobesberger et al., 2013a; Ehn et al., 2014; Riccobono et al., 2014).

Ammonia $\left(\mathrm{NH}_{3}\right)$ and its stabilizing effect on the $\mathrm{H}_{2} \mathrm{SO}_{4}-$ $\mathrm{H}_{2} \mathrm{O}$ system is probably the most thoroughly researched among all those alternatives. The saturation vapor pressure of $\mathrm{H}_{2} \mathrm{SO}_{4}$ is several orders of magnitude lower above bulk $\mathrm{H}_{2} \mathrm{SO}_{4}-\mathrm{H}_{2} \mathrm{O}-\mathrm{NH}_{3}$ solutions compared to $\mathrm{H}_{2} \mathrm{SO}_{4}-\mathrm{H}_{2} \mathrm{O}$ solutions (Marti et al., 1997). The addition of $\mathrm{NH}_{3}$ vapor to a system of $\mathrm{H}_{2} \mathrm{O}$ and $\mathrm{H}_{2} \mathrm{SO}_{4}$ vapors leads to a large enhancement of the rates of aerosol particle formation (Ball et al., 1999; Kirkby et al., 2011). On the molecular scale, investigations of negatively charged $\mathrm{H}_{2} \mathrm{SO}_{4}$ and $\mathrm{NH}_{3}-\mathrm{H}_{2} \mathrm{SO}_{4}$ clusters obtained by ionizing neutral clusters showed that the $\mathrm{NH}_{3}$-containing clusters can form more readily (specifically at warmer temperatures) than pure $\mathrm{H}_{2} \mathrm{SO}_{4}$ clusters (Eisele and Hanson, 2000; Hanson and Eisele, 2002). Theoretical ab initio studies show that $\mathrm{NH}_{3}$ forms strong bonds with $\mathrm{H}_{2} \mathrm{SO}_{4}$, greatly enhancing the stability of $\mathrm{H}_{2} \mathrm{SO}_{4}$-containing clusters, for both electrically neutral and charged clusters (e.g., Kurtén et al., 2007b; Ortega et al., 2008; DePalma et 
al., 2012; Ortega et al., 2012). Generally, these studies predict a maximum base : acid ratio of $1: 1$; however, the maximum cluster size is usually computationally limited, e.g., to up to about 8 molecules in Ortega et al. (2014) or to about 20 molecules in DePalma et al. (2012). Experimentally, small ion clusters of the types $\left(\mathrm{NH}_{3}\right)_{m} \cdot\left(\mathrm{H}_{2} \mathrm{SO}_{4}\right)_{n} \cdot \mathrm{HSO}_{4}^{-}$ and $\left(\mathrm{NH}_{3}\right)_{m} \cdot\left(\mathrm{H}_{2} \mathrm{SO}_{4}\right)_{n} \cdot \mathrm{NH}_{4}^{+}$, containing up to about 15 molecules, have been produced in various laboratory setups, allowing studies of their formation and stability (Hanson and Eisele, 2002; Bzdek et al., 2011; Froyd and Lovejoy, 2012). Ratios $m / n \leq 1$ were observed, in agreement with the theoretical expectations.

Experiments at the Cosmics Leaving OUtdoor Droplets (CLOUD) facility at CERN addressed new-particle formation from $\mathrm{NH}_{3}, \mathrm{H}_{2} \mathrm{SO}_{4}$ and $\mathrm{H}_{2} \mathrm{O}$ in an aerosol chamber setup. The results from these experiments connected the same $\left(\mathrm{NH}_{3}\right)_{m} \cdot\left(\mathrm{H}_{2} \mathrm{SO}_{4}\right)_{n} \cdot$ ion ${ }^{ \pm}$clusters directly to new-particle formation at atmospherically relevant rates (Kirkby et al., 2011). Formation rates comparable to those in the ambient atmosphere were only obtained when either $\mathrm{H}_{2} \mathrm{SO}_{4}$ concentrations were at least 1 order of magnitude higher than typical ambient concentrations, or when the temperature was very low $\left(-25^{\circ} \mathrm{C}\right)$, ruling out $\mathrm{NH}_{3}, \mathrm{H}_{2} \mathrm{SO}_{4}$ and $\mathrm{H}_{2} \mathrm{O}$ as the sole participants in new-particle formation in most regions of the atmospheric boundary layer.

Clusters of $\mathrm{NH}_{3}, \mathrm{H}_{2} \mathrm{SO}_{4}$ and $\mathrm{H}_{2} \mathrm{O}$ may nevertheless play an important role in the very first steps of new-particle formation in the atmosphere. It was recently shown that a critical step may be the stabilization of small $\mathrm{H}_{2} \mathrm{SO}_{4}$-containing clusters by $\mathrm{NH}_{3}$, amines or organic compounds (Kulmala et al., 2013). In that study, these stabilized clusters grew relatively slowly up to an activation size $(1.5-1.9 \mathrm{~nm}$ mobility diameter), and were only then able to grow faster by the enhanced uptake of additional compounds (likely organics). Indeed, the only clusters that have so far been unambiguously identified in the atmosphere and directly linked to newparticle formation are clusters of $\mathrm{H}_{2} \mathrm{SO}_{4}$ plus $\mathrm{NH}_{3}$ or amines or both (Ehn et al., 2010; Zhao et al., 2011; Kulmala et al., 2013).

Gaseous $\mathrm{NH}_{3}$ concentrations vary widely in the atmosphere, both with location and time, from $<10 \mathrm{pptv}$ to several parts per billion by volume (Ziereis and Arnold, 1986; Janson et al., 2001; Riipinen et al., 2007; Gong et al., 2011; Osada et al., 2011). The lower limit is uncertain; low concentrations of $\mathrm{NH}_{3}$ or other bases, such as amines, remain challenging to measure accurately in the atmosphere (e.g., Chang et al., 2003; Huang et al., 2009; von Bobrutzki et al., 2010; VandenBoer et al., 2011). However, recent laboratory experiments have shown a great enhancement of the formation of particles from $\mathrm{H}_{2} \mathrm{SO}_{4}$ by the addition of only tens of parts per trillion by volume of $\mathrm{NH}_{3}$ (Kirkby et al., 2011) or just a few parts per trillion by volume of dimethylamine (Almeida et al., 2013). Therefore, amines are likely to be important for atmospheric particle formation in regions near to amine sources. It remains to be determined which base is the dominant stabilizer of $\mathrm{H}_{2} \mathrm{SO}_{4}$-containing clusters in the atmospheric boundary layer. Some theoretical studies suggest that the stabilizing effect of $\mathrm{NH}_{3}$ dominates for typical atmospheric conditions due to relatively low gas-phase amine concentrations (Nadykto et al., 2011). Indeed, a dominant role for $\mathrm{NH}_{3}$ is consistent with the observation that clusters during new-particle formation in the boreal forest contain more $\mathrm{NH}_{3}$ than dimethylamine (Schobesberger et al., 2013a). Another experimental study reported on the important role of small bases in new-particle formation in Mexico City and Atlanta (Chen et al., 2012). The stabilizing effect due to $\mathrm{NH}_{3}$ could not be differentiated from the effect due to amines, but $\mathrm{NH}_{3}$ concentrations were found to clearly exceed amine concentrations.

This paper presents a comprehensive set of observations of clusters containing mainly $\mathrm{H}_{2} \mathrm{SO}_{4}$ and $\mathrm{NH}_{3}$ during newparticle formation experiments at the CLOUD facility at CERN. These are growing ion clusters, negatively or positively charged, that directly lead to the formation of aerosol particles in the CLOUD aerosol chamber (Kirkby et al., 2011; Keskinen et al., 2013). The chamber features precise control of experimental parameters and exceptional cleanliness. It provides environments with very low levels of contaminants (Schnitzhofer et al., 2014) and allows for the exploration of a wide range of conditions including very low concentrations of critical trace vapors such as $\mathrm{NH}_{3}$ and amines.

The main goal of this work is to provide a comprehensive picture of the role of $\mathrm{NH}_{3}$ in the initial cluster formation, and subsequent new-particle formation, in the $\mathrm{NH}_{3}-\mathrm{H}_{2} \mathrm{SO}_{4}-\mathrm{H}_{2} \mathrm{O}$ system. The specific scientific questions we aim to answer here include the following: (1) what is the detailed molecular structure of the observed clusters under different atmospherically relevant conditions? (2) What are the roles of $\mathrm{NH}_{3}$ and $\mathrm{H}_{2} \mathrm{SO}_{4}$ concentrations and temperature in determining the cluster composition, and thereby the plausible cluster formation mechanism, especially at the limits of low and high $\mathrm{NH}_{3}$ to $\mathrm{H}_{2} \mathrm{SO}_{4}$ gas concentration ratios? And (3) how are the clusters affected by trace amounts of other bases, such as amines, that are usually present as contaminants in experimental systems? We will also discuss the role of different charge carriers involved in these kinds of cluster measurements, and compare our observations with field observations and theoretical expectations. We approached the problem by investigating both negatively and positively charged ions and ion clusters up to $3300 \mathrm{Th}$, corresponding to up to about $2.1 \mathrm{~nm}$ in mobility-equivalent diameter, by using a high-resolution ion mass spectrometer. Our experimental conditions ranged from -25 to $+20^{\circ} \mathrm{C}$ for temperature, $21 \%$ to $90 \%$ for relative humidity $(\mathrm{RH}),<5 \mathrm{pptv}$ to $>1 \mathrm{ppbv}$ for $\mathrm{NH}_{3}$ mixing ratio, and $3.3 \times 10^{6}$ to $1.4 \times 10^{9} \mathrm{~cm}^{-3}$ (corresponding to 0.1 to $56 \mathrm{pptv}$ ) for $\mathrm{H}_{2} \mathrm{SO}_{4}$ concentration. 


\section{Methods}

The results presented here are based on the CLOUD 2 (June and July 2010) and CLOUD 3 (October and November 2010) campaigns at the CLOUD chamber at CERN.

\subsection{The CLOUD chamber}

A description of the general experimental setup is given in more detail in Kirkby et al. (2011). The CLOUD chamber is a cylindrical stainless-steel container with an inner volume of $26.1 \mathrm{~m}^{3}$. It is filled principally with air $(79 \%$ nitrogen, $21 \%$ oxygen) that is obtained from the evaporation of cryogenic liquids, with selected additional trace gases. Ozone $\left(\mathrm{O}_{3}\right)$ concentrations in the chamber typically range from 200 to $1000 \mathrm{ppbv}$. RH typically varies between $21 \%$ and $90 \%$, but is mostly held fixed between $37 \%$ and $41 \%$. The trace gases sulfur dioxide $\left(\mathrm{SO}_{2}\right)$ and $\mathrm{NH}_{3}$ are added on demand via individual independent lines. Fresh, humidified air and trace gases are fed into the chamber continuously at a total rate of $85 \mathrm{~L} \mathrm{~min}^{-1}$, while air is extracted by the measuring instruments. The desired concentration of each gas is achieved by continuous constant injection at the appropriate flow rate. The chamber is usually operated at an overpressure of 5 mbar to avoid contamination from outside the chamber. A pair of fans facilitate the mixing of the chamber contents (Voigtländer et al., 2012). The inside of the chamber is irradiated on demand by UV light from the top of the chamber (Kupc et al., 2011). This UV light induces photolytic reactions, in particular the oxidation of $\mathrm{SO}_{2}$ (at concentrations of 15 to $34 \mathrm{ppbv}$ ) to form $\mathrm{H}_{2} \mathrm{SO}_{4}$. The temperature inside the chamber is actively controlled and stable within $0.01^{\circ} \mathrm{C}$ for the typical length of an experiment.

Some ionization always occurs inside the chamber via natural galactic cosmic rays. In addition, the chamber can be exposed to $3.5 \mathrm{GeV} / \mathrm{c}$ pions $\left(\pi^{+}\right)$that are provided by the CERN Proton Synchrotron in one to three spills per minute. The intensity of the spills can be regulated, and the mean total ion pair production rate in the chamber is therefore adjustable between $2 \mathrm{~cm}^{-3} \mathrm{~s}^{-1}$ ( $\pi^{+}$beam off) and $42 \mathrm{~cm}^{-3} \mathrm{~s}^{-1}$ (at the usual maximum available $\pi^{+}$beam intensity). An electrical clearing field of $20 \mathrm{kV} \mathrm{m}^{-1}$ can be applied by means of a pair of field cage electrodes, mounted at the top and the bottom of the chamber. This field will sweep out all ions in the chamber in about $1 \mathrm{~s}$, providing an environment practically free of ions, when needed.

During the CLOUD 2 and CLOUD 3 campaigns, a wide array of instruments was arranged around the chamber, continuously analyzing its contents via 16 sampling probes. These sampling probes were mounted radially around the chamber and projected $0.5 \mathrm{~m}$ into the chamber. The instrumentation included an atmospheric pressure interface timeof-flight (APi-TOF) mass spectrometer to measure the chemical composition of ions (up to about $2 \mathrm{~nm}$ in size). Results from the APi-TOF are the main subject of this study, and

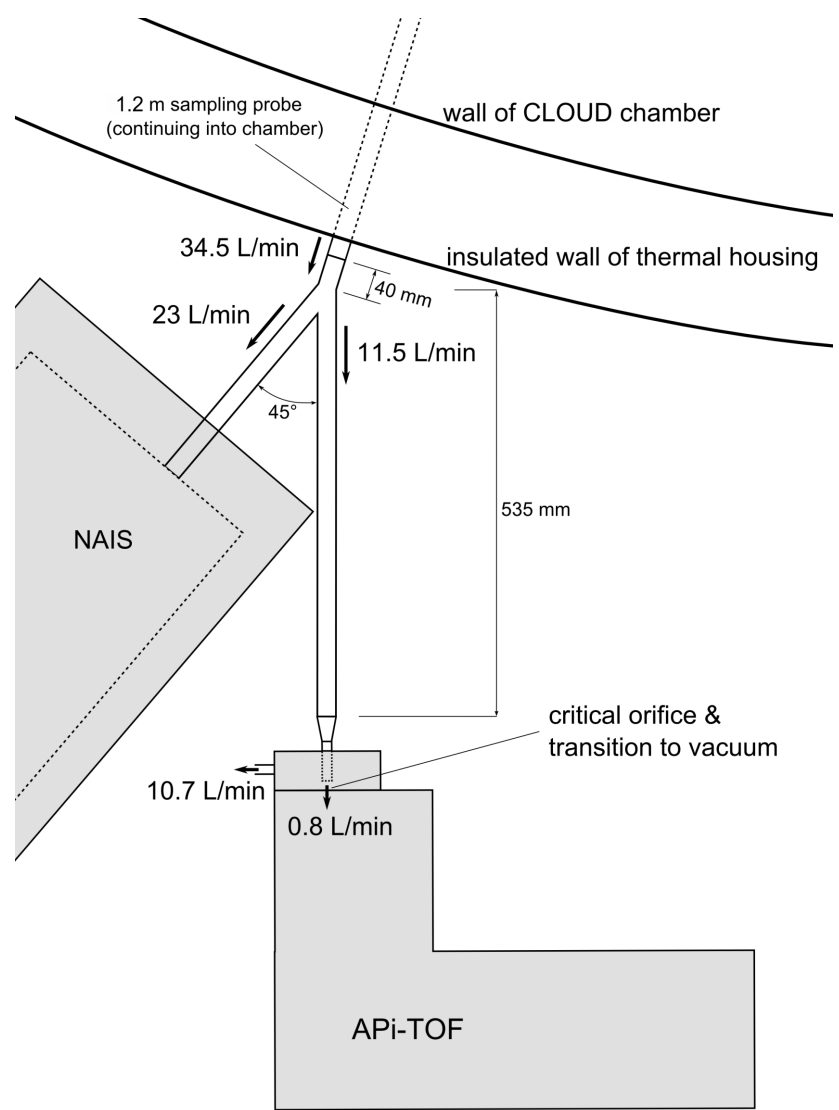

Figure 1. Setup of the APi-TOF at the CLOUD chamber during the CLOUD 2 and CLOUD 3 campaigns. The APi-TOF shared one sampling probe $(22.1 \mathrm{~mm}$ ID) with the NAIS. The flow was split via a Y-splitter. Before reaching the critical orifice inlet of the APiTOF, the inner tube diameter reduced from the Y-splitter's $21.2 \mathrm{~mm}$ to $7 \mathrm{~mm}$.

the instrument is described below. The rest of the instrumentation included an Airborne Neutral cluster and Air Ion Spectrometer (NAIS) (Mirme et al., 2010), used to measure ions from 0.8 to $40 \mathrm{~nm}$ in mobility-equivalent diameter. A comprehensive suite of particle counting and sizing instruments facilitated aerosol number size distribution measurements, covering the range from 1.3 to $100 \mathrm{~nm}$ (Kirkby et al., 2011). A chemical ionization mass spectrometer (CIMS) (Kürten et al., 2011, 2012) measured $\mathrm{H}_{2} \mathrm{SO}_{4}$ concentrations down to about $10^{5} \mathrm{~cm}^{-3}\left(4 \times 10^{-3} \mathrm{pptv}\right)$ at an accuracy of $+100 \% /-50 \%$. During CLOUD 3 only, a proton transfer reaction mass spectrometer (PTR-MS) (Norman et al., 2007) and a LOng Path Absorption Photometer (LOPAP) (Bianchi et al., 2012) were used to measure $\mathrm{NH}_{3}$ concentrations down to $35 \mathrm{pptv}$. 


\subsection{Setup of the APi-TOF at the CLOUD chamber}

The APi-TOF sampled air from the CLOUD chamber using one of the radially mounted sampling probes. The sampling probe's inner diameter (ID) was $22.1 \mathrm{~mm}$ and its total length was $1.2 \mathrm{~m}$, of which $0.5 \mathrm{~m}$ projected into the chamber. The APi-TOF shared the same sampling probe with the NAIS. The total sample flow from the chamber of $27.8 \mathrm{~L} \mathrm{~min}^{-1}$ (at $-24^{\circ} \mathrm{C}$ ) to $34.5 \mathrm{~L} \mathrm{~min}^{-1}$ (at $19^{\circ} \mathrm{C}$ ) was split at $45^{\circ}$ using a Ysplitter (Fig. 1). The flow from the Y-splitter to the APi-TOF (9.8 to $11.5 \mathrm{~L} \mathrm{~min}^{-1}$ ) was directed at the APi-TOF's orifice inlet, where $0.8 \mathrm{~L} \mathrm{~min}^{-1}$ was drawn into the instrument and the rest discarded.

Figure 1 shows that much of the sampling line was exposed to room temperature $\left(>5^{\circ} \mathrm{C}\right)$. We thermally insulated the lines using Armaflex pipe insulation with aluminum tape on the outside, to minimize unwanted heating of the air taken from the chamber. The $0.8 \mathrm{~L} \mathrm{~min}^{-1}$ sample drawn into the APi-TOF was taken from the center of a $\sim 10 \mathrm{~L} \mathrm{~min}^{-1}$ flow, further mitigating heating of the sample. Simulations of the heat flux from warm ambient air into cool air flowing in a tube, insulated by a jacket of air, indicate that the APi-TOF sample may be heated up to several degrees before reaching the APi-TOF (e.g., from -25 to $-16.5^{\circ} \mathrm{C}$ or from 5 to $8.5^{\circ} \mathrm{C}, \pm 2{ }^{\circ} \mathrm{C}$, at a room temperature of $20^{\circ} \mathrm{C}$ ). However, such heating would not qualitatively influence the conclusions regarding temperature effects in this study. In fact, it would only reduce the magnitude of the observed temperature effects.

\subsection{The APi-TOF}

The APi-TOF is a time-of-flight mass spectrometer built by Tofwerk AG and Aerodyne Research, Inc. A detailed description of the instrument and its capabilities is found in Junninen et al. (2010). The APi-TOF is designed to measure the mass-to-charge ratio of ambient ions of either positive or negative polarity. No ionization of the sample is performed, so only ions that are formed in the CLOUD chamber are detected. Air is sampled directly from atmospheric pressure via a critical orifice. In the interface (APi), ions are focused and guided through differentially pumped chambers to the timeof-flight mass spectrometer (TOF), where the pressure is reduced to $10^{-6}$ mbar.

During CLOUD 2 and CLOUD 3, the mass accuracy was better than $10 \mathrm{ppm}$. The resolving power (determined from the peak width at half maximum) was up to $4900 \mathrm{Th} / \mathrm{Th}$ (CLOUD 2) or up to $5300 \mathrm{Th} / \mathrm{Th}$ (CLOUD 3) for negative ions, and up to $4300 \mathrm{Th} / \mathrm{Th}$ for positive ions. The instrument was set to obtain mass-to-charge ratios up to either about $2115 \mathrm{Th}$ (in positive mode and some experiments in negative mode) or $3300 \mathrm{Th}$ (most experiments in negative mode). At all times during these measurements, the APi-TOF detected only singly charged ions; therefore, the unit thomson (Th) can also be thought of as atomic mass unit (u) or dal- ton $(\mathrm{Da})$. To provide a comparison with condensation particle counters and mobility spectrometers, a singly charged ammonium bisulfate cluster ion at $3300 \mathrm{Th}$ corresponds to about $2.1 \mathrm{~nm}$ in mobility-equivalent diameter, using the conversion procedure described by Ehn et al. (2011). The APiTOF's ion transmission efficiency was set to have its maximum at about 900 to $1400 \mathrm{Th}$ for negative ions, and at about 100 to $300 \mathrm{Th}$ for positive ions. In the CLOUD campaigns, we recorded spectra at a time resolution of $5 \mathrm{~s}$. The signalto-noise ratio usually resulted in a maximum practical time resolution of $30 \mathrm{~s}$.

Sampled ions may be subject to fragmentation inside the APi-TOF. Such fragmentation was mainly manifest by the usual near-absence of any $\mathrm{H}_{2} \mathrm{O}$ clustered with, for instance, sulfuric acid. The evaporation rate of $\mathrm{H}_{2} \mathrm{O}$ from these clusters is too rapid to survive detection in the non-equilibrium environment of the APi-TOF. However, many more strongly bound clusters can be detected, as will be shown here and has been shown before (e.g., Ehn et al., 2010; Junninen et al., 2010). Also, comparisons with ion mobility spectrometers demonstrated a good agreement with the APi-TOF's results (Ehn et al., 2011; Schobesberger et al., 2013a). Comparisons between the APi-TOF and the NAIS for our measurements produced a fair agreement as well, so the ion mass spectra obtained by the APi-TOF are, in general, representative of the actual population of small ions and ion clusters. However, a few molecules other than $\mathrm{H}_{2} \mathrm{O}$ may also be lost from some clusters during the sampling, as has also been suggested by comparisons between APi-TOF results and cluster simulations (Olenius et al., 2013b; Ortega et al., 2014).

The data obtained from the APi-TOF measurements were processed and analyzed using tofTools, a software package based on MATLAB and under continuous development, mainly at the University of Helsinki. Details on the analysis of APi-TOF data are found elsewhere (Schobesberger et al., 2013a).

\subsection{Gas-phase concentrations of $\mathrm{NH}_{3}$}

The primary means of obtaining the gas-phase concentration of $\mathrm{NH}_{3}\left(\left[\mathrm{NH}_{3}\right]\right)$ were the results from the LOPAP (Bianchi et al., 2012). It was only available during CLOUD 3 and above $0{ }^{\circ} \mathrm{C}$. Below $0{ }^{\circ} \mathrm{C}$, measurements of $\left[\mathrm{NH}_{3}\right]$ are available from the PTR-MS for some experiments in CLOUD 3. Ammonia concentrations could also be estimated from the calibrated mass flow controller settings.

In practice, $\left[\mathrm{NH}_{3}\right]$ was directly measured whenever $\mathrm{NH}_{3}$ had been added during most of the CLOUD 3 campaign. Without the deliberate addition of $\mathrm{NH}_{3}$, values of $\left[\mathrm{NH}_{3}\right]$ were below the detection limit of $35 \mathrm{pptv}$. More refined measurements during later campaigns showed that the contaminant level of $\left[\mathrm{NH}_{3}\right]$ was in fact likely $<2$ pptv for experiments at $5{ }^{\circ} \mathrm{C}$ (Almeida et al., 2013). The most plausible source of this contaminant $\mathrm{NH}_{3}$ was evaporation from the inside walls of the chamber. Therefore, we assumed that con- 
taminant levels of $\left[\mathrm{NH}_{3}\right]$ were $2 \mathrm{pptv}$ at $5{ }^{\circ} \mathrm{C}$ and directly proportional to the desorption rate of $\mathrm{NH}_{3}$, assuming an activation energy of $33 \mathrm{~kJ} \mathrm{~mol}^{-1}$. Thus calculated contaminant levels of $\left[\mathrm{NH}_{3}\right]$ ranged from $0.4 \mathrm{pptv}$ (at $-24.7^{\circ} \mathrm{C}$ ) to $4.1 \mathrm{pptv}$ (at $19.8^{\circ} \mathrm{C}$ ).

Ammonia concentrations also had to be calculated for a selection of experiments below $0{ }^{\circ} \mathrm{C}$ when no direct measurement results of $\left[\mathrm{NH}_{3}\right]$ were available. In the beginning of these experiments, $\left[\mathrm{NH}_{3}\right]$ was above contaminant levels, but no $\mathrm{NH}_{3}$ was being added to the chamber. Therefore, a decay of $\left[\mathrm{NH}_{3}\right]$ as measured previously by the LOPAP was used for our calculations, in addition to the proportionality to the desorption rate.

During the few experiments when $\mathrm{NH}_{3}$ was added during CLOUD 2, estimates for $\left[\mathrm{NH}_{3}\right]$ were made using the settings of the mass flow controllers that control the gas flows into and out of the CLOUD chamber.

\subsection{Ambient measurements in the boreal forest}

The same APi-TOF as in the CLOUD campaigns was deployed also at the Station for Measuring EcosystemAtmosphere Relations (SMEAR II) (Hari and Kulmala, 2005), where it measured negatively charged ions during spring 2011. The SMEAR II station is located in Hyytiälä, southern Finland, within a boreal forest. Tampere (population 213000) is the closest larger town, 50-60 km southwest of the station. The station is the site of a host of continuing atmospheric observations, which includes extensive aerosol measurements that can be used to detect and analyze newparticle formation events (Kulmala et al., 2004a). For the results shown in this study, $\left[\mathrm{NH}_{3}\right]$ was measured by a Monitoring instrument for Aerosols and Gases (MARGA) (Makkonen et al., 2014), and $\left[\mathrm{H}_{2} \mathrm{SO}_{4}\right]$ was measured by a CIMS, similar to the one used at the CLOUD experiments.

The APi-TOF was situated inside a container in the forest, directly sampling ambient air in a setup similar to that used at the CLOUD chamber (details in Schobesberger et al., 2013a). It should be noted that the APi-TOF was tuned differently for those measurements, resulting in a reduced ion transmission efficiency at high $m / z$ compared to the experiments at CLOUD.

\section{Results}

\subsection{Negatively charged ions during new-particle formation experiments from $\mathrm{H}_{2} \mathrm{SO}_{4}$ (no $\mathrm{NH}_{3}$ added)}

During the CLOUD 2 and 3 campaigns, the conditions in the CLOUD chamber were set to precisely maintained conditions, specifically to a temperature of typically either 5 or $19-20{ }^{\circ} \mathrm{C}$, an $\mathrm{RH}$ of typically $37 \%$ to $41 \%$, an $\mathrm{SO}_{2}$ concentration between 15 and $34 \mathrm{ppbv}$, and an $\mathrm{O}_{3}$ concentration between 200 and 1000 ppbv. In the initial experiments, no $\mathrm{NH}_{3}$ was fed into the chamber.

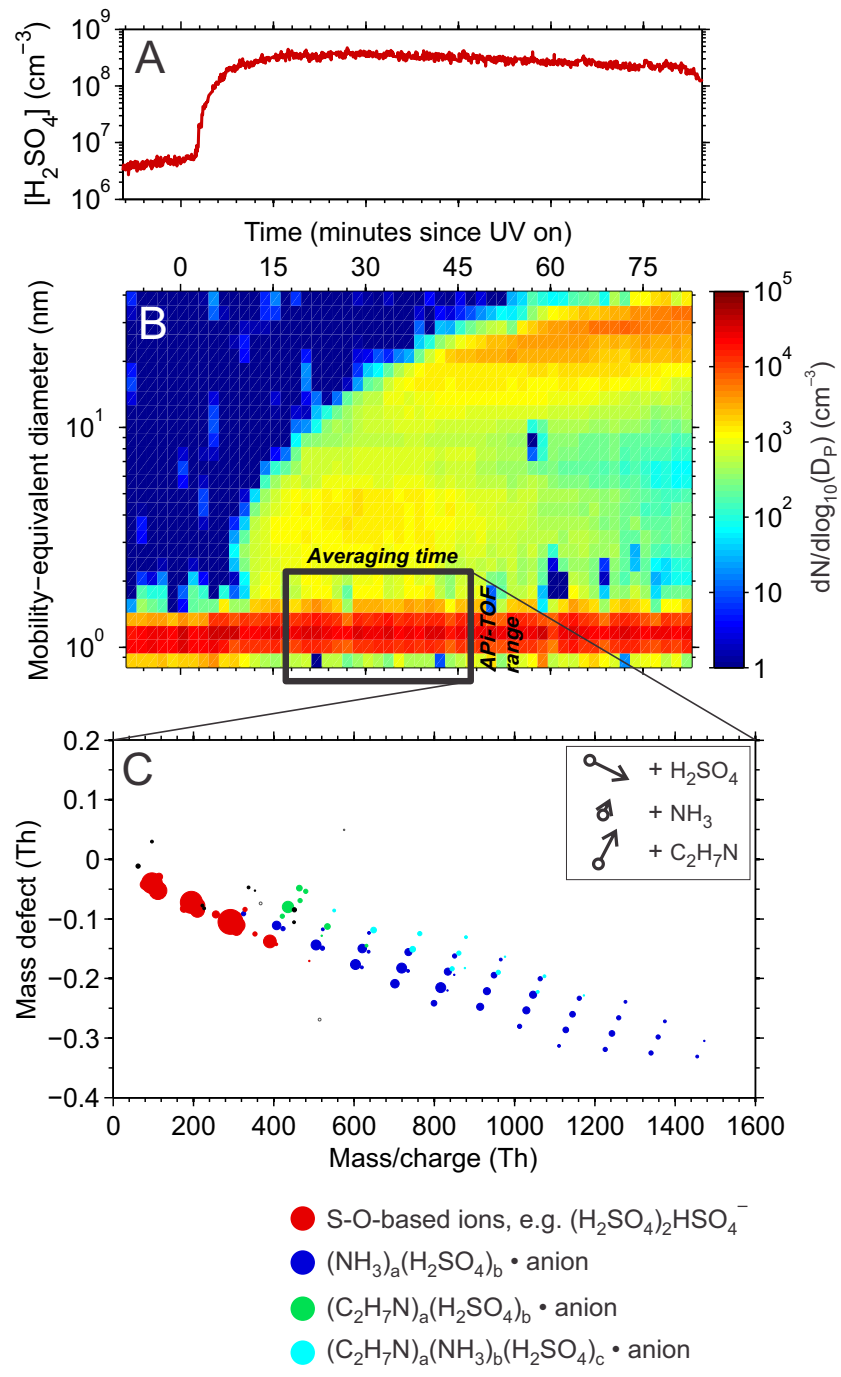

Figure 2. Summary of a typical new-particle formation experiment in the CLOUD chamber during the CLOUD 2 campaign, with no added $\mathrm{NH}_{3}$, at $20^{\circ} \mathrm{C}, 60 \%$ relative humidity, $3.7 \times 10^{8} \mathrm{~cm}^{-3}$ $\left[\mathrm{H}_{2} \mathrm{SO}_{4}\right]$ (15 pptv), estimated $4 \mathrm{pptv}\left[\mathrm{NH}_{3}\right]$ (none added), < $1 \mathrm{pptv}$ $\left[\mathrm{C}_{2} \mathrm{H}_{7} \mathrm{~N}\right]$, pion beam on. (a) Measurements of sulfuric acid concentration $\left(\left[\mathrm{H}_{2} \mathrm{SO}_{4}\right]\right)$ by CIMS, showing the marked increase in $\left[\mathrm{H}_{2} \mathrm{SO}_{4}\right]$ after the start of UV illumination. (b) Consequent newparticle formation event as observed by the NAIS negative ion channel, showing negatively charged ions that grow from originally well below $2 \mathrm{~nm}$ to larger sizes. The black box marks the time period of steady new-particle formation that was used for averaging APiTOF data, and the size range covered by the APi-TOF mass spectra. (c) Mass defect diagram for the APi-TOF mass spectrum, averaged over the shown particle formation event. The diagram reveals the composition of the growing negatively charged ions between about 1 and $2 \mathrm{~nm}$. These are ion clusters, growing by the addition of $\mathrm{H}_{2} \mathrm{SO}_{4}$ and contaminant $\mathrm{NH}_{3}$ molecules (red and blue). Some clusters also contain contaminant amines (green and light blue). 
A typical new-particle formation experiment in the CLOUD chamber was initiated by the UV lights being turned on, leading to a marked increase of $\left[\mathrm{H}_{2} \mathrm{SO}_{4}\right]$ (Fig. 2a), which in turn triggered new-particle formation. The formation and subsequent growth of particles was measured by the particle or ion counting and sizing instrumentation, including the NAIS (Fig. 2b). For most of the investigated gas mixtures, the NAIS showed that ion-induced nucleation proceeded only or predominantly in negative polarity. Therefore the APi-TOF was mostly run in the negative mode (for detecting negatively charged ions) during both campaigns. Naturally, the main focus of this study also lies on negatively charged ions.

The APi-TOF measurements provide high-resolution mass spectra of ions and ion clusters up to about $2.1 \mathrm{~nm}$ in mobility-equivalent diameter, capturing exactly the critical first steps of the ion-induced pathway of new-particle formation (illustrated in Fig. 2b). The elemental compositions of ions are identified primarily by their exact mass. Therefore, it is advantageous to present mass spectra as mass defect diagrams (Fig. 2c). In such a diagram, the mass defect for each ion (i.e., the deviation from its nominal mass) is plotted against its mass-to-charge ratio. Any given ion will occupy a unique position in this diagram, and an addition of a specified atom or molecule will move an ion by a characteristic vector (e.g., see Fig. 2c insert).

Note that the APi-TOF spectra shown and analyzed in this study are averages over the duration of the steady-state conditions during a new-particle formation experiment (illustrated in Fig. 2). The steady-state periods were defined as the period during which no change in the APi-TOF ion spectrum occurred. Their duration ranged from $200 \mathrm{~s}$ to over $6 \mathrm{~h}$.

The new-particle formation experiments in the CLOUD chamber covered a range in $\left[\mathrm{H}_{2} \mathrm{SO}_{4}\right]$ levels from $3.3 \times 10^{6}$ to $1.4 \times 10^{9}$ molecules $\mathrm{cm}^{-3}$ (0.1 to $\left.56 \mathrm{pptv}\right)$. During a typical experiment, the dominant negatively charged ions were small sulfuric acid anion clusters, with the strongest signal, in most cases, from the trimer, $\left(\mathrm{H}_{2} \mathrm{SO}_{4}\right)_{2} \cdot \mathrm{HSO}_{4}^{-}$(Fig. 2c). Heavier ion clusters ( $>350 \mathrm{Th}$; containing $>3$ sulfur atoms) were considerably less abundant for most experimental conditions. These heavier clusters consisted mostly of $\mathrm{H}_{2} \mathrm{SO}_{4}$ molecules. However, they were observed not only as "pure" sulfuric acid clusters but also as clusters with base molecules, specifically molecules of $\mathrm{NH}_{3}$ or of various organic bases, mainly amines.

In general, larger clusters contained more base molecules. The predominant base in these clusters was $\mathrm{NH}_{3}$, yielding clusters of the form $\left(\mathrm{NH}_{3}\right)_{m} \cdot\left(\mathrm{H}_{2} \mathrm{SO}_{4}\right)_{n} \cdot \mathrm{HSO}_{4}^{-}$(Fig. 2c). Only certain numbers of $\mathrm{NH}_{3}$ molecules $(m)$ were seen for each number of $\mathrm{H}_{2} \mathrm{SO}_{4}$ molecules $(n)$, depending on experimental conditions. This dependency will be discussed below in more detail. Note that neither $\mathrm{NH}_{3}$ nor amines had been deliberately fed into the chamber for these experiments. Instead, they were unintended impurities.

Some of the negatively charged clusters that grew by the addition of $\mathrm{H}_{2} \mathrm{SO}_{4}$ and base molecules had an additional oxy- gen atom (Fig. 2c). This can be explained by the growth starting from $\mathrm{HSO}_{5}^{-}$instead of $\mathrm{HSO}_{4}^{-}$. The role of $\mathrm{HSO}_{5}^{-}$, as opposed to $\mathrm{HSO}_{4}^{-}$, in the composition and growth of ion clusters, as well as its origin, will be described and discussed in Sects. 3.2 and 4.2.

Note that the APi-TOF did not detect any growing positively charged clusters under the typical experimental conditions discussed in this section; that is, when no $\mathrm{NH}_{3}$ was fed into the chamber, temperature was either 5 or $19^{\circ} \mathrm{C}$ and RH was $40 \%$. This is consistent with simultaneous NAIS measurements, which did not show any growth starting from small positively charged ions $(<2.5 \mathrm{~nm})$.

\subsection{Charge carriers different from $\mathrm{HSO}_{4}^{-}$}

Practically all anion clusters that included the bisulfate ion $\left(\mathrm{HSO}_{4}^{-}\right)$were also observed in the form where $\mathrm{HSO}_{4}^{-}$was replaced either with $\mathrm{HSO}_{5}^{-}$or, to a lesser extent, with $\mathrm{SO}_{5}^{-}$. The $\mathrm{HSO}_{5}^{-}$and $\mathrm{SO}_{5}^{-}$ions appear to be less efficient than $\mathrm{HSO}_{4}^{-}$ in forming the initial clusters with $\mathrm{H}_{2} \mathrm{SO}_{4}$ molecules, based on the observed ratios of anion sulfuric-acid dimer signals to those of the bare anion, i.e.:

$$
\begin{aligned}
& {\left[\mathrm{H}_{2} \mathrm{SO}_{4} \cdot \mathrm{HSO}_{4}^{-}\right] /\left[\mathrm{HSO}_{4}^{-}\right]>\left[\mathrm{H}_{2} \mathrm{SO}_{4} \cdot \mathrm{HSO}_{5}^{-}\right] /\left[\mathrm{HSO}_{5}^{-}\right]} \\
& >\left[\mathrm{H}_{2} \mathrm{SO}_{4} \cdot \mathrm{SO}_{5}^{-}\right] /\left[\mathrm{SO}_{5}^{-}\right] .
\end{aligned}
$$

The concentrations of $\mathrm{HSO}_{5}^{-}$and $\mathrm{SO}_{5}^{-}$in CLOUD were particularly high compared to the concentration of $\mathrm{HSO}_{4}^{-}$ when the concentration of $\mathrm{H}_{2} \mathrm{SO}_{4}$, the dominant precursor of $\mathrm{HSO}_{4}^{-}$, was low. The relative amounts of charge carriers were also affected by the $\pi^{+}$beam intensity (i.e., the total ion concentration) and by the $\mathrm{O}_{3}$ concentration: higher beam intensity led to a higher fraction of $\mathrm{HSO}_{5}^{-}$ions, whereas practically no $\mathrm{HSO}_{5}^{-}$or $\mathrm{SO}_{5}^{-}$was observed in experiments without $\mathrm{O}_{3}$ present in the CLOUD chamber. In addition, the abundance of $\mathrm{HSO}_{5}^{-}$-based ion clusters relative to $\mathrm{HSO}_{4}^{-}$-based clusters in CLOUD increased chiefly together with an increasing role of $\mathrm{NH}_{3}$. In the most extreme case - i.e., high $\left[\mathrm{NH}_{3}\right]$, low $\left[\mathrm{H}_{2} \mathrm{SO}_{4}\right]$ and high beam intensity - about $60 \%$ of the large clusters (those containing 5-19 S atoms) were associated with $\mathrm{HSO}_{5}^{-}$. A maximum of $7 \%$ of the larger clusters were associated with $\mathrm{SO}_{5}^{-}$, and a maximum of $<3 \%$ with $\mathrm{H}_{2} \mathrm{O}_{11} \mathrm{NS}_{2}^{-}$, probably in the form $\mathrm{H}_{2} \mathrm{~S}_{2} \mathrm{O}_{8} \cdot \mathrm{NO}_{3}^{-}$.

The cluster compositions were very similar regardless of which ion carried their charge. The most important difference between the different charge carriers was that we observed $\mathrm{NH}_{3} \cdot\left(\mathrm{H}_{2} \mathrm{SO}_{4}\right)_{2} \cdot \mathrm{HSO}_{5}^{-}$clusters, whereas the smallest ammonia-containing cluster associated with $\mathrm{HSO}_{4}^{-}$was $\mathrm{NH}_{3} \cdot\left(\mathrm{H}_{2} \mathrm{SO}_{4}\right)_{3} \cdot \mathrm{HSO}_{4}^{-}$. The counts for $\mathrm{NH}_{3} \cdot\left(\mathrm{H}_{2} \mathrm{SO}_{4}\right)_{2} \cdot \mathrm{HSO}_{5}^{-}$clusters were usually more than an order of magnitude lower than the counts for similar clusters with one more $\mathrm{H}_{2} \mathrm{SO}_{4}$ molecule, $\mathrm{NH}_{3} \cdot\left(\mathrm{H}_{2} \mathrm{SO}_{4}\right)_{3} \cdot \mathrm{HSO}_{5}^{-}$, whereas the cluster $\mathrm{NH}_{3} \cdot\left(\mathrm{H}_{2} \mathrm{SO}_{4}\right)_{2} \cdot \mathrm{HSO}_{4}^{-}$was totally absent. Subsequently, the average ratio between the number of $\mathrm{NH}_{3}$ molecules $(m)$ and the number of $\mathrm{H}_{2} \mathrm{SO}_{4}$ molecules $(n)$ 
was initially higher in $\mathrm{HSO}_{5}^{-}$-based clusters than in the corresponding $\mathrm{HSO}_{4}^{-}$-based clusters. However, this difference decreased with an increasing cluster size, disappearing or staying approximately constant at about $n \geq 9$. The implications of these observations will be discussed in Sect. 4.2.

\subsection{Contaminant amines in growing anion clusters}

No amines were deliberately added into the chamber for the experiments discussed here, i.e., throughout the CLOUD 2 and CLOUD 3 campaigns. Amine contamination originated probably from the same source as $\mathrm{NH}_{3}$ (see Sect. 2.4). We can give some estimate of the contaminant levels of the dominant amine, $\mathrm{C}_{2} \mathrm{H}_{7} \mathrm{~N}$, based on measurements from later CLOUD campaigns when dimethylamine was also added into the chamber in several experiments (Praplan et al., 2012; Almeida et al., 2013). These estimates are based on direct measurements of dimethylamine concentrations down to $0.2 \mathrm{pptv}$ performed during the later experiments and on measurements of the content of $\mathrm{C}_{2} \mathrm{H}_{7} \mathrm{~N}$ in clusters seen by the APi-TOF. Based on those results, we speculate that gasphase contaminant concentrations of $\mathrm{C}_{2} \mathrm{H}_{7} \mathrm{~N}$ were between 0.1 and 1 pptv during the CLOUD 2 campaign, and about 0.1 pptv or even less during the CLOUD 3 campaign.

In the experiments discussed here, the highest abundance of the clusters containing contaminant organic bases (amines or amides) was usually seen on those clusters that contained a sulfuric acid tetramer anion. Tetramers were observed either without any base, such as $\left(\mathrm{H}_{2} \mathrm{SO}_{4}\right)_{3} \cdot \mathrm{HSO}_{4}^{-}$, clustered with $\mathrm{NH}_{3}$, or clustered with a basic organic compound. The organic base with the highest signal has the formula $\mathrm{C}_{2} \mathrm{H}_{7} \mathrm{~N}$ (dimethylamine or ethylamine). Other bases observed in these clusters were $\mathrm{CH}_{5} \mathrm{~N}$ (methylamine), $\mathrm{CH}_{4} \mathrm{~N}_{2} \mathrm{O}$ (urea) and larger amines or amides (Fig. 3). Note that in some cases, we are unable to resolve whether one oxygen atom was part of the organic constituent or whether the ion was $\mathrm{HSO}_{5}^{-}$instead of $\mathrm{HSO}_{4}^{-} \cdot \mathrm{C}_{2} \mathrm{H}_{7} \mathrm{~N}$ was also seen to be bound to the sulfuric acid trimer anion, forming $\mathrm{C}_{2} \mathrm{H}_{7} \mathrm{~N} \cdot\left(\mathrm{H}_{2} \mathrm{SO}_{4}\right)_{2} \cdot \mathrm{HSO}_{4}^{-}$, although with a signal about 2 orders of magnitude smaller than that of the cluster $\mathrm{C}_{2} \mathrm{H}_{7} \mathrm{~N} \cdot\left(\mathrm{H}_{2} \mathrm{SO}_{4}\right)_{3} \cdot \mathrm{HSO}_{4}^{-}$. Notably, the corresponding cluster with $\mathrm{NH}_{3}$ instead of the amine, $\mathrm{NH}_{3} \cdot\left(\mathrm{H}_{2} \mathrm{SO}_{4}\right)_{2} \cdot \mathrm{HSO}_{4}^{-}$, was not observed, indicating its weaker base nature.

The clusters containing amines (or other organic bases) also evidently grew by the accretion of $\mathrm{H}_{2} \mathrm{SO}_{4}$ and $\mathrm{NH}_{3}$ molecules when amines were present at contaminant levels $\left(\left[\mathrm{C}_{2} \mathrm{H}_{7} \mathrm{~N}\right]<1 \mathrm{pptv}\right)$ : increasingly larger clusters of the type $\mathrm{Y} \cdot\left(\mathrm{NH}_{3}\right)_{m} \cdot\left(\mathrm{H}_{2} \mathrm{SO}_{4}\right)_{n} \cdot \mathrm{HSO}_{4}^{-}$were formed, where $\mathrm{Y}$ was almost always one $\mathrm{N}$-containing organic compound, and at maximum two such compounds $\left(\left(\mathrm{C}_{2} \mathrm{H}_{7} \mathrm{~N}\right)_{2}\right.$ or $\left.\mathrm{CH}_{5} \mathrm{~N} \cdot \mathrm{C}_{2} \mathrm{H}_{7} \mathrm{~N}\right)$. In addition, the fraction of clusters that included $\mathrm{N}$-containing organic compounds was smaller for larger clusters ( $n \geq 4$ ) (Figs. 2c and Fig. 3).

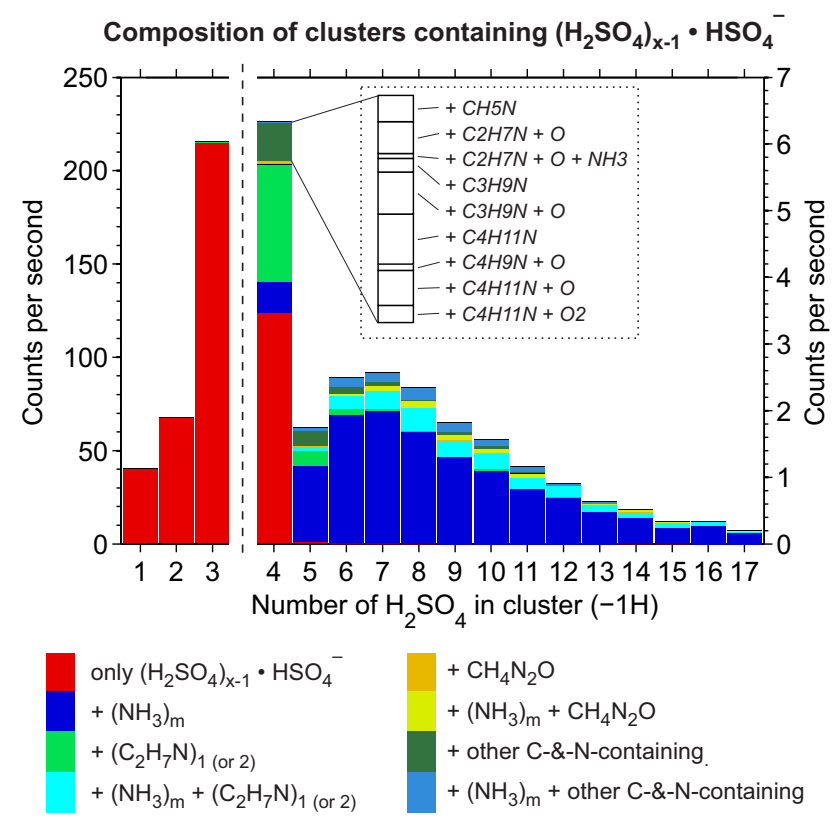

Figure 3. Details on the composition of the growing negatively charged clusters during the new-particle formation experiment presented in Fig. 2, binned by the number $\mathrm{x}$ of $\mathrm{H}_{2} \mathrm{SO}_{4}$ molecules in the cluster. Note that only ion clusters based on the $\mathrm{HSO}_{4}^{-}$ion are shown, for simplicity. However, these ions constitute the majority of all ions, and practically all ions at $\mathrm{x}>3$ (i.e., beyond $350 \mathrm{Th}$, as can be seen in Fig. 2C). Note that besides contaminant $\mathrm{NH}_{3}$, a wide range of contaminant nitrogen-containing organic compounds are seen in these clusters if $x>3$, especially for $x=4$. By far the most observed of these compounds is $\mathrm{C}_{2} \mathrm{H}_{7} \mathrm{~N}$ (dimethylamine or ethylamine). Most likely all these organics are amines or amides (such as $\mathrm{CH}_{4} \mathrm{~N}_{2} \mathrm{O}$, probably urea), their high proton affinities facilitating the formation of clusters with $\mathrm{H}_{2} \mathrm{SO}_{4}$.

\subsection{Composition of $\mathrm{NH}_{3}-\mathrm{H}_{2} \mathrm{SO}_{4}$ clusters under different experimental conditions}

In later experiments, $\mathrm{NH}_{3}$ was deliberately fed into the chamber to investigate new-particle formation over a range of $\left[\mathrm{NH}_{3}\right]$ from contaminant levels (<5 pptv; cf. Sect. 2.4) up to $1090 \mathrm{pptv}$. The range of investigated temperatures reached from +20 down to $-25^{\circ} \mathrm{C}$. (Note the possibility of air sampled from the chamber at low temperatures being heated somewhat before reaching the APi-TOF, cf. Sect. 2.2.)

For all experimental conditions, negative ion clusters with more than 4 or 5 sulfur atoms grew by the accretion of $\mathrm{NH}_{3}$ and $\mathrm{H}_{2} \mathrm{SO}_{4}$ molecules, forming progressively larger $\left(\mathrm{NH}_{3}\right)_{m} \cdot\left(\mathrm{H}_{2} \mathrm{SO}_{4}\right)_{n} \cdot \mathrm{HSO}_{4}^{-}$clusters. The number of $\mathrm{NH}_{3}$ molecules added on average per added $\mathrm{H}_{2} \mathrm{SO}_{4}$ molecule remained nearly constant from 4 or 5 sulfur atoms up to the upper detection limit of about 27 sulfur atoms, within the measurement uncertainties. These findings are illustrated in Fig. 4, which shows the average number of $\mathrm{NH}_{3}$ molecules $(m)$ in clusters containing a certain amount of 


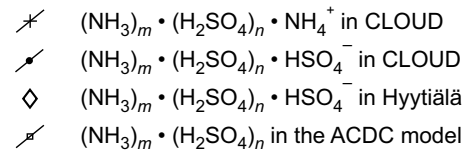

A 19 to $20^{\circ} \mathrm{C}$
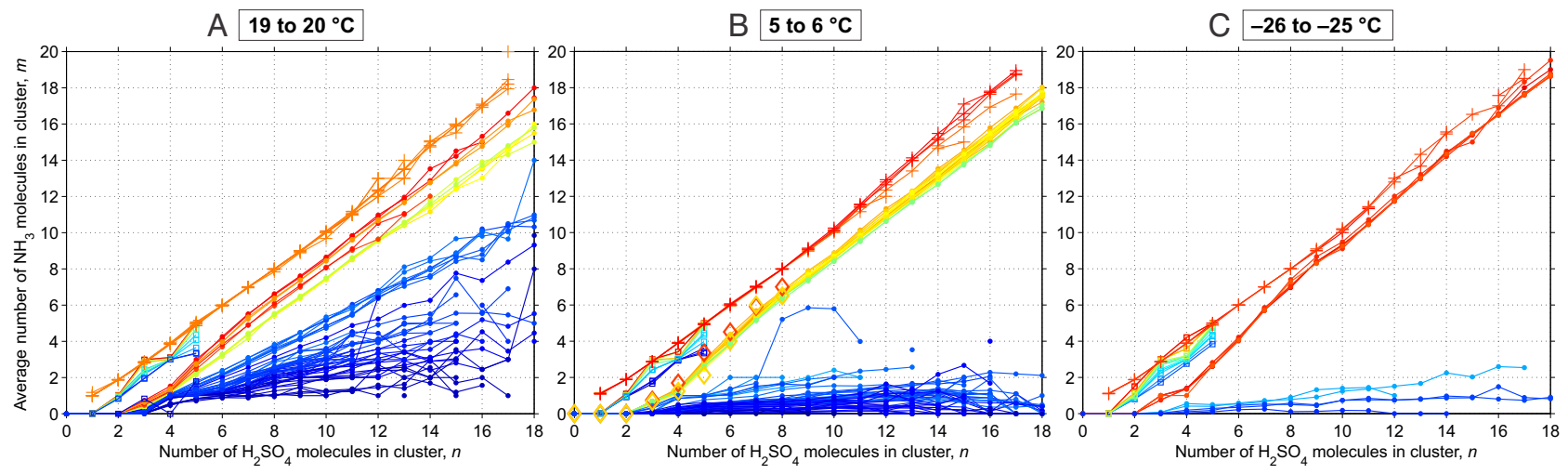

Figure 4. The average number of $\mathrm{NH}_{3}$ molecules $(m)$ in clusters with a certain amount of $\mathrm{H}_{2} \mathrm{SO}_{4}$ molecules $(n)$, for negatively charged clusters $\left(\mathrm{NH}_{3}\right)_{m} \cdot\left(\mathrm{H}_{2} \mathrm{SO}_{4}\right)_{n} \cdot \mathrm{HSO}_{4}^{-}\left(\mathrm{CLOUD}\right.$ experiments, Hyytiälä), positively charged clusters $\left(\mathrm{NH}_{3}\right)_{m} \cdot\left(\mathrm{H}_{2} \mathrm{SO}_{4}\right)_{n} \cdot \mathrm{NH}_{4}^{+}\left(\mathrm{CLOUD} \mathrm{ex}^{-}\right.$ periments) and neutral clusters $\left(\mathrm{NH}_{3}\right)_{m} \cdot\left(\mathrm{H}_{2} \mathrm{SO}_{4}\right)_{n}$ (ACDC model). Experiments are grouped by temperature into panels (a) $\left(19\right.$ to $\left.20^{\circ} \mathrm{C}\right)$, (b) $\left(5\right.$ to $\left.6^{\circ} \mathrm{C}\right)$, (c) $\left(-26\right.$ to $\left.-25^{\circ} \mathrm{C}\right)$; mean relative humidities were $21 \%$ to $84 \%$ (anions, CLOUD), $20 \%$ to $40 \%$ (cations, CLOUD), $41 \%$ and $58 \%$ (anions, Hyytiälä). The resulting curves are near linear from about $n=4$ (anions) or $n=1$ (cations, neutrals) onwards. The principal factor determining the slopes is the ratio of gas-phase concentrations $\left[\mathrm{NH}_{3}\right] /\left[\mathrm{H}_{2} \mathrm{SO}_{4}\right]$ (color scale).

$\mathrm{H}_{2} \mathrm{SO}_{4}$ molecules (n), for each experiment and grouped by temperature.

We define the average number of added $\mathrm{NH}_{3}$ molecules per added $\mathrm{H}_{2} \mathrm{SO}_{4}$ molecule as $\Delta m / \Delta n$. This ratio corresponds to the slope of linear fits in $m$-vs.- $n$ plots as in Fig. 4. For anions, we calculated values of $\Delta m / \Delta n$ for $n \geq 4$, and found that $\Delta m / \Delta n$ is well suited to describe the whole anion spectra during new-particle formation events in the $\mathrm{NH}_{3}-$ $\mathrm{H}_{2} \mathrm{SO}_{4}$ system: two spectra with the same $\Delta m / \Delta n$ were practically identical (unless $\Delta m / \Delta n$ was close to zero, see Sect. 3.5), and, for a given temperature and RH, $\Delta m / \Delta n$ was only dependent on the ratio between the $\mathrm{NH}_{3}$ and $\mathrm{H}_{2} \mathrm{SO}_{4}$ gas-phase concentrations, i.e., on $\left[\mathrm{NH}_{3}\right] /\left[\mathrm{H}_{2} \mathrm{SO}_{4}\right]$ (color scale in Fig. 4, horizontal axis in Fig. 5). In our analysis for this study, values of $\Delta m / \Delta n$ were calculated over the range $4 \leq n \leq 18$ in the case of anion clusters, because $\Delta m / \Delta n$ was approximately constant for $n \geq 4$ and we obtained a signal from clusters up to at least $n=18$ in most of the experiments.

At a given temperature and $\mathrm{RH}$, the resulting $\Delta m / \Delta n$ generally increased with an increasing value of $\left[\mathrm{NH}_{3}\right] /\left[\mathrm{H}_{2} \mathrm{SO}_{4}\right]$, then flattened off when approaching the value of 1 , and eventually reached a saturation value slightly larger than 1 . At $19^{\circ} \mathrm{C}$, the maximum value of $\Delta m / \Delta n$ of 1.1 to 1.2 was reached at the concentration ratio $\left[\mathrm{NH}_{3}\right] /\left[\mathrm{H}_{2} \mathrm{SO}_{4}\right] \approx 100$ (Fig. 5). This concentration ratio was roughly coincident with the threshold for observing cation clusters (at $19^{\circ} \mathrm{C}$ and $40 \% \mathrm{RH}$ ) of the form $\left(\mathrm{NH}_{3}\right)_{m} \cdot\left(\mathrm{H}_{2} \mathrm{SO}_{4}\right)_{n} \cdot \mathrm{NH}_{4}^{+}$with $m \approx n$ and $\Delta m / \Delta n \geq 1$ (Figs. 4, 5). In an analogous way, the NAIS observed a formation of positively charged ions only when positively charged $\mathrm{NH}_{3}-\mathrm{H}_{2} \mathrm{SO}_{4}$ clusters were observable by the APi-TOF. Note that for the cation clusters, $\Delta m / \Delta n$ was nearly constant from the monomer $(n=1)$ onward and it was generally calculated over the range $1 \leq n \leq 17$.

The relationship between $\Delta m / \Delta n$ and $\left[\mathrm{NH}_{3}\right] /\left[\mathrm{H}_{2} \mathrm{SO}_{4}\right]$ was similar under all experimental conditions, but the exact functional form of this relation was temperature dependent (Fig. 6a). For example, the value of $\Delta m / \Delta n=0.2$ was reached at $\left[\mathrm{NH}_{3}\right] /\left[\mathrm{H}_{2} \mathrm{SO}_{4}\right] \approx 0.1$ when the temperature was $19^{\circ} \mathrm{C}$, but at $\left[\mathrm{NH}_{3}\right] /\left[\mathrm{H}_{2} \mathrm{SO}_{4}\right] \approx 0.7$ when it was $5^{\circ} \mathrm{C}$, and at $\left[\mathrm{NH}_{3}\right] /\left[\mathrm{H}_{2} \mathrm{SO}_{4}\right]>1$ when it was $-25^{\circ} \mathrm{C}$. Also, the maximum observed values of $\Delta m / \Delta n$ seemed to be reached at lower values of $\left[\mathrm{NH}_{3}\right] /\left[\mathrm{H}_{2} \mathrm{SO}_{4}\right]$, and these maximum values were slightly higher at lower temperatures (e.g., a maximum $\Delta m / \Delta n$ of 1.1 to 1.2 at $19^{\circ} \mathrm{C}$, versus a maximum $\Delta m / \Delta n$ of 1.3 at $-25^{\circ} \mathrm{C}$ ).

Note that in practically all our experiments with $\left[\mathrm{NH}_{3}\right] /\left[\mathrm{H}_{2} \mathrm{SO}_{4}\right]<1$, only contaminant levels of $\left[\mathrm{NH}_{3}\right]$ were present. These contaminant levels were not directly measured, but calculated under the assumptions described in Sect .2.4. In particular the temperature dependence of these low values of $\left[\mathrm{NH}_{3}\right]$ is subject to those assumptions. Note also that most experiments at CLOUD were run with the RH between $37 \%$ and $41 \%$, so the potential RH effects could not be thoroughly investigated. However, an increase of RH to $>68 \%$ increased the value of $\Delta m / \Delta n$ (Fig. 5). No significant effect on negatively charged clusters was observed due to $\mathrm{RH}$ changes in the range $30 \%<\mathrm{RH}<60 \%$. 


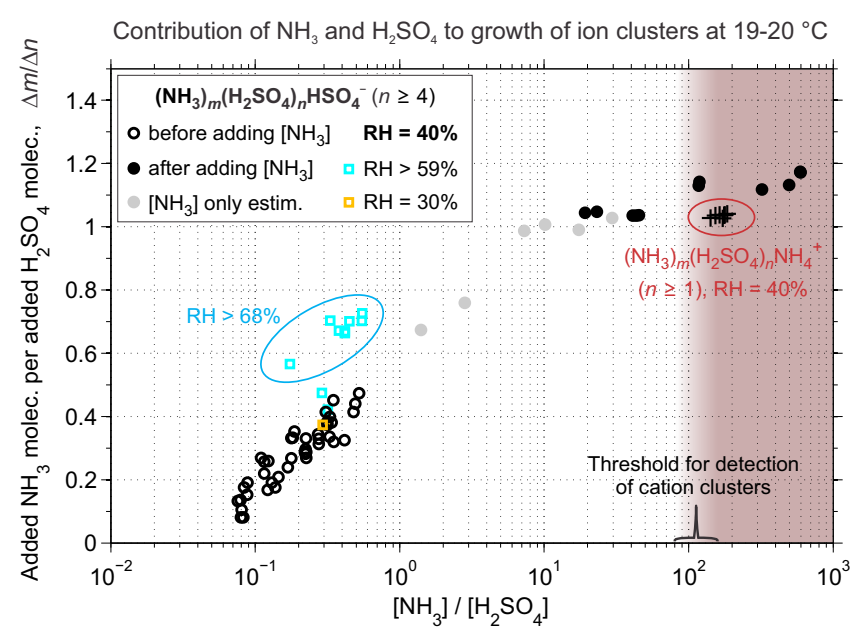

Figure 5. Number of gained $\mathrm{NH}_{3}$ molecules per gained $\mathrm{H}_{2} \mathrm{SO}_{4}$ molecule, $\Delta m / \Delta n$, plotted against the ratio of $\mathrm{NH}_{3}$ and $\mathrm{H}_{2} \mathrm{SO}_{4}$ gas-phase concentrations, $\left[\mathrm{NH}_{3}\right] /\left[\mathrm{H}_{2} \mathrm{SO}_{4}\right]$, for particle formation experiments at 19 to $20^{\circ} \mathrm{C}$, showing a positive correlation. Circles are for anion clusters $\left(\mathrm{NH}_{3}\right)_{m} \cdot\left(\mathrm{H}_{2} \mathrm{SO}_{4}\right)_{n} \cdot \mathrm{HSO}_{4}^{-}$and experiments at a relative humidity (RH) of $37 \%$ to $40 \%$. Colored squares denote experiments at lower $\mathrm{RH}(30 \%)$ or higher $\mathrm{RH}(>59 \%)$. Red pluses show $\Delta m / \Delta n$ for cation clusters $\left(\mathrm{NH}_{3}\right)_{m} \cdot\left(\mathrm{H}_{2} \mathrm{SO}_{4}\right)_{n} \cdot \mathrm{NH}_{4}^{+}$, which are only observed at sufficiently high $\left[\mathrm{NH}_{3}\right] /\left[\mathrm{H}_{2} \mathrm{SO}_{4}\right]$, as indicated by the red-shaded area, at an RH of $39 \%$ to $40 \%$. Values for $\Delta m / \Delta n$ were determined for anion clusters in the range $4 \leq n \leq 18^{*}$, and for cation clusters in the range $1 \leq n \leq 16^{*}$. The lower limits of these ranges correspond to the sizes, from which onward $\Delta m$ / $\Delta n$ were constant. The upper limits were chosen, because up to these sizes a good signal was obtained for most experiments. * Actual upper limits varied depending on obtained signals. The median maximum $n$ was 16 for both anion and cation clusters.

\subsection{Negatively charged $\left(\mathrm{NH}_{3}-\right) \mathrm{H}_{2} \mathrm{SO}_{4}$ clusters at very low $\left[\mathrm{NH}_{3}\right] /\left[\mathrm{H}_{2} \mathrm{SO}_{4}\right]$}

The role of $\mathrm{NH}_{3}$ in the formation of clusters became negligible at very low values of $\left[\mathrm{NH}_{3}\right] /\left[\mathrm{H}_{2} \mathrm{SO}_{4}\right]$, i.e., when $\Delta m / \Delta n$ dropped below 0.1 and the formation of pure binary clusters dominated (Fig. 6). Binary cluster formation is observed by the APi-TOF as pure sulfuric acid anion clusters, $\left(\mathrm{H}_{2} \mathrm{SO}_{4}\right)_{n} \cdot \mathrm{HSO}_{4}^{-}$, because $\mathrm{H}_{2} \mathrm{O}$ molecules are lost in the sampling process (Sect. 2.3). The fraction of pure, $\mathrm{NH}_{3}$ free sulfuric acid clusters was calculated over the same cluster range as was used for calculating $\Delta m / \Delta n(4 \leq n \leq 18)$, and like $\Delta m / \Delta n$, it was a function of $\left[\mathrm{NH}_{3}\right] /\left[\mathrm{H}_{2} \mathrm{SO}_{4}\right]$. The fraction of $\mathrm{NH}_{3}$-free sulfuric acid clusters increased with a decreasing value of $\left[\mathrm{NH}_{3}\right] /\left[\mathrm{H}_{2} \mathrm{SO}_{4}\right]$, and such clusters were observed only below some temperature-dependent threshold value of $\left[\mathrm{NH}_{3}\right] /\left[\mathrm{H}_{2} \mathrm{SO}_{4}\right]$ (Fig. 6b). Taken together, the presence of pure, $\mathrm{NH}_{3}$-free sulfuric acid clusters was favored by lower $\left[\mathrm{NH}_{3}\right] /\left[\mathrm{H}_{2} \mathrm{SO}_{4}\right]$ ratios and lower temperatures.

Note that the $\mathrm{NH}_{3}$ contamination in the CLOUD chamber sets a lower limit to the minimum achievable level of $\left[\mathrm{NH}_{3}\right]$. Therefore, pure binary sulfuric-acid-water cluster formation can only be obtained at sufficiently high $\left[\mathrm{H}_{2} \mathrm{SO}_{4}\right]$ level or at low temperatures. A low temperature both decreases the contaminant level of $\left[\mathrm{NH}_{3}\right]$ (Sect. 2.4) and increases the threshold $\left[\mathrm{NH}_{3}\right] /\left[\mathrm{H}_{2} \mathrm{SO}_{4}\right]$ below which binary cluster formation occurs (Fig. 6b).

\section{Discussion}

\subsection{The composition of negative ions during new-particle formation experiments $\left(\mathrm{no} \mathrm{NH}_{3}\right.$ added)}

Without adding any $\mathrm{NH}_{3}$ into the CLOUD chamber, most anions during a new-particle formation experiment in the CLOUD chamber were small sulfuric acid anion clusters. Heavier anion clusters, containing $>3$ sulfur atoms, were not only "pure" sulfuric acid clusters but also clusters associated with base molecules, namely $\mathrm{NH}_{3}$ or various organic bases, mainly amines (Figs. 2c and 3). These findings agree qualitatively with observations made in the ambient atmosphere (Ehn et al., 2010), with independent measurements of such clusters in the laboratory (Bzdek et al., 2011), as well as with the results of simulations that consider classical collisions and evaporation rates based on quantum chemical methods (Olenius et al., 2013b). Both the earlier experimental and theoretical studies, as well as our results here, show that $\mathrm{NH}_{3}$ molecules can only cluster with anionic $(=$ deprotonated) sulfuric acid clusters, i.e., form $\left(\mathrm{NH}_{3}\right)_{m} \cdot\left(\mathrm{H}_{2} \mathrm{SO}_{4}\right)_{n} \cdot \mathrm{HSO}_{4}^{-}$, if $n>2$. This lower size limit for the inclusion of $\mathrm{NH}_{3}$ molecules is explained by $\mathrm{HSO}_{4}^{-}$itself acting as an electron donor (= Lewis base), in competition with regular bases such as $\mathrm{NH}_{3}$. Only when $n>2$ is the cluster acidic enough to accept $\mathrm{NH}_{3}$ molecules. If $\mathrm{NH}_{3}$ or amines are available, their inclusion into larger clusters $(n>2)$ substantially enhances cluster stability, leading to a higher abundance as well as detectability in our measurements, compared to the corresponding pure sulfuric acid cluster (Ortega et al., 2014).

The observation of both ammonia and amines in these clusters here is remarkable because neither $\mathrm{NH}_{3}$ nor amines were deliberately fed into the CLOUD chamber for these experiments. All $\mathrm{NH}_{3}$ and amines were unintended impurities $\left(\left[\mathrm{NH}_{3}\right]<5 \mathrm{pptv},\left[\mathrm{C}_{2} \mathrm{H}_{7} \mathrm{~N}\right]<1 \mathrm{pptv}\right)$, yet they were found to play a crucial role in the chemistry of growing ion clusters.

\subsection{The role of charge carriers different from $\mathrm{HSO}_{4}^{-}$}

In order of importance, the charge carriers in the observed base-sulfuric-acid clusters were $\mathrm{HSO}_{4}^{-}, \mathrm{HSO}_{5}^{-}, \mathrm{SO}_{5}^{-}$, and $\mathrm{H}_{2} \mathrm{O}_{11} \mathrm{NS}_{2}^{-}$. The $\mathrm{HSO}_{4}^{-}$ion strongly correlated with $\left[\mathrm{H}_{2} \mathrm{SO}_{4}\right]$ and was certainly formed by the de-protonation of $\mathrm{H}_{2} \mathrm{SO}_{4}$. A formation mechanism for $\mathrm{SO}_{5}^{-}$has been investigated by Möhler et al. (1992). The initial step of this mechanism is the formation of $\mathrm{SO}_{3}^{-}$from $\mathrm{SO}_{2}$ by the transfer of $\mathrm{O}^{-}$from $\mathrm{O}_{3}^{-}$. Subsequently, $\mathrm{SO}_{5}^{-}$forms from $\mathrm{SO}_{3}^{-}$and $\mathrm{O}_{2}$ 

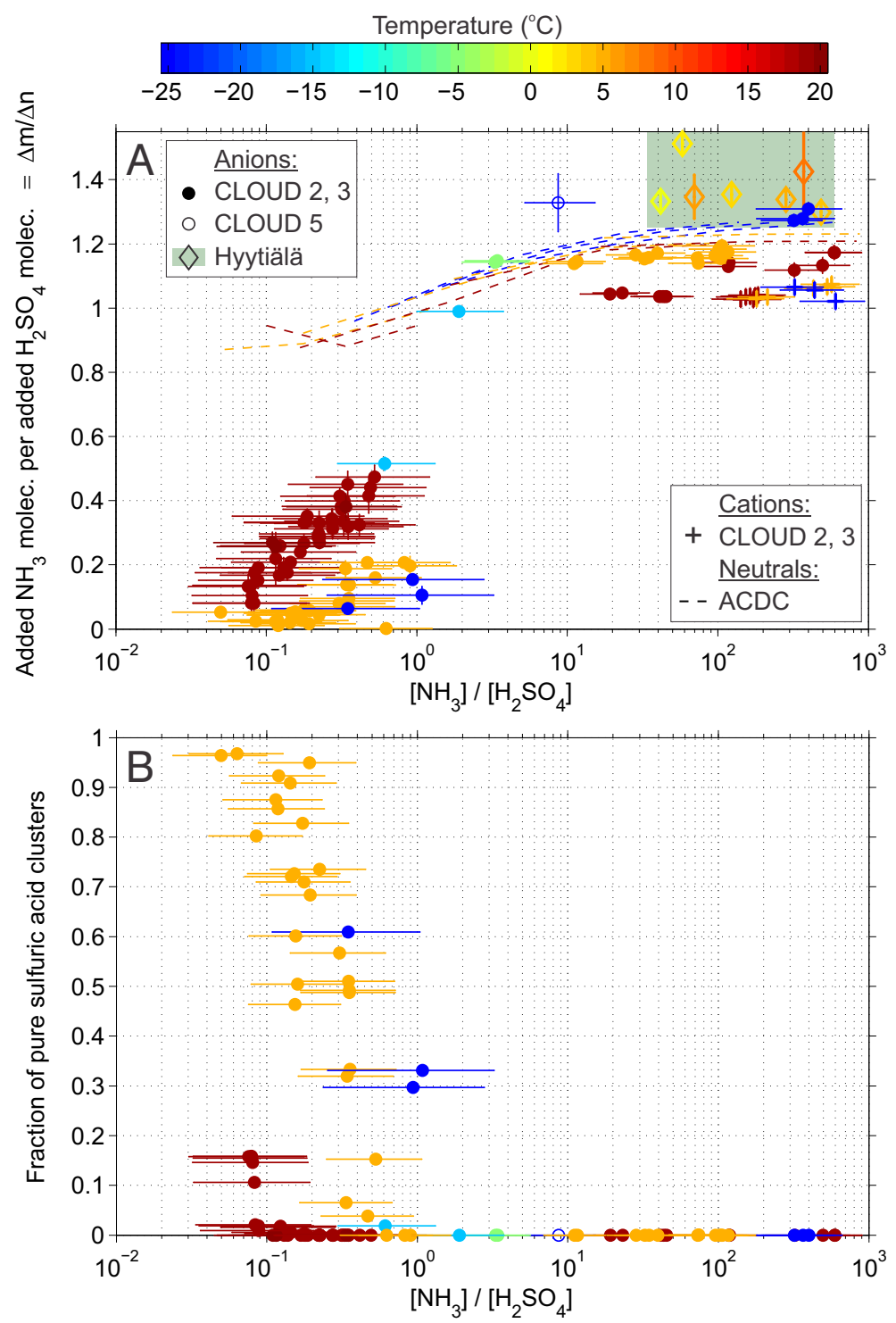

Figure 6. The composition of anion clusters, $\left(\mathrm{NH}_{3}\right)_{m} \cdot\left(\mathrm{H}_{2} \mathrm{SO}_{4}\right)_{n} \cdot \mathrm{HSO}_{4}^{-}$, during new-particle formation experiments in the CLOUD chamber, shown as circles. RH was in the range $37-41 \%$; temperature is given by the color scale. (a) Number of gained $\mathrm{NH}_{3}$ molecules per gained $\mathrm{H}_{2} \mathrm{SO}_{4}$ molecule, $\Delta m / \Delta n$, plotted against the ratio of $\mathrm{NH}_{3}$ and $\mathrm{H}_{2} \mathrm{SO}_{4}$ gas-phase concentrations, $\left[\mathrm{NH}_{3}\right] /\left[\mathrm{H}_{2} \mathrm{SO}_{4}\right] . \Delta m / \Delta n$ for anion clusters was calculated for the range $4 \leq n \leq 18^{*}$ for the results from the CLOUD 2 and 3 campaigns, and for the range $4 \leq n \leq 9$ for the single result from CLOUD 5. Also shown are $\Delta m / \Delta n$ for cation clusters $\left(\mathrm{NH}_{3}\right)_{m} \cdot\left(\mathrm{H}_{2} \mathrm{SO}_{4}\right)_{n} \cdot \mathrm{NH}_{4}^{+}$(for the range $1 \leq n \leq 16^{*}$ ), which are observed only at sufficiently high $\left[\mathrm{NH}_{3}\right] /\left[\mathrm{H}_{2} \mathrm{SO}_{4}\right]$. The green box and diamond markers show the corresponding results from ambient observations in the boreal forest. These are for $\left(\mathrm{NH}_{3}\right)_{m} \cdot\left(\mathrm{H}_{2} \mathrm{SO}_{4}\right)_{n} \cdot \mathrm{HSO}_{4}^{-}, 4 \leq n \leq 8^{*}$, observed during new-particle formation in Hyytiälä in spring 2011. RH varied from $36 \%$ to $61 \%$, temperature from -0.5 to $+8.5^{\circ} \mathrm{C}$. Dashed lines are ACDC model calculations of $\Delta m / \Delta n$ for neutral clusters $\left(\mathrm{NH}_{3}\right)_{m} \cdot\left(\mathrm{H}_{2} \mathrm{SO}_{4}\right)_{n}$ in the range $1 \leq n \leq 5$. (b) Fraction of pure, $\mathrm{NH}_{3}$-free sulfuric acid anion clusters, $\left(\mathrm{H}_{2} \mathrm{SO}_{4}\right)_{n} \cdot \mathrm{HSO}_{4}^{-}$, calculated for the same ranges of $n$ as in (a), and again plotted against $\left[\mathrm{NH}_{3}\right] /\left[\mathrm{H}_{2} \mathrm{SO}_{4}\right]$. The legends in (a) apply to (b) as well. ${ }^{*}$ Actual upper limits varied depending on obtained signals. For anion clusters in the CLOUD 2 and 3 campaigns, median $\left(n_{\max }\right)=16.5$; for cation clusters, median $\left(n_{\max }\right)=16$; for anion clusters in Hyytiälä, median $\left(n_{\max }\right)=7$.

with a mediating $\mathrm{N}_{2}$ or $\mathrm{H}_{2} \mathrm{O}$. We observed that $\mathrm{O}_{3}$ in the CLOUD chamber was required for the formation of both $\mathrm{SO}_{5}^{-}$and $\mathrm{HSO}_{5}^{-}$, supporting these or similar ion-molecule reactions as a source. Possible origins of the $\mathrm{HSO}_{5}^{-}$ions were ion-molecule reactions similar to those probably leading to the formation of $\mathrm{SO}_{5}^{-}$, a proton-transfer reaction with peroxymonosulfuric acid $\mathrm{H}_{2} \mathrm{SO}_{5}$, or the electronic charging of $\mathrm{HSO}_{5}$, while $\mathrm{HSO}_{5}$ itself had possibly been formed as described in Kurtén et al. (2009). $\mathrm{H}_{2} \mathrm{O}_{11} \mathrm{NS}_{2}^{-}$was probably $\mathrm{H}_{2} \mathrm{~S}_{2} \mathrm{O}_{8} \cdot \mathrm{NO}_{3}^{-} \cdot \mathrm{H}_{2} \mathrm{~S}_{2} \mathrm{O}_{8}$ might have been formed from hy- 
drated $\mathrm{SO}_{5}$ or from $\mathrm{HSO}_{5}$ (Kurtén et al., 2009). Nitric acid $\left(\mathrm{HNO}_{3}\right)$ and its conjugate base $\mathrm{NO}_{3}^{-}$were present as contaminants in the chamber.

By far the most abundant ions during the new-particle formation experiments at CLOUD that are discussed here were the clusters of type $\left(\mathrm{NH}_{3}\right)_{m} \cdot\left(\mathrm{H}_{2} \mathrm{SO}_{4}\right)_{n} \cdot \mathrm{HSO}_{4}^{-}$and $\left(\mathrm{NH}_{3}\right)_{m} \cdot\left(\mathrm{H}_{2} \mathrm{SO}_{4}\right)_{n} \cdot \mathrm{HSO}_{5}^{-}$. The latter type gains relevance in conditions of high $\left[\mathrm{NH}_{3}\right]$. Ammonia was present at $n \geq 2$ in the $\mathrm{HSO}_{5}^{-}$-based clusters but at $n \geq 3$ in the $\mathrm{HSO}_{4}^{-}$-based clusters. This suggests that sulfuric acid ion clusters will cluster more readily (i.e., build more stable clusters) with $\mathrm{NH}_{3}$ when the charge-carrying component is $\mathrm{HSO}_{5}^{-}$instead of $\mathrm{HSO}_{4}^{-}$. Most likely, this was the primary reason for the observed increase of the fraction of $\mathrm{HSO}_{5}^{-}$-based clusters at higher values of $\left[\mathrm{NH}_{3}\right]$. A secondary reason was the lower $\left[\mathrm{H}_{2} \mathrm{SO}_{4}\right]$ during such experiments, which was usually coincidental. The only other difference to the $\mathrm{HSO}_{4}^{-}$-based clusters was an initially higher ratio $m / n$, as a direct consequence of the acceptance of $\mathrm{NH}_{3}$ molecules already at $n=2$. However, the composition of the clusters was otherwise the same, and the prevalent mechanism of cluster growth was not affected, namely the addition of a certain number of $\mathrm{NH}_{3}$ molecules per $\mathrm{H}_{2} \mathrm{SO}_{4}$ molecule. Therefore, we conclude that the presence and actions of charge carriers other than $\mathrm{HSO}_{4}^{-}$do not alter the conclusions of this study. Interestingly, when $n \geq 9$, differences in the ratio $m / n$ disappeared or became approximately constant, suggesting that at about that size the ion cluster had become large enough to render any chemical effect of its charge-carrying component unimportant.

In conclusion, we suggest that $\mathrm{HSO}_{5}^{-}$is a somewhat weaker Lewis base than $\mathrm{HSO}_{4}^{-}$. Therefore, clusters containing $\mathrm{HSO}_{5}^{-}$more readily take up bases and less readily acids, as compared with clusters containing $\mathrm{HSO}_{4}^{-}$, in line with all of our observations. Furthermore, the highest prevalence of $\mathrm{HSO}_{5}^{-}$in all experiments at the CLOUD chamber to date has been in the dimethylamine- $\mathrm{H}_{2} \mathrm{SO}_{4}$ anion clusters that were produced during later experiments (in 2011 and 2012) following the addition of dimethylamine, a stronger base than $\mathrm{NH}_{3}$ (Almeida et al., 2013).

\subsection{The role of contaminant levels of amines in the formation and growth of anion clusters}

Throughout our experiments, contaminant levels of amines were below the limit of direct detection. We estimate the gas-phase contaminant concentrations of $\mathrm{C}_{2} \mathrm{H}_{7} \mathrm{~N}$ between 0.1 and 1 pptv during the CLOUD 2 campaign, and about 0.1 pptv during the CLOUD 3 campaign, but they may have been even lower. The most abundant contaminant amine observed in anionic clusters was $\mathrm{C}_{2} \mathrm{H}_{7} \mathrm{~N}$, and the most abundant cluster containing $\mathrm{C}_{2} \mathrm{H}_{7} \mathrm{~N}$ was $\mathrm{C}_{2} \mathrm{H}_{7} \mathrm{~N} \cdot\left(\mathrm{H}_{2} \mathrm{SO}_{4}\right)_{3} \cdot \mathrm{HSO}_{4}^{-}$ (Fig. 3). Note that $\mathrm{C}_{2} \mathrm{H}_{7} \mathrm{~N} \cdot\left(\mathrm{H}_{2} \mathrm{SO}_{4}\right)_{2} \cdot \mathrm{HSO}_{4}^{-}$was observed, whereas $\mathrm{NH}_{3} \cdot\left(\mathrm{H}_{2} \mathrm{SO}_{4}\right)_{2} \cdot \mathrm{HSO}_{4}^{-}$was not. Nevertheless, the growth of the clusters at contaminant levels of amines pro- ceeded almost exclusively by the addition of $\mathrm{NH}_{3}$ and $\mathrm{H}_{2} \mathrm{SO}_{4}$ molecules. The resultant dominant role of $\mathrm{NH}_{3}$ in the growth of the clusters, as opposed to organic bases (amines or amides), is most likely due to the differences in respective contaminant-level concentrations $\left(\left[\mathrm{NH}_{3}\right]\right.$ about 2 to 4 pptv, $\left.\left[\mathrm{C}_{2} \mathrm{H}_{7} \mathrm{~N}\right]<1 \mathrm{pptv}\right)$. Indeed, previous experimental studies on both positively and negatively charged dimethylamine- $\mathrm{NH}_{3}-\mathrm{H}_{2} \mathrm{SO}_{4}$ clusters showed that dimethylamine molecules would quickly displace $\mathrm{NH}_{3}$ molecules in these clusters already at low-pptv-level amine concentrations, whereas the opposite (displacement of dimethylamine by $\mathrm{NH}_{3}$ molecules) does not occur even at much higher gasphase $\mathrm{NH}_{3}$ concentrations (Bzdek et al., 2010; Bzdek et al., 2011).

The effect of higher than contaminant gas-phase concentrations of amines, in particular of dimethylamine, on the composition of growing clusters and on particle formation rates was thoroughly investigated in subsequent CLOUD campaigns (Almeida et al., 2013; Bianchi et al., 2014). A large influence on cluster formation and particle formation rates was found at dimethylamine concentrations as low as 3 pptv. Specifically, growing ion clusters consisted of practically only dimethylamine and $\mathrm{H}_{2} \mathrm{SO}_{4}$, and particle formation rates were significantly enhanced. The enhancement of particle formation rates in those experiments was due to dimethylamine being a stronger base than $\mathrm{NH}_{3}$ and consequently forming more stable bonds with $\mathrm{H}_{2} \mathrm{SO}_{4}$ molecules, as has been shown both theoretically (e.g., Bzdek et al., 2010) and experimentally (e.g., Kurtén et al., 2008). The same reason can account for the observation (here, as in Almeida et al., 2013) that dimethylamine binds first to the sulfuric acid trimer anion, whereas $\mathrm{NH}_{3}$ requires one more $\mathrm{H}_{2} \mathrm{SO}_{4}$ in the cluster and binds first to the sulfuric acid tetramer anion. Specifically, dimethylamine competes more successfully than $\mathrm{NH}_{3}$ against $\mathrm{HSO}_{4}^{-}$, which acts as a strong Lewis base in these clusters.

However, in the experiments presented here, no effect on the rate of new-particle formation was observed due to the contaminant levels of amines ( $<1 \mathrm{pptv})$. Also, the composition of the growing ion clusters was dominated by $\mathrm{NH}_{3}$ and appeared to be unaffected by the occasional inclusion of an amine.

Interestingly, a similar dominance of $\mathrm{NH}_{3}$ over amines is also apparent in the composition of base-sulfuric-acid ion clusters that were observed during new-particle formation in the ambient atmosphere, specifically in the boreal forest environment in Hyytiälä, Finland (Kulmala et al., 2013; Schobesberger et al., 2013a). However, it was also shown that other oxidized organic compounds participate in those atmospheric new-particle formation events as well from an early stage on (Ehn et al., 2014), suggesting more complex mechanisms of formation and growth of clusters, which have not yet been determined in detail. 


\subsection{The composition of $\mathrm{NH}_{3}-\mathrm{H}_{2} \mathrm{SO}_{4}$ clusters in the CLOUD laboratory experiments}

The APi-TOF measurements of $\mathrm{NH}_{3}-\mathrm{H}_{2} \mathrm{SO}_{4}$ clusters during particle formation experiments at the CLOUD chamber revealed that these clusters grow by the accretion of certain numbers of $\mathrm{NH}_{3}$ and $\mathrm{H}_{2} \mathrm{SO}_{4}$ molecules. The measurements covered the range up to clusters containing about 27 sulfur atoms. This maximum size corresponds to $2.1 \mathrm{~nm}$ in mobility equivalent diameter, when converted according to Ehn et al. (2011) using the bulk density of ammonium bisulfate ( $1780 \mathrm{~kg} \mathrm{~m}^{-3}$; and neglecting a likely involvement of $\mathrm{H}_{2} \mathrm{O}$ ).

The anion clusters were mainly of the form $\left(\mathrm{NH}_{3}\right)_{m} \cdot\left(\mathrm{H}_{2} \mathrm{SO}_{4}\right)_{n} \cdot \mathrm{HSO}_{4}^{-}$. The $\mathrm{HSO}_{4}^{-}$ion acts as a strong Lewis base, so stable bonds with $\mathrm{NH}_{3}$ molecules are only possible for $n \geq 3$. For larger clusters $(n \geq 4)$, the cluster growth was well characterized by the ratio of added $\mathrm{NH}_{3}$ molecules per added $\mathrm{H}_{2} \mathrm{SO}_{4}$ molecule, $\Delta m / \Delta n$, which we found to be dependent on the ratio $\left[\mathrm{NH}_{3}\right] /\left[\mathrm{H}_{2} \mathrm{SO}_{4}\right]$ and temperature (Figs. 4, 6a). At sufficiently high values of $\left[\mathrm{NH}_{3}\right] /\left[\mathrm{H}_{2} \mathrm{SO}_{4}\right], \Delta m / \Delta n$ saturated at just above unity. Note that a ratio of $\Delta m / \Delta n=1$ corresponds to the stabilization of each $\mathrm{H}_{2} \mathrm{SO}_{4}$ molecule by an $\mathrm{NH}_{3}$ molecule, as in ammonium bisulfate (whereas $\Delta m / \Delta n=2$ would correspond to the full neutralization of each $\mathrm{H}_{2} \mathrm{SO}_{4}$ molecule by two $\mathrm{NH}_{3}$ molecules, as in ammonium sulfate). All these observations make it very likely that the binding of molecules via strong hydrogen bonds between acidic and basic molecules and acid-base reactions were the dominant mechanism in both the initial formation of these clusters and their subsequent growth up to $>2 \mathrm{~nm}$. The basic molecules were the $\mathrm{HSO}_{4}^{-}$ion and $\mathrm{NH}_{3}$ molecules, while the acidic molecules were $\mathrm{H}_{2} \mathrm{SO}_{4}$ molecules. In terms of cluster composition, therefore, the chemical property of $\mathrm{HSO}_{4}^{-}$appears to outweigh electrostatic effects due to the electric charge. Consequently, the enhancements of particle formation rates attributed to $\mathrm{NH}_{3}$ or to a negative charge (Kirkby et al., 2011) may both be the consequence of essentially the same process of acid-base stabilization (Kupiainen et al., 2012).

These findings are in agreement with previous studies that investigated the structure of the bonds in electrically charged or neutral $\mathrm{NH}_{3}-\mathrm{H}_{2} \mathrm{SO}_{4}$ clusters: both theoretical (e.g., Ortega et al., 2012; DePalma et al., 2012; Ortega et al., 2014) and experimental studies (e.g., Rozenberg et al., 2011; Froyd and Lovejoy, 2012; Johnson and Johnson, 2013) have shown that $\mathrm{NH}_{3}$ molecules are bound to $\mathrm{H}_{2} \mathrm{SO}_{4}$ molecules via the transfer of a proton from the acid to the base (acid-base reaction) in all but the smallest of these clusters. Note that for simplicity, the chemical formulas used in this paper disregard these reactions.

Note also that all of the observed clusters were probably hydrated before their $\mathrm{H}_{2} \mathrm{O}$ molecules were lost in the sampling process, due to the abundance of $\mathrm{H}_{2} \mathrm{O}$ at the conditions in the CLOUD chamber (e.g., Henschel et al., 2014). The stabilizing effect of $\mathrm{H}_{2} \mathrm{O}$ on $\mathrm{H}_{2} \mathrm{SO}_{4}$ is much smaller than that of

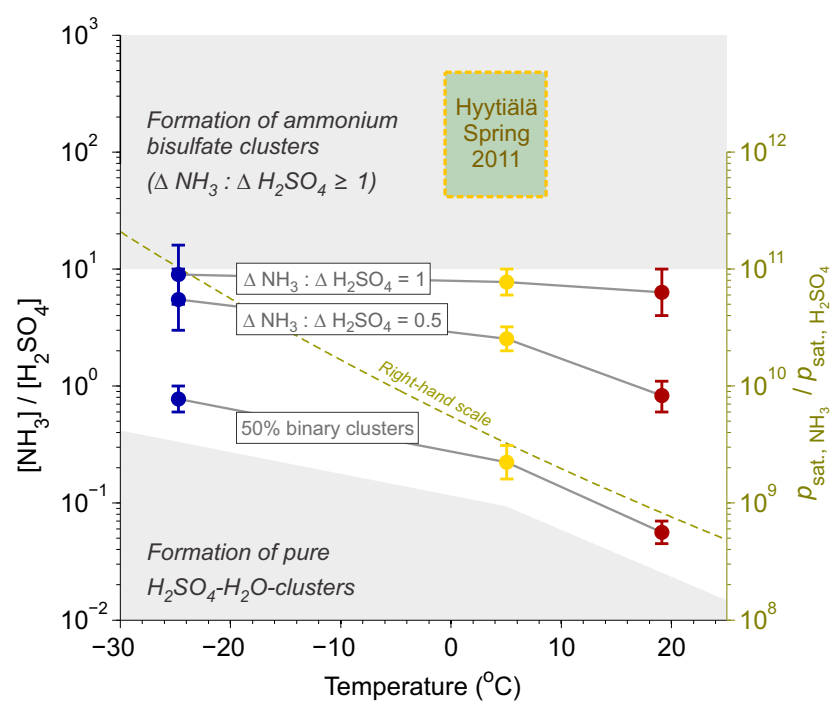

Figure 7. Summary of the observed composition of $\left(\mathrm{NH}_{3}\right)_{m} \cdot\left(\mathrm{H}_{2} \mathrm{SO}_{4}\right)_{n} \cdot \mathrm{HSO}_{4}^{-}$anion clusters for the covered experimental conditions: varying vapor concentration ratios $\left[\mathrm{NH}_{3}\right] /\left[\mathrm{H}_{2} \mathrm{SO}_{4}\right]$ (left vertical axis) and temperatures (horizontal axis and same color scale as for Fig. 6). Three specific features of cluster composition are presented at three investigated temperatures each, by a total of nine circles. These three features are (1) a fraction of $50 \%$ of pure, $\mathrm{NH}_{3}$-free sulfuric acid clusters, (2) a ratio of added $\mathrm{NH}_{3}$ molecules per added $\mathrm{H}_{2} \mathrm{SO}_{4}$ molecule, $\Delta m / \Delta n$, $=0.5$, and (3) $\Delta m / \Delta n=1$. Values and uncertainties are based on the data shown in Fig. 6. Consequently, the grey shaded area at the bottom covers conditions allowing the formation of pure binary $\left(\mathrm{NH}_{3}\right.$-free) $\mathrm{H}_{2} \mathrm{O}-\mathrm{H}_{2} \mathrm{SO}_{4}$ clusters. The grey shaded area at the top covers conditions that allow for the formation of clusters with about equal numbers of $\mathrm{NH}_{3}$ and $\mathrm{H}_{2} \mathrm{SO}_{4}$ molecules (as in ammonium bisulfate). The position of the green box and the color of its dashed edge line mark the conditions during the measurements in the boreal forest (Hyytiälä). Shown in brown (right vertical axis and line) is the ratio of saturation vapor pressures of $\mathrm{NH}_{3}$ and $\mathrm{H}_{2} \mathrm{SO}_{4}$ $\left(p_{\text {sat., } \mathrm{NH}_{3}} / p_{\text {sat., } \mathrm{H}_{2} \mathrm{SO}_{4}}\right)$.

$\mathrm{NH}_{3}$ (e.g., Kurtén et al., 2007a; DePalma et al., 2014), but at least in the absence of $\mathrm{NH}_{3}$, the contribution of $\mathrm{H}_{2} \mathrm{O}$ is important (e.g., Vehkamäki et al., 2002).

In Fig. 7 we summarize the characteristics of the observed composition of $\left(\mathrm{NH}_{3}\right)_{m} \cdot\left(\mathrm{H}_{2} \mathrm{SO}_{4}\right)_{n} \cdot \mathrm{HSO}_{4}^{-}$anion clusters as a function of vapor concentration ratio $\left[\mathrm{NH}_{3}\right] /\left[\mathrm{H}_{2} \mathrm{SO}_{4}\right]$ and temperatures. Pure binary $\mathrm{H}_{2} \mathrm{SO}_{4}-\mathrm{H}_{2} \mathrm{O}$ cluster formation was favored by low values of $\left[\mathrm{NH}_{3}\right] /\left[\mathrm{H}_{2} \mathrm{SO}_{4}\right]$ and low temperatures. From a macroscopic point of view, this temperature dependence is consistent with the differences in the temperature dependences of the saturation vapor pressures of bulk $\mathrm{H}_{2} \mathrm{SO}_{4}$ and $\mathrm{NH}_{3}$. Namely, the saturation vapor pressure of $\mathrm{H}_{2} \mathrm{SO}_{4}$ decreases more steeply than that of $\mathrm{NH}_{3}$ with decreasing temperature (Vehkamäki et al., 2002; Hodgman, 1962); therefore the ratio of these pressures $\left(p_{\text {sat., }} \mathrm{NH}_{3} / p_{\text {sat., }} \mathrm{H}_{2} \mathrm{SO}_{4}\right)$ increases with decreasing temperature. 
From a molecular-level point of view, the influence of $\mathrm{NH}_{3}$ vs. $\mathrm{H}_{2} \mathrm{SO}_{4}$ vapors on the growing clusters is consistent with a barrier for addition of $\mathrm{NH}_{3}$ to the clusters but barrierless addition of $\mathrm{H}_{2} \mathrm{SO}_{4}$. This has also been deduced from surface-induced cluster dissociation and quantum chemistry (Bzdek et al., 2013). Specifically, the near-saturation of the $\mathrm{NH}_{3}$ content of the clusters at $\left[\mathrm{NH}_{3}\right] /\left[\mathrm{H}_{2} \mathrm{SO}_{4}\right]>10$ suggests that roughly 10 collisions of $\mathrm{NH}_{3}$ with an under-neutralized cluster are necessary to add the base molecule to a growing cluster, or to overwhelm the evaporation rate of $\mathrm{NH}_{3}$ from the cluster. The presence of a barrier for the $\mathrm{NH}_{3}$ uptake would be expected to lead to a slower $\mathrm{NH}_{3}$ uptake at lower temperatures. Such a temperature dependence is consistent with the increased value of $\left[\mathrm{NH}_{3}\right] /\left[\mathrm{H}_{2} \mathrm{SO}_{4}\right]$ required at lower temperatures to add $\mathrm{NH}_{3}$ molecules to under-saturated $\mathrm{NH}_{3}-\mathrm{H}_{2} \mathrm{SO}_{4}$ or $\mathrm{H}_{2} \mathrm{SO}_{4}$ clusters (Figs. 6, 7).

At high values of $\left[\mathrm{NH}_{3}\right] /\left[\mathrm{H}_{2} \mathrm{SO}_{4}\right]$, the ratio $\Delta m / \Delta n$ usually exceeded 1 , approaching saturation (Figs. 6a, 7). This relationship appeared independent of the temperature within uncertainties and the investigated temperature range ( -25 to $20^{\circ} \mathrm{C}$ ). However, our data set may not be sufficiently complete to resolve possible dependencies on temperature. In this regime of high values of $\left[\mathrm{NH}_{3}\right] /\left[\mathrm{H}_{2} \mathrm{SO}_{4}\right]$, cation clusters of the form $\left(\mathrm{NH}_{3}\right)_{m} \cdot\left(\mathrm{H}_{2} \mathrm{SO}_{4}\right)_{n} \cdot \mathrm{NH}_{4}^{+}$were also observable, again with $\Delta m / \Delta n \geq 1$ (Fig. 6a). Note that the anion clusters tended to feature slightly higher saturation values of $\Delta m / \Delta n$ at lower temperatures. This feature could be an indication of the enhanced evaporation of $\mathrm{NH}_{3}$ molecules from the clusters at higher temperatures, before or after the sampling. Indeed, results of computer simulations using the atmospheric cluster dynamics code (ACDC) suggest that there may be a systematic slight underestimation of the $\mathrm{NH}_{3}$ content of the experimentally observed clusters in these conditions of relatively abundant gas-phase $\mathrm{NH}_{3}$ that we cannot exclude (Olenius et al., 2013b; Olenius et al., 2013a). Those as well as earlier studies (e.g., Kurtén et al., 2007b) have demonstrated how at least small $\mathrm{NH}_{3}-\mathrm{H}_{2} \mathrm{SO}_{4}$ clusters are expected to hold onto a higher number of $\mathrm{NH}_{3}$ molecules at lower temperatures.

Since both the anion and cation clusters had $\Delta m / \Delta n$ slightly above unity when $\left[\mathrm{NH}_{3}\right] /\left[\mathrm{H}_{2} \mathrm{SO}_{4}\right] \geq 10$, the clusters became slightly less acidic as they grew. The mass defect diagrams of the corresponding ion mass spectra illustrate the details on the increase of the clusters' base content as they grew (Fig. 8a, b). The anion clusters were seen to grow first by the addition of acids due to the high basicity of $\mathrm{HSO}_{4}^{-}$. From the tetramer onwards (\#S $\geq 4$; see Sect. 4.2 for exceptions), the anions became chemically (not electrically) neutralized, as the clusters grew by the addition of slightly more than one base per acid on average (Fig. 8b). For the cation clusters, $\mathrm{NH}_{3}$ was already present for a monomer (i.e., $\mathrm{NH}_{3} \cdot \mathrm{H}_{2} \mathrm{SO}_{4} \mathrm{NH}_{4}^{+}$), and the clusters became slightly more basic from the first step onwards (Fig. 8a). The maximum observed $\Delta m / \Delta n$ ratios were about 1.4 for anion clusters and 1.1 for cation clusters. Therefore the $\mathrm{NH}_{3}-\mathrm{H}_{2} \mathrm{SO}_{4}$
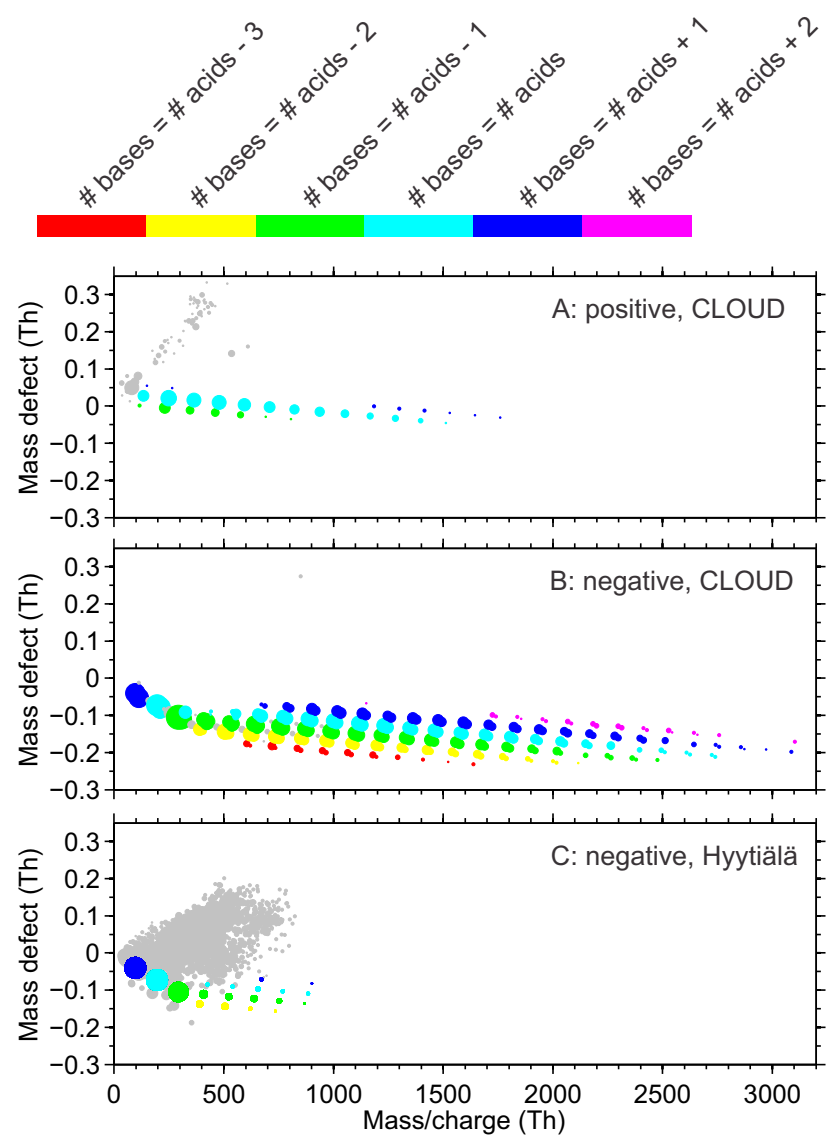

Figure 8. Mass defect diagrams of ion mass spectra during newparticle formation. The $\mathrm{NH}_{3}-\mathrm{H}_{2} \mathrm{SO}_{4}$ ion clusters are colored; other ions are shown in grey. The colors reflect the relative numbers of acids and bases in the cluster, counting $\mathrm{NH}_{3}, \mathrm{HSO}_{4}^{-}, \mathrm{HSO}_{5}^{-}$ and $\mathrm{SO}_{5}^{-}$as bases, and $\mathrm{H}_{2} \mathrm{SO}_{4}$ as acid, and not counting $\mathrm{NH}_{4}^{+}$. (a) Positively charged clusters $\left(\mathrm{NH}_{3}\right)_{m} \cdot\left(\mathrm{H}_{2} \mathrm{SO}_{4}\right)_{n} \cdot \mathrm{NH}_{4}^{+}$during new-particle formation at CLOUD at $\left[\mathrm{NH}_{3}\right] /\left[\mathrm{H}_{2} \mathrm{SO}_{4}\right]=185$, temperature $(T)=19^{\circ} \mathrm{C}$. Other ions (in grey) are mostly organic, Ncontaining contaminants, such as pyridine, charged by protonation. (b) Negatively charged clusters $\left(\mathrm{NH}_{3}\right)_{m} \cdot\left(\mathrm{H}_{2} \mathrm{SO}_{4}\right)_{n} \cdot \mathrm{HSO}_{4}^{-}$ and $\left(\mathrm{NH}_{3}\right)_{m} \cdot\left(\mathrm{H}_{2} \mathrm{SO}_{4}\right)_{n} \cdot \mathrm{HSO}_{5}^{-}$during new-particle formation at CLOUD at $\left[\mathrm{NH}_{3}\right] /\left[\mathrm{H}_{2} \mathrm{SO}_{4}\right]=118, T=19^{\circ} \mathrm{C}$. (c) $\mathrm{Neg}$ atively charged clusters $\left(\mathrm{NH}_{3}\right)_{m} \cdot\left(\mathrm{H}_{2} \mathrm{SO}_{4}\right)_{n} \cdot \mathrm{HSO}_{4}^{-}$during a new-particle formation event in the boreal forest, Hyytiälä, at $\left[\mathrm{NH}_{3}\right] /\left[\mathrm{H}_{2} \mathrm{SO}_{4}\right]=485, T=1$ to $5^{\circ} \mathrm{C}$. Most of the signal of other ions (in grey) has a more positive mass defect and likely arises from ions containing mainly a variety of oxidized organics.

molar ratio $(m / n)$ exceeded unity beyond a certain cluster size, as illustrated in Fig. 9. Note that if the clusters' growth continued to adhere to the observed $\Delta m / \Delta n$ ratios also beyond a mobility size of $2 \mathrm{~nm}, m / n$ would approach these values (grey curves in Fig. 9). And if $\Delta m / \Delta n$ stayed below 1.5 , as observed, also for larger clusters, ammonium bisulfate would remain the favored composition (as opposed to ammonium sulfate). However, it should also be noted here that for 


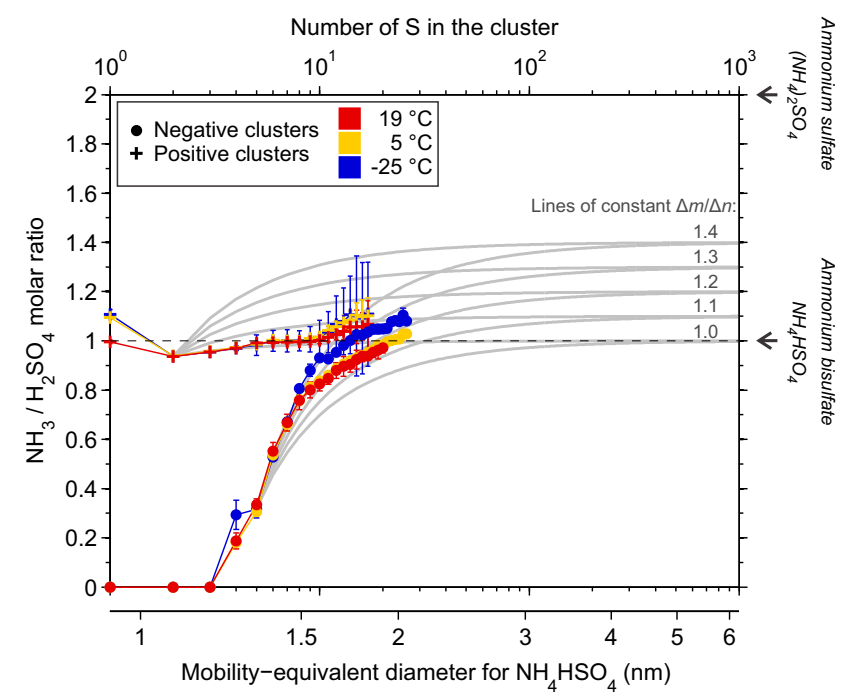

Figure 9. The average measured $\mathrm{NH}_{3} / \mathrm{H}_{2} \mathrm{SO}_{4}$ molar ratio in the negatively and the positively charged $\mathrm{NH}_{3}-\mathrm{H}_{2} \mathrm{SO}_{4}$ clusters, plotted against cluster size, which is approximated by the number of $\mathrm{S}$ atoms in the clusters. The secondary abscissa shows the corresponding mobility-equivalent diameter for these clusters, assuming an $\mathrm{NH}_{3} / \mathrm{H}_{2} \mathrm{SO}_{4}$ molar ratio $=1$ and a density of $1780 \mathrm{~kg} \mathrm{~m}^{-3}$ (i.e., ammonium bisulfate). $\mathrm{An} \mathrm{NH}_{3} / \mathrm{H}_{2} \mathrm{SO}_{4}$ molar ratio $=2$ would correspond to ammonium sulfate. The presented data are uncertainty-weighted averages over the observations from the CLOUD chamber experiments in the respective conditions that yielded the maximum $\mathrm{NH}_{3}$ content in the clusters at three different temperatures. Shown as grey curves are calculated results assuming growth following a constant $\Delta m / \Delta n$, starting from the observed average $m$ at $n=4$ (anions) or $n=2$ (cations).

the positively charged clusters both Fig. 4 and, more clearly, Fig. 9 reveal an apparent discontinuity at $m=n=10$, with an increase of the slopes, specifically an increase of $\Delta m / \Delta n$ from 1.0 to about 1.3 for the larger positively charged clusters.

Interestingly, we observed a wider range of the number of $\mathrm{NH}_{3}$ molecules $m$ for any $n$ in anion clusters than in cation clusters. We hypothesize that this observation follows from the requirement that $\mathrm{NH}_{3}-\mathrm{H}_{2} \mathrm{SO}_{4}$ clusters be basic enough to accept an additional proton (therefore becoming or staying positively charged), whereas they need to be acidic enough to donate a proton (therefore becoming or staying negatively charged). Sulfuric acid can form clusters with only itself (plus $\mathrm{H}_{2} \mathrm{O}$ ) much more readily than can $\mathrm{NH}_{3}$. Therefore, highly acidic $\left(\mathrm{NH}_{3}-\right) \mathrm{H}_{2} \mathrm{SO}_{4}$ clusters can be formed, and they were indeed observed as anion clusters when $\left[\mathrm{NH}_{3}\right] /\left[\mathrm{H}_{2} \mathrm{SO}_{4}\right]$ was sufficiently low (e.g., Fig. 2c). For these clusters $\Delta m / \Delta n$ was $<1$; that is, they continuously became more acidic as they grew. The possibility of such relatively acidic anion clusters leads to the wider range of observed $m$ even at relatively high $\left[\mathrm{NH}_{3}\right]$. On the other hand, the maximum basicity of $\mathrm{NH}_{3}-\mathrm{H}_{2} \mathrm{SO}_{4}$ clusters (or their $\mathrm{NH}_{3} / \mathrm{H}_{2} \mathrm{SO}_{4}$ molar ratio, $m / n$ ) is apparently limited, even at the highest investigated $\left[\mathrm{NH}_{3}\right]$ (Fig. 6a). Only such relatively basic clusters can be observed as cation clusters.

Note that almost all of our experiments were performed with $\mathrm{RH}$ between $37 \%$ and $41 \%$. Indeed, the data presented in Fig. 5 show that the observed $\mathrm{NH}_{3}-\mathrm{H}_{2} \mathrm{SO}_{4}$ clusters contained more $\mathrm{NH}_{3}$ at $\mathrm{RH}>68 \%$. It remains a task for future studies to thoroughly investigate how the composition of these clusters changes with changing $\mathrm{RH}$. It is also worth noting that the APi-TOF was set to measure positively charged clusters in only few experiments; only for experiments at $19^{\circ} \mathrm{C}$ did these experiments include conditions with $\left[\mathrm{NH}_{3}\right] /\left[\mathrm{H}_{2} \mathrm{SO}_{4}\right]<100$.

\subsection{Comparison to the composition of electrically neutral clusters from the ACDC model}

In this work we hypothesize that the growth mechanism of ionic $\mathrm{NH}_{3}-\mathrm{H}_{2} \mathrm{SO}_{4}$ clusters is governed chiefly by hydrogen bonds and ionic bonds formed by acids and bases and the availability of the gas-phase precursors $\mathrm{NH}_{3}$ and $\mathrm{H}_{2} \mathrm{SO}_{4}$. The electric charge somewhat increases the stability (Olenius et al., 2013a), but most importantly it provides an additional base in the form of $\mathrm{HSO}_{4}^{-}$, whereas the $\mathrm{NH}_{4}^{+}$ion seems to exhibit neither strongly basic nor acidic behavior. At relatively high $\left[\mathrm{NH}_{3}\right]$, both positively and negatively charged $\mathrm{NH}_{3}-$ $\mathrm{H}_{2} \mathrm{SO}_{4}$ clusters grow by adding $\mathrm{NH}_{3}$ and $\mathrm{H}_{2} \mathrm{SO}_{4}$ molecules at a ratio $\Delta m / \Delta n$ of about unity, once the cluster is large enough for the effect of the $\mathrm{HSO}_{4}^{-}$or $\mathrm{NH}_{4}^{+}$ion to be neutralized in terms of its basicity or acidity (Figs. 4, 6a, 8a, $8 b)$. Therefore we would expect electrically neutral clusters to grow by the same ratio $\Delta m / \Delta n$ from the first bond formation onwards. At relatively low $\left[\mathrm{NH}_{3}\right]$, only negatively charged clusters were observed in our experiments, growing mainly by the uptake of $\mathrm{H}_{2} \mathrm{SO}_{4}$ molecules (Figs. 4, 6a), whereas positively charged clusters were not observed. Electrically neutral $\mathrm{NH}_{3}-\mathrm{H}_{2} \mathrm{SO}_{4}$ clusters must have been formed under these conditions as well, since new-particle formation occurred without any ions in the CLOUD chamber (Kirkby et al., 2011).

We could not measure electrically neutral $\mathrm{NH}_{3}-\mathrm{H}_{2} \mathrm{SO}_{4}$ clusters in this study. However, we studied their composition using ACDC computer simulations. ACDC is a kinetic collision and evaporation model addressing the formation dynamics and concentrations of molecular (charged and neutral) clusters (McGrath et al., 2012). In this study, we used ACDC to simulate the steady-state distribution of neutral clusters $\left(\mathrm{NH}_{3}\right)_{m} \cdot\left(\mathrm{H}_{2} \mathrm{SO}_{4}\right)_{n}$ up to $m=5$ and $n=5$, as described in Almeida et al. (2013), covering the different combinations of temperature, $\left[\mathrm{NH}_{3}\right]$ and $\left[\mathrm{H}_{2} \mathrm{SO}_{4}\right]$ probed during the experiments. Cluster evaporation rates were calculated from quantum chemical Gibbs free energies of formation of the clusters (Tables 1-3). The resulting simulated neutral clusters at steady state had an average $\mathrm{NH}_{3}$ content of up to $m=n$, dependent on $\left[\mathrm{NH}_{3}\right] /\left[\mathrm{H}_{2} \mathrm{SO}_{4}\right]$ 
Table 1. Evaporation rates from anion clusters, used for the ACDC model simulations. Clusters that were seen in the APi-TOF spectra are shown with the ${ }^{*}$.

\begin{tabular}{l|lll|c}
\hline Cluster & \multicolumn{3}{|c|}{ Highest evaporation rate $\left(\mathrm{s}^{-1}\right)$} & $\begin{array}{c}\text { Evaporating molecule/ } \\
\text { cluster }\end{array}$ \\
\hline $\mathrm{H}_{2} \mathrm{SO}_{4} \cdot \mathrm{HSO}_{4}^{-}$ & $-25^{\circ} \mathrm{C}$ & $5^{\circ} \mathrm{C}$ & $19^{\circ} \mathrm{C}$ & $\mathrm{H}_{2} \mathrm{SO}_{4}{ }^{*}$ \\
$\left(\mathrm{H}_{2} \mathrm{SO}_{4}\right)_{2} \cdot \mathrm{HSO}_{4}^{-}$ & $4.24 \times 10^{-22}$ & $8.07 \times 10^{-18}$ & $4.99 \times 10^{-16}$ & $\mathrm{H}_{2} \mathrm{SO}_{4}{ }^{*}$ \\
$\left(\mathrm{H}_{2} \mathrm{SO}_{4}\right)_{3} \cdot \mathrm{HSO}_{4}^{-}$ & $9.80 \times 10^{-3}$ & $1.97 \times 10^{-4}$ & $2.12 \times 10^{-3}$ & $\mathrm{H}_{2} \mathrm{SO}_{4}{ }^{*}$ \\
$\left(\mathrm{H}_{2} \mathrm{SO}_{4}\right)_{4} \cdot \mathrm{HSO}_{4}^{-}$ & 2.88 & $2.41 \times 10^{2}$ & $1.07 \times 10^{1}$ & $\mathrm{H}_{2} \mathrm{SO}_{4}{ }^{*}$ \\
$\mathrm{NH}_{3} \cdot \mathrm{HSO}_{4}^{-}$ & $2.40 \times 10^{10}$ & $1.52 \times 10^{11}$ & $3.15 \times 10^{11}$ & $\mathrm{NH}_{3}$ \\
$\mathrm{NH}_{3} \cdot \mathrm{H}_{2} \mathrm{SO}_{4} \cdot \mathrm{HSO}_{4}^{-}$ & $7.15 \times 10^{8}$ & $6.10 \times 10^{9}$ & $1.42 \times 10^{10}$ & $\mathrm{NH}_{3}$ \\
$\mathrm{NH}_{3} \cdot\left(\mathrm{H}_{2} \mathrm{SO}_{4}\right)_{2} \cdot \mathrm{HSO}_{4}^{-}$ & $2.03 \times 10^{2}$ & $1.45 \times 10^{4}$ & $7.86 \times 10^{4}$ & $\mathrm{NH}_{3}$ \\
$\mathrm{NH}_{3} \cdot\left(\mathrm{H}_{2} \mathrm{SO}_{4}\right)_{3} \cdot \mathrm{HSO}_{4}^{-}$ & $1.31 \times 10^{-2}$ & 1.78 & $1.24 \times 10^{1}$ & $\mathrm{NH}_{3}{ }^{*}$ \\
$\mathrm{NH}_{3} \cdot\left(\mathrm{H}_{2} \mathrm{SO}_{4}\right)_{4} \cdot \mathrm{HSO}_{4}^{-}$ & $2.56 \times 10^{-4}$ & $7.86 \times 10^{-2}$ & $7.56 \times 10^{-1}$ & $\mathrm{H}_{2} \mathrm{SO}_{4}{ }^{*}$ \\
$\left(\mathrm{NH}_{3}\right)_{2} \cdot\left(\mathrm{H}_{2} \mathrm{SO}_{4}\right)_{2} \cdot \mathrm{HSO}_{4}^{-}$ & $8.92 \times 10^{2}$ & $2.06 \times 10^{4}$ & $7.05 \times 10^{4}$ & $\mathrm{NH}_{3}$ \\
$\left(\mathrm{NH}_{3}\right)_{2} \cdot\left(\mathrm{H}_{2} \mathrm{SO}_{4}\right)_{3} \cdot \mathrm{HSO}_{4}^{-}$ & $1.97 \times 10^{-3}$ & $4.96 \times 10^{-1}$ & 4.44 & $\mathrm{NH}_{3}{ }^{*}$ \\
$\left(\mathrm{NH}_{3}\right)_{2} \cdot\left(\mathrm{H}_{2} \mathrm{SO}_{4}\right)_{4} \cdot \mathrm{HSO}_{4}^{-}$ & $4.31 \times 10^{-5}$ & $1.38 \times 10^{-2}$ & $1.36 \times 10^{-1}$ & $\mathrm{NH}_{3}{ }^{*}$ \\
$\left(\mathrm{NH}_{3}\right)_{3} \cdot\left(\mathrm{H}_{2} \mathrm{SO}_{4}\right)_{3} \cdot \mathrm{HSO}_{4}^{-}$ & 3.46 & $2.20 \times 10^{2}$ & $1.12 \times 10^{3}$ & $\mathrm{NH}_{3}$ \\
$\left(\mathrm{NH}_{3}\right)_{3} \cdot\left(\mathrm{H}_{2} \mathrm{SO}_{4}\right)_{4} \cdot \mathrm{HSO}_{4}^{-}$ & $7.21 \times 10^{-7}$ & $3.17 \times 10^{-4}$ & $3.52 \times 10^{-3}$ & $\mathrm{NH}_{3}{ }^{*}$ \\
$\left(\mathrm{NH}_{3}\right)_{4} \cdot\left(\mathrm{H}_{2} \mathrm{SO}_{4}\right)_{4} \cdot \mathrm{HSO}_{4}^{-}$ & $9.21 \times 10^{7}$ & $8.92 \times 10^{8}$ & $2.18 \times 10^{9}$ & $\mathrm{NH}_{3}$ \\
\hline
\end{tabular}

(Fig. 4). Note here certain differences in the composition when comparing the combined results for neutral, positive and negative clusters, in particular for the smallest ones. For example, the neutral dimers $(n=2)$ are stabilized mostly by one $\mathrm{NH}_{3}$ ligand (i.e., $\mathrm{NH}_{3} \cdot\left(\mathrm{H}_{2} \mathrm{SO}_{4}\right)_{2}$ ), which agrees with previous experimental and theoretical findings on the stabilization of the neutral dimer by $\mathrm{NH}_{3}$ or other bases (e.g., Ortega et al., 2014; Jen et al., 2014). On the other hand, the positive dimers mostly contain two $\mathrm{NH}_{3}$ ligands (i.e., $\left.\left(\mathrm{NH}_{3}\right)_{2} \cdot\left(\mathrm{H}_{2} \mathrm{SO}_{4}\right)_{2} \cdot \mathrm{NH}_{4}^{+}\right)$, whereas the anion dimer and trimer $(n=1,2)$ contain no $\mathrm{NH}_{3}$ at all (i.e., $\mathrm{H}_{2} \mathrm{SO}_{4} \cdot \mathrm{HSO}_{4}^{-}$and $\left.\left(\mathrm{H}_{2} \mathrm{SO}_{4}\right)_{2} \cdot \mathrm{HSO}_{4}^{-}\right)$. Still, all these compositions are consistent with our assertion that acid-base reactions are the underlying binding mechanism: the ammonium ion $\mathrm{NH}_{4}^{+}$(the conjugate acid of ammonia) acts as a weak acid, accommodating one additional $\mathrm{NH}_{3}$ compared to the neutral dimer. On the other hand, the anion dimer and trimer cannot accommodate any $\mathrm{NH}_{3}$ due to the presence of the bisulfate ion $\mathrm{HSO}_{4}^{-}$, the conjugate base of sulfuric acid, which acts as a stronger base than $\mathrm{NH}_{3}$, as described above. However, we expect the addition of more ligands, described by the ratio $\Delta m / \Delta n$, to be independent of the electric charge for cluster sizes large enough that the acid or base effect of $\mathrm{NH}_{4}^{+}$or in particular $\mathrm{HSO}_{4}^{-}$is neutralized.

We calculated the $\Delta m / \Delta n$ ratio for the simulated neutral clusters in the same way as for the measured data. However, a single neutral $\mathrm{H}_{2} \mathrm{SO}_{4}$ molecule was taken as the starting point for the simulated neutral clusters, due to the absence of the $\mathrm{HSO}_{4}^{-}$base. The results are shown as dashed lines in Fig. 6a. The results from the simulations of neutral clusters agreed with the measurements of charged clusters in some respects: a maximum $\Delta m / \Delta n$ of 1.2 to 1.3 was reached at high values of $\left[\mathrm{NH}_{3}\right] /\left[\mathrm{H}_{2} \mathrm{SO}_{4}\right]$, a higher maximum for lower temperatures, and $\Delta m / \Delta n$ decreased when $\left[\mathrm{NH}_{3}\right] /\left[\mathrm{H}_{2} \mathrm{SO}_{4}\right]<10$. Over the whole range, the simulations also reproduced the chief dependence of $\Delta m / \Delta n$ on the ratio $\left[\mathrm{NH}_{3}\right] /\left[\mathrm{H}_{2} \mathrm{SO}_{4}\right]$. At low values $\left[\mathrm{NH}_{3}\right] /\left[\mathrm{H}_{2} \mathrm{SO}_{4}\right]$, however, the simulated neutral clusters gained $\mathrm{NH}_{3}$ at a much higher rate than the measured negatively charged clusters. This discrepancy may arise for at least three reasons: (1) $\mathrm{H}_{2} \mathrm{O}$ molecules were not included in the model simulations, though they are abundant at $\mathrm{RH}=40 \%$ and may play a more important role at relatively low $\left[\mathrm{NH}_{3}\right]$; (2) small neutral clusters may indeed contain more $\mathrm{NH}_{3}$ than their negatively charged counterparts; (3) there is a barrier for the uptake of $\mathrm{NH}_{3}$ that is not modeled by ACDC. Reason 1 would imply that $\mathrm{H}_{2} \mathrm{O}$ molecules partially take over the role of stabilizing sulfuric acid clusters from $\mathrm{NH}_{3}$ at relatively low $\left[\mathrm{NH}_{3}\right]$. Qualitatively, this suggestion agrees with the expectation of $\mathrm{H}_{2} \mathrm{O}$ contributing to stabilization of sulfuric acid clusters, especially in the absence of $\mathrm{NH}_{3}$ (e.g., Vehkamäki et al., 2002), and of these clusters containing more $\mathrm{H}_{2} \mathrm{O}$ with less $\mathrm{NH}_{3}$ (Henschel et al., 2014). $\mathrm{As}_{2} \mathrm{O}$ was absent in the ACDC simulations, the clusters' $\mathrm{NH}_{3}$ content may thus be over-predicted. Reason 2 (more $\mathrm{NH}_{3}$ in neutral than in anion clusters) appears plausible on its own, as it would put the reliance on $\mathrm{NH}_{3}$ of neutral clusters between that of anion clusters (no $\mathrm{NH}_{3}$ required) and cation clusters (relatively much $\mathrm{NH}_{3}$ required). Reason 3 implicates a barrier for the uptake of $\mathrm{NH}_{3}$, but barrierless addition of $\mathrm{H}_{2} \mathrm{SO}_{4}$. The same conclusion was suggested above (Sect. 4.4) and by an independent study (Bzdek et al., 2013). ACDC assumes that collision partners instantly arrange to their minimum energy configuration, from which the new cluster may subsequently break 
Table 2. Evaporation rates from cation clusters, used for the ACDC model simulations. Clusters that were seen in the APi-TOF spectra are shown with the ${ }^{*}$.

\begin{tabular}{|c|c|c|c|c|}
\hline \multirow{2}{*}{ Cluster } & \multicolumn{3}{|c|}{ Highest evaporation rate $\left(\mathrm{s}^{-1}\right)$} & \multirow{2}{*}{$\begin{array}{l}\text { Evaporating molecule/ } \\
\text { cluster }\end{array}$} \\
\hline & $-25^{\circ} \mathrm{C}$ & $5^{\circ} \mathrm{C}$ & $19^{\circ} \mathrm{C}$ & \\
\hline $\mathrm{H}_{2} \mathrm{SO}_{4} \cdot \mathrm{NH}_{4}^{+}$ & $4.60 \times 10^{-4}$ & $3.30 \times 10^{-2}$ & $1.77 \times 10^{-1}$ & $\mathrm{H}_{2} \mathrm{SO}_{4} *$ \\
\hline$\left(\mathrm{H}_{2} \mathrm{SO} 4\right)_{2} \cdot \mathrm{NH}_{4}^{+}$ & $6.41 \times 10^{-2}$ & $1.40 \times 10^{1}$ & $1.17 \times 10^{2}$ & $\mathrm{H}_{2} \mathrm{SO}_{4} *$ \\
\hline $\mathrm{NH}_{3} \cdot \mathrm{NH}_{4}^{+}$ & $8.42 \times 10^{-9}$ & $2.36 \times 10^{-6}$ & $2.19 \times 10^{-5}$ & $\mathrm{NH}_{3} *$ \\
\hline $\mathrm{NH}_{3} \cdot \mathrm{H}_{2} \stackrel{4}{\mathrm{SO}_{4}} \cdot \mathrm{NH}_{4}^{+}$ & $2.71 \times 10^{-6}$ & $1.02 \times 10^{-3}$ & $1.06 \times 10^{-2}$ & $\mathrm{H}_{2} \mathrm{SO}_{4}^{*}$ \\
\hline $\mathrm{NH}_{3} \cdot\left(\mathrm{H}_{2} \mathrm{SO}_{4}\right)_{2} \cdot \mathrm{NH}_{4}^{+}$ & $1.96 \times 10^{-4}$ & $5.38 \times 10^{-2}$ & $4.95 \times 10^{-1}$ & $\mathrm{H}_{2} \mathrm{SO}_{4}{ }^{*}$ \\
\hline $\mathrm{NH}_{3} \cdot\left(\mathrm{H}_{2} \mathrm{SO}_{4}\right)_{3} \cdot \mathrm{NH}_{4}^{+}$ & $1.93 \times 10^{-1}$ & $2.68 \times 10^{1}$ & $1.88 \times 10^{2}$ & $\mathrm{H}_{2} \mathrm{SO}_{4}$ \\
\hline$\left(\mathrm{NH}_{3}\right)_{2} \cdot \mathrm{NH}_{4}^{+}$ & $6.88 \times 10^{1}$ & $2.75 \times 10^{3}$ & $1.18 \times 10^{4}$ & $\mathrm{NH}_{3}$ \\
\hline$\left(\mathrm{NH}_{3}\right)_{2} \cdot \mathrm{H}_{2} \mathrm{SO}_{4}^{4} \cdot \mathrm{NH}_{4}^{+}$ & 1.57 & $9.83 \times 10^{1}$ & $5.04 \times 10^{2}$ & $\mathrm{NH}_{3} *$ \\
\hline$\left(\mathrm{NH}_{3}\right)_{2} \cdot\left(\mathrm{H}_{2} \mathrm{SO}_{4}\right)_{2} \cdot \mathrm{NH}_{4}^{+}$ & $6.43 \times 10^{-10}$ & $5.41 \times 10^{-7}$ & $7.76 \times 10^{-6}$ & $\mathrm{NH}_{3} *$ \\
\hline$\left(\mathrm{NH}_{3}\right)_{2} \cdot\left(\mathrm{H}_{2} \mathrm{SO}_{4}\right)_{3} \cdot \mathrm{NH}_{4}^{+}$ & $1.01 \times 10^{-1}$ & $1.60 \times 10^{1}$ & $1.07 \times 10^{2}$ & $\mathrm{H}_{2} \mathrm{SO}_{4} *$ \\
\hline$\left(\mathrm{NH}_{3}\right)_{2} \cdot\left(\mathrm{H}_{2} \mathrm{SO}_{4}\right)_{4} \cdot \mathrm{NH}_{4}^{+}$ & 5.90 & $4.36 \times 10^{2}$ & $2.63 \times 10^{3}$ & $\mathrm{H}_{2} \mathrm{SO}_{4}$ \\
\hline$\left(\mathrm{NH}_{3}\right)_{3} \cdot\left(\mathrm{H}_{2} \mathrm{SO}_{4}\right)_{2} \cdot \mathrm{NH}_{4}^{+}$ & $4.34 \times 10^{1}$ & $2.00 \times 10^{3}$ & $9.10 \times 10^{3}$ & $\mathrm{NH}_{3}{ }^{*}$ \\
\hline$\left(\mathrm{NH}_{3}\right)_{3} \cdot\left(\mathrm{H}_{2} \mathrm{SO}_{4}\right)_{3} \cdot \mathrm{NH}_{4}^{+}$ & $3.57 \times 10^{-8}$ & $1.61 \times 10^{-5}$ & $1.99 \times 10^{-4}$ & $\mathrm{NH}_{3} *$ \\
\hline$\left(\mathrm{NH}_{3}\right)_{3} \cdot\left(\mathrm{H}_{2} \mathrm{SO}_{4}\right)_{4} \cdot \mathrm{NH}_{4}^{+}$ & $6.78 \times 10^{-2}$ & 8.21 & $5.44 \times 10^{1}$ & $\mathrm{H}_{2} \mathrm{SO}_{4} *$ \\
\hline$\left(\mathrm{NH}_{3}\right)_{4} \cdot\left(\mathrm{H}_{2} \mathrm{SO}_{4}\right)_{3} \cdot \mathrm{NH}_{4}^{+}$ & $6.00 \times 10^{1}$ & $2.73 \times 10^{3}$ & $1.23 \times 10^{4}$ & $\mathrm{NH}_{3}$ \\
\hline$\left(\mathrm{NH}_{3}\right)_{4} \cdot\left(\mathrm{H}_{2} \mathrm{SO}_{4}\right)_{4} \cdot \mathrm{NH}_{4}^{+}$ & $1.11 \times 10^{-4}$ & $3.01 \times 10^{-2}$ & $2.76 \times 10^{-1}$ & $\mathrm{NH}_{3} *$ \\
\hline$\left(\mathrm{NH}_{3}\right)_{4} \cdot\left(\mathrm{H}_{2} \mathrm{SO}_{4}\right)_{5} \cdot \mathrm{NH}_{4}^{+}$ & $2.26 \times 10^{-4}$ & $5.59 \times 10^{-2}$ & $4.92 \times 10^{-1}$ & $\mathrm{H}_{2} \mathrm{SO}_{4} *$ \\
\hline
\end{tabular}

apart. This assumption may be too simple for conditions of low $\left[\mathrm{NH}_{3}\right] /\left[\mathrm{H}_{2} \mathrm{SO}_{4}\right]$.

Neutral $\mathrm{NH}_{3}-\mathrm{H}_{2} \mathrm{SO}_{4}$ clusters were previously investigated experimentally by Hanson and Eisele (2002), in conditions close to those in this study, with $\left[\mathrm{NH}_{3}\right]$ between 100 and $800 \mathrm{pptv},\left[\mathrm{H}_{2} \mathrm{SO}_{4}\right]$ between 1 and $3 \times 10^{9} \mathrm{~cm}^{-3}$ (40 to $110 \mathrm{pptv}$ ), at temperatures from -8 to $+12^{\circ} \mathrm{C}$. The resulting $\left[\mathrm{NH}_{3}\right] /\left[\mathrm{H}_{2} \mathrm{SO}_{4}\right]$ ranged from about 2 to 13 , notably a range where we obtained few data. In that work, neutral clusters $\left(\mathrm{NH}_{3}\right)_{m} \cdot\left(\mathrm{H}_{2} \mathrm{SO}_{4}\right)_{n}$, up to $n=6$, were ionized by proton transfer to nitrate ions, yielding anion clusters $\left(\mathrm{NH}_{3}\right)_{m} \cdot\left(\mathrm{H}_{2} \mathrm{SO}_{4}\right)_{n-1} \cdot \mathrm{HSO}_{4}^{-}$, which were identified and counted using mass spectrometry. The $\mathrm{NH}_{3}$ content in their ion clusters ranged from $m=0$ to $n-1$, and was unaffected by changes in gas-phase $\left[\mathrm{NH}_{3}\right]$. They concluded that the ionization process may be ineffective for neutral clusters with an $\mathrm{NH}_{3}$ content of $m \geq n$, and also that it may lead to a loss of ligands, in particular of $\mathrm{NH}_{3}$. The former conclusion agrees with our simulation results of an $\mathrm{NH}_{3}$ content of small neutral clusters up to $m=n$ (Fig. 4), and it is roughly in line with our observation of anions with $m \geq n$ only starting from about $n \geq 6$ (Fig. 8b). The latter conclusion agrees qualitatively with the experimental and theoretical result in this study that the most prevalent (simulated) neutral cluster containing $n \mathrm{H}_{2} \mathrm{SO}_{4}$ contains one to three more $\mathrm{NH}_{3}$ ligands than the most prevalent corresponding (measured) anion cluster, containing $n-1 \mathrm{H}_{2} \mathrm{SO}_{4}$ (Fig. 4b). Interestingly, Hanson and Eisele (2002) also detected trimer anions $(n=3)$ including up to two $\mathrm{NH}_{3}$ ligands, whereas no trimer anions containing $\mathrm{NH}_{3}$ were found in our study (cf. Sect. 4.1). This difference is likely due the different production mechanism for their ion clusters, i.e., ionization of neutral clusters as opposed to growth of smaller already-charged clusters.

Note that the data presented in this work do not in fact allow conclusions on the details of the actual growth process of the clusters, but our discussion of the measured cluster size distributions here may have implied the assumption of a step-wise addition of single $\mathrm{H}_{2} \mathrm{SO}_{4}$ and $\mathrm{NH}_{3}$ molecules. In the ACDC simulations, $>99 \%$ of the modeled charged clusters indeed grow by the step-wise addition of single molecules, due to the small concentrations of the involved clusters. However, a major fraction of the modeled electrically neutral clusters formed by the recombination of charged clusters, if $\left[\mathrm{H}_{2} \mathrm{SO}_{4}\right]$ is low and temperature high (e.g., $\left[\mathrm{H}_{2} \mathrm{SO}_{4}\right] \leq 10^{6} \mathrm{~cm}^{-3}$ at $5^{\circ} \mathrm{C}$ ) (details in Olenius et al., 2013a).

\subsection{Comparison of $\mathrm{NH}_{3}-\mathrm{H}_{2} \mathrm{SO}_{4}$ clusters from CLOUD to ambient observations}

Negatively charged $\mathrm{NH}_{3}-\mathrm{H}_{2} \mathrm{SO}_{4}$ clusters are commonly observed during new-particle formation events at the boreal forest measurement site in Hyytiälä when using APi-TOF mass spectrometers (Kulmala et al., 2013; Schobesberger et al., 2013a). A typical anion mass spectrum obtained from those ambient APi-TOF measurements is presented in Fig. 8c, with the $\left(\mathrm{NH}_{3}\right)_{m} \cdot\left(\mathrm{H}_{2} \mathrm{SO}_{4}\right)_{n} \cdot \mathrm{HSO}_{4}^{-}$clusters shown colored. The majority of the larger ions (shown in grey) likely contain mainly a variety of oxidized organics, sometimes along with $\mathrm{H}_{2} \mathrm{SO}_{4}$ molecules (Schobesberger et al., 2013a; Ehn et al., 2012). However, most $\mathrm{H}_{2} \mathrm{SO}_{4}$ molecules in these anion clus- 
Table 3. Evaporation rates from neutral clusters, used for the ACDC model simulations.

\begin{tabular}{|c|c|c|c|c|}
\hline \multirow[t]{2}{*}{ Cluster } & \multicolumn{3}{|c|}{ Highest evaporation rate $\left(\mathrm{s}^{-1}\right)$} & \multirow{2}{*}{$\begin{array}{c}\text { Evaporating molecule } \\
\text { cluster }\end{array}$} \\
\hline & $-25^{\circ} \mathrm{C}$ & $5^{\circ} \mathrm{C}$ & $19^{\circ} \mathrm{C}$ & \\
\hline$\left(\mathrm{H}_{2} \mathrm{SO}_{4}\right)_{2}$ & $1.73 \times 10^{1}$ & $8.23 \times 10^{2}$ & $3.79 \times 10^{3}$ & $\mathrm{H}_{2} \mathrm{SO}_{4}$ \\
\hline$\left(\mathrm{H}_{2} \mathrm{SO}_{4}\right)_{3}$ & $4.42 \times 10^{2}$ & $2.15 \times 10^{4}$ & $1.00 \times 10^{5}$ & $\mathrm{H}_{2} \mathrm{SO}_{4}$ \\
\hline$\left(\mathrm{H}_{2} \mathrm{SO}_{4}\right)_{4}$ & $1.17 \times 10^{2}$ & $4.54 \times 10^{3}$ & $1.92 \times 10^{4}$ & $\mathrm{H}_{2} \mathrm{SO}_{4}$ \\
\hline$\left(\mathrm{H}_{2} \mathrm{SO}_{4}\right)_{5}$ & $1.85 \times 10^{2}$ & $8.15 \times 10^{3}$ & $3.63 \times 10^{4}$ & $\mathrm{H}_{2} \mathrm{SO}_{4}$ \\
\hline $\mathrm{NH}_{3} \cdot \mathrm{H}_{2} \mathrm{SO}_{4}$ & $1.50 \times 10^{2}$ & $4.74 \times 10^{3}$ & $1.85 \times 10^{4}$ & $\mathrm{H}_{2} \mathrm{SO}_{4}$ \\
\hline $\mathrm{NH}_{3} \cdot\left(\mathrm{H}_{2} \mathrm{SO}_{4}\right)_{2}$ & $3.38 \times 10^{-6}$ & $1.21 \times 10^{-3}$ & $1.25 \times 10^{-2}$ & $\mathrm{NH}_{3}$ \\
\hline $\mathrm{NH}_{3} \cdot\left(\mathrm{H}_{2} \mathrm{SO}_{4}\right)_{3}$ & $3.11 \times 10^{-1}$ & $3.02 \times 10^{1}$ & $1.84 \times 10^{2}$ & $\mathrm{H}_{2} \mathrm{SO}_{4}$ \\
\hline $\mathrm{NH}_{3} \cdot\left(\mathrm{H}_{2} \mathrm{SO}_{4}\right)_{4}$ & 5.91 & $6.03 \times 10^{2}$ & $3.75 \times 10^{3}$ & $\mathrm{H}_{2} \mathrm{SO}_{4}$ \\
\hline $\mathrm{NH}_{3} \cdot\left(\mathrm{H}_{2} \mathrm{SO}_{4}\right)_{5}$ & $1.87 \times 10^{2}$ & $1.10 \times 10^{4}$ & $5.48 \times 10^{4}$ & $\mathrm{H}_{2} \mathrm{SO}_{4}$ \\
\hline$\left(\mathrm{NH}_{3}\right)_{2}$ & $4.43 \times 10^{12}$ & $6.09 \times 10^{12}$ & $6.87 \times 10^{12}$ & $\mathrm{NH}_{3}$ \\
\hline$\left(\mathrm{NH}_{3}\right)_{2} \cdot \mathrm{H}_{2} \mathrm{SO}_{4}$ & $4.17 \times 10^{4}$ & $7.97 \times 10^{5}$ & $2.56 \times 10^{6}$ & $\mathrm{NH}_{3}$ \\
\hline$\left(\mathrm{NH}_{3}\right)_{2} \cdot\left(\mathrm{H}_{2} \mathrm{SO}_{4}\right)_{2}$ & 2.61 & $1.76 \times 10^{2}$ & $9.30 \times 10^{2}$ & $\mathrm{NH}_{3}$ \\
\hline$\left(\mathrm{NH}_{3}\right)_{2} \cdot\left(\mathrm{H}_{2} \mathrm{SO}_{4}\right)_{3}$ & $1.37 \times 10^{-5}$ & $3.84 \times 10^{-3}$ & $3.59 \times 10^{-2}$ & $\mathrm{NH}_{3}$ \\
\hline$\left(\mathrm{NH}_{3}\right)_{2} \cdot\left(\mathrm{H}_{2} \mathrm{SO}_{4}\right)_{4}$ & $2.72 \times 10^{-2}$ & 5.43 & $3.92 \times 10^{1}$ & $\mathrm{H}_{2} \mathrm{SO}_{4}$ \\
\hline$\left(\mathrm{NH}_{3}\right)_{2} \cdot\left(\mathrm{H}_{2} \mathrm{SO}_{4}\right)_{5}$ & $6.55 \times 10^{1}$ & $3.58 \times 10^{3}$ & $1.96 \times 10^{4}$ & $\mathrm{H}_{2} \mathrm{SO}_{4}$ \\
\hline$\left(\mathrm{NH}_{3}\right)_{3}$ & $3.60 \times 10^{12}$ & $1.31 \times 10^{13}$ & $2.18 \times 10^{13}$ & $\mathrm{NH}_{3}$ \\
\hline$\left(\mathrm{NH}_{3}\right)_{3} \cdot \mathrm{H}_{2} \mathrm{SO}_{4}$ & $1.72 \times 10^{8}$ & $1.72 \times 10^{9}$ & $4.28 \times 10^{9}$ & $\mathrm{NH}_{3}$ \\
\hline$\left(\mathrm{NH}_{3}\right)_{3} \cdot\left(\mathrm{H}_{2} \mathrm{SO}_{4}\right)_{2}$ & $2.77 \times 10^{4}$ & $7.17 \times 10^{5}$ & $2.59 \times 10^{6}$ & $\mathrm{NH}_{3}$ \\
\hline$\left(\mathrm{NH}_{3}\right)_{3} \cdot\left(\mathrm{H}_{2} \mathrm{SO}_{4}\right)_{3}$ & $2.24 \times 10^{-4}$ & $4.60 \times 10^{-2}$ & $3.77 \times 10^{-1}$ & $\mathrm{NH}_{3}$ \\
\hline$\left(\mathrm{NH}_{3}\right)_{3} \cdot\left(\mathrm{H}_{2} \mathrm{SO}_{4}\right)_{4}$ & $4.30 \times 10^{-6}$ & $2.10 \times 10^{-3}$ & $2.45 \times 10^{-2}$ & $\mathrm{H}_{2} \mathrm{SO}_{4}$ \\
\hline$\left(\mathrm{NH}_{3}\right)_{3} \cdot\left(\mathrm{H}_{2} \mathrm{SO}_{4}\right)_{5}$ & $4.59 \times 10^{-3}$ & $7.83 \times 10^{-1}$ & 5.95 & $\mathrm{H}_{2} \mathrm{SO}_{4}$ \\
\hline$\left(\mathrm{NH}_{3}\right)_{4}$ & $9.07 \times 10^{11}$ & $2.35 \times 10^{12}$ & $3.41 \times 10^{12}$ & $\left(\mathrm{NH}_{3}\right)_{2}$ \\
\hline$\left(\mathrm{NH}_{3}\right)_{4} \cdot \mathrm{H}_{2} \mathrm{SO}_{4}$ & $1.36 \times 10^{7}$ & $1.38 \times 10^{8}$ & $3.47 \times 10^{8}$ & $\mathrm{NH}_{3}$ \\
\hline$\left(\mathrm{NH}_{3}\right)_{4} \cdot\left(\mathrm{H}_{2} \mathrm{SO}_{4}\right)_{2}$ & $2.46 \times 10^{6}$ & $3.33 \times 10^{7}$ & $9.31 \times 10^{7}$ & $\mathrm{NH}_{3}$ \\
\hline$\left(\mathrm{NH}_{3}\right)_{4} \cdot\left(\mathrm{H}_{2} \mathrm{SO}_{4}\right)_{3}$ & $4.45 \times 10^{3}$ & $1.46 \times 10^{5}$ & $5.81 \times 10^{5}$ & $\mathrm{NH}_{3}$ \\
\hline$\left(\mathrm{NH}_{3}\right)_{4} \cdot\left(\mathrm{H}_{2} \mathrm{SO}_{4}\right)_{4}$ & $5.87 \times 10^{-1}$ & $3.75 \times 10^{1}$ & $1.94 \times 10^{2}$ & $\mathrm{NH}_{3}$ \\
\hline$\left(\mathrm{NH}_{3}\right)_{4} \cdot\left(\mathrm{H}_{2} \mathrm{SO}_{4}\right)_{5}$ & $5.97 \times 10^{-4}$ & $8.87 \times 10^{-2}$ & $6.41 \times 10^{-1}$ & $\mathrm{NH}_{3}$ \\
\hline$\left(\mathrm{NH}_{3}\right)_{5} \cdot\left(\mathrm{H}_{2} \mathrm{SO}_{4}\right)_{4}$ & 7.49 & $8.89 \times 10^{2}$ & $5.91 \times 10^{3}$ & $\mathrm{NH}_{3}$ \\
\hline$\left(\mathrm{NH}_{3}\right)_{5} \cdot\left(\mathrm{H}_{2} \mathrm{SO}_{4}\right)_{5}$ & $1.82 \times 10^{-7}$ & $1.17 \times 10^{-4}$ & $1.52 \times 10^{-3}$ & $\mathrm{NH}_{3}$ \\
\hline
\end{tabular}

ters are found in the $\left(\mathrm{NH}_{3}-\right) \mathrm{H}_{2} \mathrm{SO}_{4}$ clusters. Amines are present in some of these clusters as well, but most of the larger of these clusters $(n>3)$ contain only $\mathrm{NH}_{3}$ and $\mathrm{H}_{2} \mathrm{SO}_{4}$.

Figures $4 \mathrm{~b}, 6 \mathrm{a}$ and 7 include a comparison of the CLOUD results with the observations of negatively charged $\mathrm{NH}_{3}-$ $\mathrm{H}_{2} \mathrm{SO}_{4}$ clusters during new-particle formation events in the boreal forest during springtime. The ambient measurements were made under conditions comparable to those covered by the CLOUD experiments, with mean values of $4^{\circ} \mathrm{C}$ for the temperature and $47 \%$ for $\mathrm{RH}$. The $\mathrm{NH}_{3}-\mathrm{H}_{2} \mathrm{SO}_{4}$ clusters from the boreal forest measurements always showed a high $\mathrm{NH}_{3}$ content, comparable to clusters observed at CLOUD, and with $\Delta m / \Delta n>1$. The $\left[\mathrm{NH}_{3}\right] /\left[\mathrm{H}_{2} \mathrm{SO}_{4}\right]$ ratios measured in the boreal forest at the same times were relatively high as well, with $\left[\mathrm{NH}_{3}\right]$ ranging from 28 to $134 \mathrm{pptv}$ (0.8 to $3.6 \times 10^{9} \mathrm{~cm}^{-3}$ ) and $\left[\mathrm{H}_{2} \mathrm{SO}_{4}\right]$ from 0.5 to $2.1 \times 10^{7} \mathrm{~cm}^{-3}$. In these terms, therefore, the ambient observations fully agree with the findings from the laboratory experiments at CLOUD (Figs. 4b, 6a, 7). That specific $\left[\mathrm{H}_{2} \mathrm{SO}_{4}\right]$ range is well within the values of $\left[\mathrm{H}_{2} \mathrm{SO}_{4}\right]$ during new-particle formation events recorded around the world, those values ranging from about $10^{5}$ to $10^{8} \mathrm{~cm}^{-3}$ (e.g., Kuang et al., 2008). The $\left[\mathrm{NH}_{3}\right]$ range observed during the boreal forest events appears on the low side, as it is commonly exceeded by measurements of $\left[\mathrm{NH}_{3}\right]$ at many other locations (Ziereis and Arnold, 1986; Janson et al., 2001; Riipinen et al., 2007; Gong et al., 2011; Osada et al., 2011). Therefore, our results suggest that atmospheric $\mathrm{NH}_{3}-\mathrm{H}_{2} \mathrm{SO}_{4}$ clusters forming in the warm boundary layer always feature the maximum $\mathrm{NH}_{3}$ content (i.e., $\Delta m / \Delta n>1$ ) as most locations of boundary layer observations are likely saturated in $\left[\mathrm{NH}_{3}\right]$ with respect to the growth of $\mathrm{NH}_{3}-\mathrm{H}_{2} \mathrm{SO}_{4}$ clusters.

Binary $\mathrm{H}_{2} \mathrm{O}-\mathrm{H}_{2} \mathrm{SO}_{4}$ new-particle formation (i.e., with negligible contribution of $\mathrm{NH}_{3}$ ) can only occur in conditions of sufficiently low $\left[\mathrm{NH}_{3}\right] /\left[\mathrm{H}_{2} \mathrm{SO}_{4}\right]$ or at low temperatures. Therefore, binary $\mathrm{H}_{2} \mathrm{O}-\mathrm{H}_{2} \mathrm{SO}_{4}$ new-particle formation must be largely restricted to the free troposphere, and relatively cold parts are preferred. Low temperatures can also facilitate 
appreciable particle formation rates at atmospherically relevant levels of $\left[\mathrm{H}_{2} \mathrm{SO}_{4}\right]$ without the necessity of additional participating vapors (Kirkby et al., 2011).

\section{Summary and conclusions}

We have presented a comprehensive description of the composition of $\mathrm{NH}_{3}-\mathrm{H}_{2} \mathrm{SO}_{4}$ clusters as a function of environmental variables, in particular concentrations of precursor vapors $\left(\left[\mathrm{NH}_{3}\right]\right.$ and $\left.\left[\mathrm{H}_{2} \mathrm{SO}_{4}\right]\right)$ and temperature. A wide range of atmospherically relevant conditions were covered, with $\left[\mathrm{NH}_{3}\right]$ ranging from $<2$ to $1400 \mathrm{pptv},\left[\mathrm{H}_{2} \mathrm{SO}_{4}\right]$ from $3.3 \times 10^{6}$ to $1.4 \times 10^{9} \mathrm{~cm}^{-3}(0.1$ to $56 \mathrm{pptv})$, and temperature from $-25^{\circ} \mathrm{C}$ to $+20^{\circ} \mathrm{C}$. Our ion cluster measurements covered the size range between 1 and $2 \mathrm{~nm}$ (mobilityequivalent diameters).

We found that the ratio $\left[\mathrm{NH}_{3}\right] /\left[\mathrm{H}_{2} \mathrm{SO}_{4}\right]$ principally determines the composition of the measured $\mathrm{NH}_{3}-\mathrm{H}_{2} \mathrm{SO}_{4}$ ion clusters, with temperature in a secondary role. Positively charged clusters are only observed from a sufficiently high ratio $\left[\mathrm{NH}_{3}\right] /\left[\mathrm{H}_{2} \mathrm{SO}_{4}\right]$ upwards. From a ratio $\left[\mathrm{NH}_{3}\right] /\left[\mathrm{H}_{2} \mathrm{SO}_{4}\right]$ of about 10 up to at least 500 , both negatively and positively charged clusters grow by the addition of on average 1 to $1.4 \mathrm{NH}_{3}$ molecules per each addition of an $\mathrm{H}_{2} \mathrm{SO}_{4}$ molecule. The resultant $\mathrm{NH}_{3} / \mathrm{H}_{2} \mathrm{SO}_{4}$ molar ratios are remarkably close to that of ammonium bisulfate (with an $\mathrm{NH}_{3} / \mathrm{H}_{2} \mathrm{SO}_{4}$ molar ratio of unity). On the other hand, pure binary $\mathrm{H}_{2} \mathrm{O}-\mathrm{H}_{2} \mathrm{SO}_{4}$ clusters (without contribution of $\mathrm{NH}_{3}$ ) only form at values of $\left[\mathrm{NH}_{3}\right] /\left[\mathrm{H}_{2} \mathrm{SO}_{4}\right]$ smaller than about 0.1 (depending also on temperature). In our experiments, these binary clusters were only observed as negatively charged $\mathrm{H}_{2} \mathrm{SO}_{4}$ clusters. In the ambient atmosphere, their formation must be largely restricted to higher regions of the troposphere, where $\mathrm{NH}_{3}$ concentrations are low.

A detailed comparison of model results probing the growth of negative, positive and neutral $\mathrm{NH}_{3}-\mathrm{H}_{2} \mathrm{SO}_{4}$ clusters is presented in Olenius et al. (2013a). So far, the quantum chemical data used to calculate the cluster evaporation rates restricted those model simulations to clusters containing up to 10 molecules, whereas the APi-TOF measurements could measure negatively and positively charged clusters up to clusters containing $>50 \mathrm{NH}_{3}$ and $\mathrm{H}_{2} \mathrm{SO}_{4}$ molecules. The model simulations of neutral clusters and APi-TOF measurements of charged clusters are consistent and in good agreement with each other for cases of $\left[\mathrm{NH}_{3}\right] /\left[\mathrm{H}_{2} \mathrm{SO}_{4}\right]>10$. Under these conditions, electrically neutral $\mathrm{NH}_{3}-\mathrm{H}_{2} \mathrm{SO}_{4}$ clusters are also likely to grow principally by adding, on average, 1 to $1.4 \mathrm{NH}_{3}$ molecules for each added $\mathrm{H}_{2} \mathrm{SO}_{4}$ molecule. Note that the recombination of anion and cation clusters can also contribute to the population of neutral clusters (Olenius et al., 2013a; Kontkanen et al., 2013).
In combination, measurement and model results strongly suggest that acid-base interactions are the dominant clustering mechanism for all $\mathrm{NH}_{3}-\mathrm{H}_{2} \mathrm{SO}_{4}$ clusters. These interactions allow for the initial formation of clusters and facilitate additional inter-molecular bonds as the clusters grow to $2 \mathrm{~nm}$ in size and larger, i.e., sizes that are nowadays accessible by condensation particle counters (Lehtipalo et al., 2014). The presence of an electric charge implies a missing or extra proton, i.e., the creation of a conjugate base or acid. In particular, the (strong) basic properties of $\mathrm{HSO}_{4}^{-}$have an important impact on the composition of the small negatively charged clusters. We identified the $\mathrm{HSO}_{5}^{-}$ion as an important alternative ion in these clusters for the conditions in the CLOUD chamber. It appears to be slightly less basic than $\mathrm{HSO}_{4}^{-}$and similarly affects cluster composition. Besides the stabilizing effect of the electric charge on the cluster, the property of $\mathrm{HSO}_{4}^{-}$(or $\mathrm{HSO}_{5}^{-}$) as a Lewis base is probably crucial to the enhancements of particle formation rates attributed to ions (Kirkby et al., 2011).

In the atmospheric boundary layer, the composition of formed $\mathrm{NH}_{3}-\mathrm{H}_{2} \mathrm{SO}_{4}$ clusters will mostly be in the saturation regime that we observed with respect to the clusters' $\mathrm{NH}_{3}$ content; that is, they will be seen growing by the addition of on average slightly more than one $\mathrm{NH}_{3}$ molecule per added $\mathrm{H}_{2} \mathrm{SO}_{4}$ molecule. This is because $\mathrm{H}_{2} \mathrm{SO}_{4}$ concentrations in the boundary layer are comparatively low, mostly at sub-pptv levels, leading to typical vapor concentration ratios $\left[\mathrm{NH}_{3}\right] /\left[\mathrm{H}_{2} \mathrm{SO}_{4}\right]$ of larger than 10. Ambient APi-TOF measurements during new-particle formation events in the Finnish boreal forest indeed confirm this prediction.

Another general requirement for the formation of $\mathrm{NH}_{3}-$ $\mathrm{H}_{2} \mathrm{SO}_{4}$ clusters is the sufficiently low abundance of compounds competing with $\mathrm{NH}_{3}$ in forming clusters with $\mathrm{H}_{2} \mathrm{SO}_{4}$. One such class of compounds has been shown to be amines, in particular dimethylamine (Bzdek et al., 2011; Almeida et al., 2013). The measurements at the boreal forest measurement site in Hyytiälä have shown that large $\mathrm{NH}_{3}-$ $\mathrm{H}_{2} \mathrm{SO}_{4}$ ion clusters do not usually contain amines (Schobesberger et al., 2013a). This observation suggests relatively low amine concentrations in the boreal forest environment. In fact, the prevalence of $\mathrm{NH}_{3}$ over amines is similar to the observations in the CLOUD chamber at the presence of contaminant levels of amines, indicating ambient dimethylamine concentrations in the boreal forest of $<1$ pptv.

What remains unsolved is the exact role of $\mathrm{NH}_{3}-\mathrm{H}_{2} \mathrm{SO}_{4}$ clusters, and $\mathrm{NH}_{3}$ in general, in the initial steps of the boundary layer events of new-particle formation and growth that are frequently observed in the Finnish boreal forest and elsewhere (Kulmala et al., 2004b). Such clusters have been observed, but laboratory experiments suggest that they are not stable enough to fully account for the bulk of boundary layer particle formation (Kirkby et al., 2011). Other experiments conclude that clusters of two to three $\mathrm{H}_{2} \mathrm{SO}_{4}$ molecules plus a mix of basic molecules $\left(\mathrm{NH}_{3}\right.$ and amines) can in fact ac- 
count for particle formation in polluted conditions (Chen et al., 2012).

At least in clean environments rich in $\alpha$-pinene, such as boreal forests, recent experimental evidence hints at an important role of highly oxidized organic compounds with extremely low volatility in the very first steps of boundarylayer particle formation (Kulmala et al., 1998; Schobesberger et al., 2013a; Ehn et al., 2014; Riccobono et al., 2014). These organic compounds probably feature several functional groups that facilitate hydrogen bonds with each other and with $\mathrm{H}_{2} \mathrm{SO}_{4}$ molecules, in the same way as the bonds between $\mathrm{H}_{2} \mathrm{SO}_{4}$ and $\mathrm{NH}_{3}$ (Donahue et al., 2013). However, the inclusion of dimethylamine in these sub- $2 \mathrm{~nm}$ clusters has been observed as well (Riccobono et al., 2014). Our ambient observations in the boreal forest suggest that a large fraction of $\mathrm{H}_{2} \mathrm{SO}_{4}$ molecules in sub- $2 \mathrm{~nm}$ clusters are found in clusters with $\mathrm{NH}_{3}$. Therefore, it seems very likely that mixed sub- $2 \mathrm{~nm} \mathrm{NH} \mathrm{NH}_{3}-\mathrm{H}_{2} \mathrm{SO}_{4}$-organics clusters are also stable and indeed commonly contribute to particle formation in the boreal forest.

The measurement results presented here substantially extend our knowledge on how $\mathrm{NH}_{3}$ and $\mathrm{H}_{2} \mathrm{SO}_{4}$ interact in detail when forming and growing clusters under atmospheric conditions. The results are in general agreement with results from model simulations (e.g., Olenius et al., 2013a), as well as with previous experimental work (e.g., Hanson and Eisele, 2002; Bzdek et al., 2011; Froyd and Lovejoy, 2012; Bzdek et al., 2013). Altogether, we are moving closer to gaining a more complete and detailed understanding of this subject. The most important contribution of the present study is a detailed examination of cluster compositions under a wide range of atmospherically relevant conditions, and experimentally covering the whole sub- $2 \mathrm{~nm}$ size range for charged clusters. Supported by simulations of cluster population dynamics, the results also allow for inferences to be made on electrically neutral $\mathrm{NH}_{3}-\mathrm{H}_{2} \mathrm{SO}_{4}$ clusters.

Acknowledgements. We wish to thank Tinja Olenius for running the ACDC model calculations presented in this study, as well as for commenting on the manuscript. Tinja Olenius, Joonas Merikanto, Theo Kurtén, Ilona Riipinen, Henning Henschel, Oona Kupiainen-Määttä and Hanna Vehkamäki are acknowledged for several useful and insightful discussions. CERN's support of CLOUD with important technical and financial resources and provision of a particle beam from the Proton Synchrotron is gratefully acknowledged. This research was funded by the European Commission 7th Framework Programme (Marie Curie Initial Training Network "CLOUD-ITN," grant 215072), the European Research Council (ERC) Advanced Grant Atmospheric nucleation: from molecular to global scale (ATMNUCLE) (grant 227463), the Academy of Finland via the Centre of Excellence Programme (project 1118615) and grant 1133872, the Swiss National Science Foundation (projects 200020_135307 and 206620_141278), the German Federal Ministry of Education and Research (project 01LK0902A), the Austrian Science Fund (projects P19546 and L593), the Portuguese Foundation for Science and Technology (project CERN/FP/116387/2010), and the US National Science Foundation (grants AGS1136479 and CHE1012293).

Edited by: F. McNeill

\section{References}

Almeida, J., Schobesberger, S., Kürten, A., Ortega, I. K., Kupiainen-Määttä, O., Praplan, A. P., Adamov, A., Amorim, A., Bianchi, F., Breitenlechner, M., David, A., Dommen, J., Donahue, N. M., Downard, A., Dunne, E., Duplissy, J., Ehrhart, S., Flagan, R. C., Franchin, A., Guida, R., Hakala, J., Hansel, A., Heinritzi, M., Henschel, H., Jokinen, T., Junninen, H., Kajos, M., Kangasluoma, J., Keskinen, H., Kupc, A., Kurtén, T., Kvashin, A. N., Laaksonen, A., Lehtipalo, K., Leiminger, M., Leppä, J., Loukonen, V., Makhmutov, V., Mathot, S., McGrath, M. J., Nieminen, T., Olenius, T., Onnela, A., Petäjä, T., Riccobono, F., Riipinen, I., Rissanen, M., Rondo, L., Ruuskanen, T., Santos, F. D., Sarnela, N., Schallhart, S., Schnitzhofer, R., Seinfeld, J. H., Simon, M., Sipilä, M., Stozhkov, Y., Stratmann, F., Tomé, A., Tröstl, J., Tsagkogeorgas, G., Vaattovaara, P., Viisanen, Y., Virtanen, A., Vrtala, A., Wagner, P. E., Weingartner, E., Wex, H., Williamson, C., Wimmer, D., Ye, P., Yli-Juuti, T., Carslaw, K. S., Kulmala, M., Curtius, J., Baltensperger, U., Worsnop, D. R., Vehkamäki, H., and Kirkby, J.: Molecular understanding of sulphuric acid-amine particle nucleation in the atmosphere, Nature, 502, 359-363, 2013.

Ball, S. M., Hanson, D. R., Eisele, F. L., and McMurry, P. H.: Laboratory studies of particle nucleation: Initial results for $\mathrm{H}_{2} \mathrm{SO}_{4}$, $\mathrm{H}_{2} \mathrm{O}$, and $\mathrm{NH}_{3}$ vapors, J. Geophys. Res., 104, 23709-23718, 1999.

Bianchi, F., Dommen, J., Mathot, S., and Baltensperger, U.: Online determination of ammonia at low pptv mixing ratios in the CLOUD chamber, Atmos. Meas. Tech., 5, 1719-1725, doi:10.5194/amt-5-1719-2012, 2012.

Bianchi, F., Praplan, A. P., Sarnela, N., Dommen, J., Kürten, A., Ortega, I. K., Schobesberger, S., Junninen, H., Simon, M., Tröstl, J., Jokinen, T., Sipilä, M., Adamov, A., Amorim, A., Almeida, J., Breitenlechner, M., Duplissy, J., Ehrhart, S., Flagan, R. C., Franchin, A., Hakala, J., Hansel, A., Heinritzi, M., Kangasluoma, J., Keskinen, H., Kim, J., Kirkby, J., Laaksonen, A., Lawler, M. J., Lehtipalo, K., Leiminger, M., Makhmutov, V., Mathot, S., Onnela, A., Petäjá, T., Riccobono, F., Rissanen, M. P., Rondo, L., Tomé, A. n., Virtanen, A., Viisanen, Y., Williamson, C., Wimmer, D., Winkler, P. M., Ye, P., Curtius, J., Kulmala, M., Worsnop, D. R., Donahue, N. M., and Baltensperger, U.: Insight into acid-base nucleation experiments by comparison of the chemical composition of positive, negative and neutral clusters, Env. Sci. Tech., in press, doi:10.1021/es502380b, 2014.

Bzdek, B. R., Ridge, D. P., and Johnston, M. V.: Size-dependent reactions of ammonium bisulfate clusters with dimethylamine, J. Phys. Chem. A, 114, 11638-11644, 2010.

Bzdek, B. R., Ridge, D. P., and Johnston, M. V.: Amine reactivity with charged sulfuric acid clusters, Atmos. Chem. Phys., 11, 8735-8743, doi:10.5194/acp-11-8735-2011, 2011.

Bzdek, B. R., DePalma, J. W., Ridge, D. P., Laskin, J., and Johnston, M. V.: Fragmentation energetics of clusters relevant to atmo- 
spheric new particle formation, J. Am. Chem. Soc., 135, 32763285, 2013.

Chang, I.-H., Lee, C.-G., and Lee, D. S.: Development of an automated method for simultaneous determination of low molecular weight aliphatic amines and ammonia in ambient air by diffusion scrubber coupled to ion chromatography, Anal. Chem., 75, 6141-6146, 2003.

Chen, M., Titcombe, M., Jiang, J., Jen, C., Kuang, C., Fischer, M. L., Eisele, F. L., Siepmann, J. I., Hanson, D. R., Zhao, J., and McMurry, P. H.: Acid-base chemical reaction model for nucleation rates in the polluted atmospheric boundary layer, Proc. Natl. Acad. Sci. USA, 109, 18713-18718, 2012.

Coffman, D. J. and Hegg, D. A.: A preliminary study of the effect of ammonia on particle nucleation in the marine boundary layer, J. Geophys. Res., 100, 7147-7160, 1995.

DePalma, J. W., Bzdek, B. R., Doren, D. J., and Johnston, M. V.: Structure and energetics of nanometer size clusters of sulfuric acid with ammonia and dimethylamine, J. Phys. Chem. A, 116, 1030-1040, 2012.

DePalma, J. W., Doren, D. J., and Johnston, M. V.: Formation and growth of molecular clusters containing sulfuric acid, water, ammonia, and dimethylamine, J. Phys. Chem. A, 118, 5464-5473, 2014.

Donahue, N. M., Chuang, W., Ortega, I. K., Riipinen, I., Riccobono, F., Schobesberger, S., Dommen, J., Kulmala, M., Worsnop, D. R., and Vehkamäki, H.: How do organic vapors contribute to newparticle formation?, Farad. Discuss., 165, 91-104, 2013.

Ehn, M., Junninen, H., Petäjä, T., Kurtén, T., Kerminen, V.M., Schobesberger, S., Manninen, H. E., Ortega, I. K., Vehkamäki, H., Kulmala, M., and Worsnop, D. R.: Composition and temporal behavior of ambient ions in the boreal forest, Atmos. Chem. Phys., 10, 8513-8530, doi:10.5194/acp-10-85132010, 2010.

Ehn, M., Junninen, H., Schobesberger, S., Manninen, H. E., Franchin, A., Sipilä, M., Petäjä, T., Kerminen, V.-M., Tammet, H., Mirme, A., Mirme, S., Hõrrak, U., Kulmala, M., and Worsnop, D. R.: An instrumental comparison of mobility and mass measurements of atmospheric small ions, Aerosol Sci. Tech., 45, 522-532, 2011.

Ehn, M., Kleist, E., Junninen, H., Petäjä, T., Lönn, G., Schobesberger, S., Dal Maso, M., Trimborn, A., Kulmala, M., Worsnop, D. R., Wahner, A., Wildt, J., and Mentel, Th. F.: Gas phase formation of extremely oxidized pinene reaction products in chamber and ambient air, Atmos. Chem. Phys., 12, 51135127, doi:10.5194/acp-12-5113-2012, 2012.

Ehn, M., Thornton, J. A., Kleist, E., Sipila, M., Junninen, H., Pullinen, I., Springer, M., Rubach, F., Tillmann, R., Lee, B., LopezHilfiker, F., Andres, S., Acir, I.-H., Rissanen, M., Jokinen, T., Schobesberger, S., Kangasluoma, J., Kontkanen, J., Nieminen, T., Kurtén, T., Nielsen, L. B., Jørgensen, S., Kjaergaard, H. G., Canagaratna, M., Maso, M. D., Berndt, T., Petäjä, T., Wahner, A., Kerminen, V.-M., Kulmala, M., Worsnop, D. R., Wildt, J., and Mentel, T. F.: A large source of low-volatility secondary organic aerosol, Nature, 506, 476-479, 2014.

Eisele, F. L. and Hanson, D. R.: First measurements of prenucleation molecular clusters, J. Phys. Chem. A, 104, 830-836, 2000.

Froyd, K. D. and Lovejoy, E. R.: Bond energies and structures of ammonia-sulfuric acid positive cluster ions, J. Phys. Chem. A, 116, 5886-5899, 2012.
Ghan, S. J., Smith, S. J., Wang, M., Zhang, K., Pringle, K., Carslaw, K., Pierce, J., Bauer, S., and Adams, P.: A simple model of global aerosol indirect effects, J. Geophys. Res. Atmos., 118, 66886707, 2013.

Gong, L., Lewicki, R., Griffin, R. J., Flynn, J. H., Lefer, B. L., and Tittel, F. K.: Atmospheric ammonia measurements in Houston, TX using an external-cavity quantum cascade laser-based sensor, Atmos. Chem. Phys., 11, 9721-9733, doi:10.5194/acp-11-97212011, 2011.

Hanson, D. R. and Eisele, F. L.: Measurement of prenucleation molecular clusters in the $\mathrm{NH}_{3}, \mathrm{H}_{2} \mathrm{SO}_{4}, \mathrm{H}_{2} \mathrm{O}$ system, J. Geophys. Res., 107, AAC 10-11-AAC 10-18, 2002.

Hari, P. and Kulmala, M.: Station for Measuring EcosystemAtmosphere Relations (SMEAR II), Boreal Env. Res., 10, 315322, 2005.

Henschel, H., Navarro, J. C. A., Yli-Juuti, T., Kupiainen-Määttä, O., Olenius, T., Ortega, I. K., Clegg, S. L., Kurtén, T., Riipinen, I., and Vehkamäki, H.: Hydration of atmospherically relevant molecular clusters: Computational chemistry and classical thermodynamics, J. Phys. Chem. A, 118, 2599-2611, 2014.

Hodgman, C. D. (Ed.): CRC Handbook of Chemistry and Physics, 44th edition, The Chemical Rubber Publishing Co., Cleveland, OH, USA, 1962.

Huang, G., Hou, J., and Zhou, X.: A measurement method for atmospheric ammonia and primary amines based on aqueous sampling, OPA derivatization and HPLC analysis, Env. Sci. Tech., 43, 5851-5856, 2009.

IPCC: Climate Change 2013: the Physical Science Basis. Contribution of Working Group I to the Fifth Assessment Report of the Intergovernmental Panel on Climate Change, edited by: Stocker, T. F., Qin, D., Plattner, G.-K., Tignor, M., Allen, S. K., Boschung, J., Nauels, A., Xia, Y., Bex, V., and Midgley, P. M., Cambridge University Press, Cambridge, UK, and New York, NY, USA, 2013.

Janson, R., Rosman, K., Karlsson, A., and Hansson, H.-C.: Biogenic emissions and gaseous precursors to forest aerosols, Tellus B, 53, 423-440, 2001.

Jen, C. N., McMurry, P. H., and Hanson, D. R.: Stabilization of sulfuric acid dimers by ammonia, methylamine, dimethylamine, and trimethylamine, J. Geophys. Res. Atmos., 119, 7502-7514, 2014.

Johnson, C. J. and Johnson, M. A.: Vibrational spectra and fragmentation pathways of size-selected, D2-tagged ammonium/methylammonium bisulfate clusters, J. Phys. Chem. A, 117, 13265-13274, 2013.

Junninen, H., Ehn, M., Petäjä, T., Luosujärvi, L., Kotiaho, T., Kostiainen, R., Rohner, U., Gonin, M., Fuhrer, K., Kulmala, M., and Worsnop, D. R.: A high-resolution mass spectrometer to measure atmospheric ion composition, Atmos. Meas. Tech., 3, 10391053, 2010, http://www.atmos-meas-tech.net/3/1039/2010/.

Kazil, J., Stier, P., Zhang, K., Quaas, J., Kinne, S., O’Donnell, D., Rast, S., Esch, M., Ferrachat, S., Lohmann, U., and Feichter, J.: Aerosol nucleation and its role for clouds and Earth's radiative forcing in the aerosol-climate model ECHAM5-HAM, Atmos. Chem. Phys., 10, 10733-10752, doi:10.5194/acp-1010733-2010, 2010.

Kerminen, V.-M., Paramonov, M., Anttila, T., Riipinen, I., Fountoukis, C., Korhonen, H., Asmi, E., Laakso, L., Lihavainen, H., 
Swietlicki, E., Svenningsson, B., Asmi, A., Pandis, S. N., Kulmala, M., and Petäjä, T.: Cloud condensation nuclei production associated with atmospheric nucleation: a synthesis based on existing literature and new results, Atmos. Chem. Phys., 12, $12037-$ 12059, doi:10.5194/acp-12-12037-2012, 2012.

Keskinen, H., Virtanen, A., Joutsensaari, J., Tsagkogeorgas, G., Duplissy, J., Schobesberger, S., Gysel, M., Riccobono, F., Slowik, J. G., Bianchi, F., Yli-Juuti, T., Lehtipalo, K., Rondo, L., Breitenlechner, M., Kupc, A., Almeida, J., Amorim, A., Dunne, E. M., Downard, A. J., Ehrhart, S., Franchin, A., Kajos, M.K., Kirkby, J., Kürten, A., Nieminen, T., Makhmutov, V., Mathot, S., Miettinen, P., Onnela, A., Petäjä, T., Praplan, A., Santos, F. D., Schallhart, S., Sipilä, M., Stozhkov, Y., Tomé, A., Vaattovaara, P., Wimmer, D., Prevot, A., Dommen, J., Donahue, N. M., Flagan, R.C., Weingartner, E., Viisanen, Y., Riipinen, I., Hansel, A., Curtius, J., Kulmala, M., Worsnop, D. R., Baltensperger, U., Wex, H., Stratmann, F., and Laaksonen, A.: Evolution of particle composition in CLOUD nucleation experiments, Atmos. Chem. Phys., 13, 5587-5600, doi:10.5194/acp13-5587-2013, 2013.

Kirkby, J., Curtius, J., Almeida, J., Dunne, E., Duplissy, J., Ehrhart, S., Franchin, A., Gagné, S., Ickes, L., Kürten, A., Kupc, A., Metzger, A., Riccobono, F., Rondo, L., Schobesberger, S., Tsagkogeorgas, G., Wimmer, D., Amorim, A., Bianchi, F., Breitenlechner, M., David, A., Dommen, J., Downard, A., Ehn, M., Flagan, R. C., Haider, S., Hansel, A., Hauser, D., Jud, W., Junninen, H., Kreissl, F., Kvashin, A., Laaksonen, A., Lehtipalo, K., Lima, J., Lovejoy, E. R., Makhmutov, V., Mathot, S., Mikkilä, J., Minginette, P., Mogo, S., Nieminen, T., Onnela, A., Pereira, P., Petäjä, T., Schnitzhofer, R., Seinfeld, J. H., Sipilä, M., Stozhkov, Y., Stratmann, F., Tomé, A., Vanhanen, J., Viisanen, Y., Vrtala, A., Wagner, P. E., Walther, H., Weingartner, E., Wex, H., Winkler, P. M., Carslaw, K. S., Worsnop, D. R., Baltensperger, U., and Kulmala, M.: Role of sulphuric acid, ammonia and galactic cosmic rays in atmospheric aerosol nucleation, Nature, 476, 429-433, 2011.

Kontkanen, J., Lehtinen, K. E. J., Nieminen, T., Manninen, H. E., Lehtipalo, K., Kerminen, V.-M., and Kulmala, M.: Estimating the contribution of ion-ion recombination to sub- $2 \mathrm{~nm}$ cluster concentrations from atmospheric measurements, Atmos. Chem. Phys., 13, 11391-11401, doi:10.5194/acp-13-11391-2013, 2013.

Kuang, C., McMurry, P. H., McCormick, A. V., and Eisele, F. L.: Dependence of nucleation rates on sulfuric acid vapor concentration in diverse atmospheric locations, J. Geophys. Res., 113, D10209, doi:10.1029/2007jd009253, 2008.

Kulmala, M. and Kerminen, V.-M.: On the formation and growth of atmospheric nanoparticles, Atmos. Res., 90, 132-150, 2008.

Kulmala, M., Toivonen, A., Mäkelä, J. M., and Laaksonen, A.: Analysis of the growth of nucleation mode particles observed in Boreal forest, Tellus B, 50, 449-462, 1998.

Kulmala, M., Suni, T., Lehtinen, K. E. J., Dal Maso, M., Boy, M., Reissell, A., Rannik, Ü., Aalto, P., Keronen, P., Hakola, H., Bäck, J., Hoffmann, T., Vesala, T., and Hari, P.: A new feedback mechanism linking forests, aerosols, and climate, Atmos. Chem. Phys., 4, 557-562, doi:10.5194/acp-4-557-2004, 2004a.

Kulmala, M., Vehkamäki, H., Petäjä, T., Dal Maso, M., Lauri, A., Kerminen, V.-M., Birmili, W., and McMurry, P. H.: Formation and growth rates of ultrafine atmospheric particles: a review of observations, J. Aerosol Sci., 35, 143-176, 2004 b.
Kulmala, M., Lehtinen, K. E. J., and Laaksonen, A.: Cluster activation theory as an explanation of the linear dependence between formation rate of $3 \mathrm{~nm}$ particles and sulphuric acid concentration, Atmos. Chem. Phys., 6, 787-793, doi:10.5194/acp-6-787-2006, 2006.

Kulmala, M., Kontkanen, J., Junninen, H., Lehtipalo, K., Manninen, H. E., Nieminen, T., Petäjä, T., Sipilä, M., Schobesberger, S., Rantala, P., Franchin, A., Jokinen, T., Järvinen, E., Äijälä, M., Kangasluoma, J., Hakala, J., Aalto, P. P., Paasonen, P., Mikkilä, J., Vanhanen, J., Aalto, J., Hakola, H., Makkonen, U., Ruuskanen, T., Mauldin, R. L., 3rd, Duplissy, J., Vehkamäki, H., Bäck, J., Kortelainen, A., Riipinen, I., Kurtén, T., Johnston, M. V., Smith, J. N., Ehn, M., Mentel, T. F., Lehtinen, K. E., Laaksonen, A., Kerminen, V.-M., and Worsnop, D. R.: Direct observations of atmospheric aerosol nucleation, Science, 339, 943-946, 2013.

Kulmala, M., Petäjä, T., Ehn, M., Thornton, J., Sipilä, M., Worsnop, D. R., and Kerminen, V.-M.: Chemistry of atmospheric nucleation: on the recent advances on precursor characterization and atmospheric cluster composition in connection with atmospheric new particle formation, Annu. Rev. Phys. Chem., 65, 2137, 2014.

Kupc, A., Amorim, A., Curtius, J., Danielczok, A., Duplissy, J., Ehrhart, S., Walther, H., Ickes, L., Kirkby, J., Kürten, A., Lima, J. M., Mathot, S., Minginette, P., Onnela, A., Rondo, L., and Wagner, P. E.: A fibre-optic UV system for $\mathrm{H}_{2} \mathrm{SO}_{4}$ production in aerosol chambers causing minimal thermal effects, J. Aerosol Sci., 42, 532-543, 2011.

Kupiainen, O., Olenius, T., Ortega, I. K., Kurtén, T., and Vehkamäki, H.: Ion-induced vs. base-induced sulfuric acid cluster formation, in: Report Series in Aerosol Science, Finnish Association for Aerosol Research, 134, 398-400, Helsinki, Finland, 2012.

Kürten, A., Rondo, L., Ehrhart, S., and Curtius, J.: Calibration of a chemical ionization mass spectrometer for the measurement of gaseous sulfuric acid, J. Phys. Chem. A, 116, 6375-6386, 2012.

Kürten, A., Rondo, L., Ehrhart, S., and Curtius, J.: Performance of a corona ion source for measurement of sulfuric acid by chemical ionization mass spectrometry, Atmos. Meas. Tech., 4, 437-443, doi:10.5194/amt-4-437-2011, 2011.

Kurtén, T., Loukonen, V., Vehkamäki, H., and Kulmala, M.: Amines are likely to enhance neutral and ion-induced sulfuric acid-water nucleation in the atmosphere more effectively than ammonia, Atmos. Chem. Phys., 8, 4095-4103, doi:10.5194/acp-8-4095-2008, 2008.

Kurtén, T., Berndt, T., and Stratmann, F.: Hydration increases the lifetime of $\mathrm{HSO}_{5}$ and enhances its ability to act as a nucleation precursor - a computational study, Atmos. Chem. Phys., 9, 33573369, doi:10.5194/acp-9-3357-2009, 2009.

Kurtén, T., Torpo, L., Ding, C.-G., Vehkamäki, H., Sundberg, M. R., Laasonen, K., and Kulmala, M.: A density functional study on water-sulfuric acid-ammonia clusters and implications for atmospheric cluster formation, J. Geophys. Res., 112, D04210, doi:10.1029/2006JD007391, 2007a.

Kurtén, T., Torpo, L., Sundberg, M. R., Kerminen, V.-M., Vehkamäki, H., and Kulmala, M.: Estimating the $\mathrm{NH}_{3}: \mathrm{H}_{2} \mathrm{SO}_{4}$ ratio of nucleating clusters in atmospheric conditions using quantum chemical methods, Atmos. Chem. Phys., 7, 2765-2773, doi:10.5194/acp-7-2765-2007, 2007b. 
Lee, L. A., Pringle, K. J., Reddington, C. L., Mann, G. W., Stier, P., Spracklen, D. V., Pierce, J. R., and Carslaw, K. S.: The magnitude and causes of uncertainty in global model simulations of cloud condensation nuclei, Atmos. Chem. Phys., 13, 8879-8914, doi:10.5194/acp-13-8879-2013, 2013.

Lehtipalo, K., Kontkanen, J., Leppä, J., Kangasluoma, J., Franchin, A., Wimmer, D., Schobesberger, S., Junninen, H., Petäjä, T., Sipilä, M., Mikkilä, J., Vanhanen, J., Worsnop, D. R., and Kulmala, M.: Methods for determining particle size distribution and growth rates between 1 and $3 \mathrm{~nm}$ using the particle size magnifier, Boreal Env. Res., 19 (Suppl. B), 215-236, 2014.

Lovejoy, E. R., Curtius, J., and Froyd, K. D.: Atmospheric ioninduced nucleation of sulfuric acid and water, J. Geophys. Res., 109, D08204, doi:10.1029/2003JD004460, 2004.

Makkonen, R., Asmi, A., Kerminen, V. M., Boy, M., Arneth, A., Guenther, A., and Kulmala, M.: BVOC-aerosol-climate interactions in the global aerosol-climate model ECHAM5.5-HAM2, Atmos. Chem. Phys., 12, 10077-10096, 2012, http://www.atmos-chem-phys.net/12/10077/2012/.

Makkonen, U., Virkkula, A., Hellén, H., Hemmilä, M., Sund, J., Äijälä, M., Ehn, M., Junninen, H., Keronen, P., Petäjä, T., Worsnop, D. R., Kulmala, M., and Hakola, H.: Semi-continuous gas and inorganic aerosol measurements at a boreal forest site: seasonal and diurnal cycles of $\mathrm{NH}_{3}, \mathrm{HONO}$ and $\mathrm{HNO}_{3}$, Boreal Env. Res., 19 (suppl. B), 311-328, 2014.

Marti, J. J., Jefferson, A., Cai, X. P., Richert, C., McMurry, P. H., and Eisele, F.: $\mathrm{H}_{2} \mathrm{SO}_{4}$ vapor pressure of sulfuric acid and ammonium sulfate solutions, J. Geophys. Res., 102, 3725-3735, 1997.

McGrath, M. J., Olenius, T., Ortega, I. K., Loukonen, V., Paasonen, P., Kurtén, T., Kulmala, M., and Vehkamäki, H.: Atmospheric Cluster Dynamics Code: a flexible method for solution of the birth-death equations, Atmos. Chem. Phys., 12, 2345-2355, doi:10.5194/acp-12-2345-2012, 2012.

Merikanto, J., Spracklen, D. V., Mann, G. W., Pickering, S. J., and Carslaw, K. S.: Impact of nucleation on global CCN, Atmos. Chem. Phys., 9, 8601-8616, doi:10.5194/acp-9-8601-2009, 2009.

Metzger, A., Verheggen, B., Dommen, J., Duplissy, J., Prevot, A. S. H., Weingartner, E., Riipinen, I., Kulmala, M., Spracklen, D. V., Carslaw, K. S., and Baltensperger, U.: Evidence for the role of organics in aerosol particle formation under atmospheric conditions, Proc. Natl. Acad. Sci. USA, 107, 6646-6651, 2010.

Mirme, S., Mirme, A., Minikin, A., Petzold, A., Hõrrak, U., Kerminen, V. -M., and Kulmala, M.: Atmospheric sub-3 nm particles at high altitudes, Atmos. Chem. Phys., 10, 437-451, doi:10.5194/acp-10-437-2010, 2010.

Möhler, O., Reiner, T., and Arnold, F.: The formation of $\mathrm{SO}_{5}^{-}$by gas phase ion-molecule reactions, J. Chem. Phys., 97, 8233-8239, 1992.

Nadykto, A. B., Yu, F., Jakovleva, M. V., Herb, J., and Xu, Y.: Amines in the earth's atmosphere: A density functional theory study of the thermochemistry of pre-nucleation clusters, Entropy, 13, 554-569, 2011.

Norman, M., Hansel, A., and Wisthaler, A.: $\mathrm{O}_{2}^{+}$as reagent ion in the PTR-MS instrument: Detection of gas-phase ammonia, Int. J. Mass. Spectrom., 265, 382-387, 2007.

O’Dowd, C. D., Yoon, Y. J., Junkermann, W., Aalto, P., Kulmala, M., Lihavainen, H., and Viisanen, Y.: Airborne measurements of nucleation mode particles II: boreal forest nucleation events, Atmos. Chem. Phys., 9, 937-944, doi:10.5194/acp-9937-2009, 2009.

Olenius, T., Kupiainen-Määttä, O., Ortega, I. K., Kurtén, T., and Vehkamäki, H.: Free energy barrier in the growth of sulfuric acid-ammonia and sulfuric acid-dimethylamine clusters, J. Chem. Phys., 139, 084312, doi:10.1063/1.4819024, 2013a.

Olenius, T., Schobesberger, S., Kupiainen, O., Franchin, A., Junninen, H., Ortega, I. K., Kurtén, T., Loukonen, V., Worsnop, D. R., Kulmala, M., and Vehkamäki, H.: Comparing simulated and experimental molecular cluster distributions, Farad. Discuss., 165, 75-89, 2013b.

Ortega, I. K., Kurtén, T., Vehkamäki, H., and Kulmala, M.: The role of ammonia in sulfuric acid ion induced nucleation, Atmos. Chem. Phys., 8, 2859-2867, doi:10.5194/acp-8-2859-2008, 2008.

Ortega, I. K., Kupiainen, O., Kurtén, T., Olenius, T., Wilkman, O., McGrath, M. J., Loukonen, V., and Vehkamäki, H.: From quantum chemical formation free energies to evaporation rates, Atmos. Chem. Phys., 12, 225-235, 2012,

http://www.atmos-chem-phys.net/12/225/2012/.

Ortega, I. K., Olenius, T., Kupiainen-Määttä, O., Loukonen, V., Kurtén, T., and Vehkamäki, H.: Electrical charging changes the composition of sulfuric acid-ammonia/dimethylamine clusters, Atmos. Chem. Phys., 14, 7995-8007, doi:10.5194/acp-14-79952014, 2014.

Osada, K., Ueda, S., Egashira, T., Takami, A., and Kaneyasu, N.: Measurements of gaseous $\mathrm{NH}_{3}$ and particulate $\mathrm{NH}_{4}^{+}$in the atmosphere by fluorescent detection after continuous air-water droplet sampling, Aerosol Air Qual. Res., 11, 170-178, 2011.

Paasonen, P., Olenius, T., Kupiainen, O., Kurtén, T., Petäjä, T., Birmili, W., Hamed, A., Hu, M., Huey, L. G., Plass-Duelmer, C., Smith, J. N., Wiedensohler, A., Loukonen, V., McGrath, M. J., Ortega, I. K., Laaksonen, A., Vehkamäki, H., Kerminen, V.-M., and Kulmala, M.: On the formation of sulphuric acid - amine clusters in varying atmospheric conditions and its influence on atmospheric new particle formation, Atmos. Chem. Phys., 12, 9113-9133, doi:10.5194/acp-12-9113-2012, 2012.

Petäjä, T., Sipilä, M., Paasonen, P., Nieminen, T., Kurtén, T., Ortega, I. K., Stratmann, F., Vehkamäki, H., Berndt, T., and Kulmala, M.: Experimental observation of strongly bound dimers of sulfuric acid: Application to nucleation in the atmosphere, Phys. Rev. Lett., 106, 228302, 2011.

Praplan, A. P., Bianchi, F., Dommen, J., and Baltensperger, U.: Dimethylamine and ammonia measurements with ion chromatography during the CLOUD4 campaign, Atmos. Meas. Tech., 5, 2161-2167, doi:10.5194/amt-5-2161-2012, 2012.2.

Riccobono, F., Schobesberger, S., Scott, C. E., Dommen, J., Ortega, I. K., Rondo, L., Almeida, J., Amorim, A., Bianchi, F., Breitenlechner, M., David, A., Downard, A., Dunne, E. M., Duplissy, J., Ehrhart, S., Flagan, R. C., Franchin, A., Hansel, A., Junninen, H., Kajos, M., Keskinen, H., Kupc, A., Kürten, A., Kvashin, A. N., Laaksonen, A., Lehtipalo, K., Makhmutov, V., Mathot, S., Nieminen, T., Onnela, A., Petäjä, T., Praplan, A. P., Santos, F. D., Schallhart, S., Seinfeld, J. H., Sipilä, M., Spracklen, D. V., Stozhkov, Y., Stratmann, F., Tomé, A., Tsagkogeorgas, G., Vaattovaara, P., Viisanen, Y., Vrtala, A., Wagner, P. E., Weingartner, E., Wex, H., Wimmer, D., Carslaw, K. S., Curtius, J., Donahue, N. M., Kirkby, J., Kulmala, M., Worsnop, D. R., and Baltensperger, U.: Oxidation products of biogenic emissions con- 
tribute to nucleation of atmospheric particles, Science, 344, 717721, 2014.

Riipinen, I., Sihto, S.-L., Kulmala, M., Arnold, F., Dal Maso, M., Birmili, W., Saarnio, K., Teinilä, K., Kerminen, V.-M., Laaksonen, A., and Lehtinen, K. E. J.: Connections between atmospheric sulphuric acid and new particle formation during QUEST III-IV campaigns in Heidelberg and Hyytiälä, Atmos. Chem. Phys., 7, 1899-1914, doi:10.5194/acp-7-1899-2007, 2007.

Rozenberg, M., Loewenschuss, A., and Nielsen, C. J.: Complexes of molecular and ionic character in the same matrix layer: Infrared studies of the sulfuric acid/ammonia system, J. Phys. Chem. A, 115, 5759-5766, 2011.

Schnitzhofer, R., Metzger, A., Breitenlechner, M., Jud, W., Heinritzi, M., De Menezes, L.-P., Duplissy, J., Guida, R., Haider, S., Kirkby, J., Mathot, S., Minginette, P., Onnela, A., Walther, H., Wasem, A., Hansel, A., and the CLOUD Team: Characterisation of organic contaminants in the CLOUD chamber at CERN, Atmos. Meas. Tech., 7, 2159-2168, doi:10.5194/amt-7-2159-2014, 2014.

Schobesberger, S., Junninen, H., Bianchi, F., Lönn, G., Ehn, M., Lehtipalo, K., Dommen, J., Ehrhart, S., Ortega, I. K., Franchin, A., Nieminen, T., Riccobono, F., Hutterli, M., Duplissy, J., Almeida, J., Amorim, A., Breitenlechner, M., Downard, A. J., Dunne, E. M., Flagan, R. C., Kajos, M., Keskinen, H., Kirkby, J., Kupc, A., Kürten, A., Kurtén, T., Laaksonen, A., Mathot, S., Onnela, A., Praplan, A. P., Rondo, L., Santos, F. D., Schallhart, S., Schnitzhofer, R., Sipilä, M., Tomé, A., Tsagkogeorgas, G., Vehkamäki, H., Wimmer, D., Baltensperger, U., Carslaw, K. S., Curtius, J., Hansel, A., Petäjä, T., Kulmala, M., Donahue, N. M., and Worsnop, D. R.: Molecular understanding of atmospheric particle formation from sulfuric acid and large oxidized organic molecules, Proc. Natl. Acad. Sci. USA, 110, 1722317228, 2013a.

Schobesberger, S., Väänänen, R., Leino, K., Virkkula, A., Backman, J., Pohja, T., Siivola, E., Franchin, A., Mikkilä, J., Paramonov, M., Aalto, P. P., Krejci, R., Petäjä, T., and Kulmala, M.: Airborne measurements over the boreal forest of southern Finland during new particle formation events in 2009 and 2010, Boreal Env. Res., 18, 145-163, 2013b.

Sipilä, M., Berndt, T., Petäjä, T., Brus, D., Vanhanen, J., Stratmann, F., Patokoski, J., Mauldin, R. L., Hyvärinen, A. P., Lihavainen, H., and Kulmala, M.: The role of sulfuric acid in atmospheric nucleation, Science, 327, 1243-1246, 2010.
VandenBoer, T. C., Petroff, A., Markovic, M. Z., and Murphy, J. G.: Size distribution of alkyl amines in continental particulate matter and their online detection in the gas and particle phase, Atmos. Chem. Phys., 11, 4319-4332, doi:10.5194/acp-11-43192011, 2011.

Vehkamäki, H., Kulmala, M., Napari, I., Lehtinen, K. E. J., Timmreck, C., Noppel, M., and Laaksonen, A.: An improved parameterization for sulfuric acid/water nucleation rates for tropospheric and stratospheric conditions, J. Geophys. Res., 107, AAC 3-1AAC 3-10, 2002.

Voigtländer, J., Duplissy, J., Rondo, L., Kürten, A., and Stratmann, F.: Numerical simulations of mixing conditions and aerosol dynamics in the CERN CLOUD chamber, Atmos. Chem. Phys., 12, 2205-2214, doi:10.5194/acp-12-2205-2012, 2012.

von Bobrutzki, K., Braban, C. F., Famulari, D., Jones, S. K., Blackall, T., Smith, T. E. L., Blom, M., Coe, H., Gallagher, M., Ghalaieny, M., McGillen, M. R., Percival, C. J., Whitehead, J. D., Ellis, R., Murphy, J., Mohacsi, A., Pogany, A., Junninen, H., Rantanen, S., Sutton, M. A., and Nemitz, E.: Field inter-comparison of eleven atmospheric ammonia measurement techniques, Atmos. Meas. Tech., 3, 91-112, doi:10.5194/amt-3-91-2010, 2010.

Weber, R. J., Marti, J., McMurry, P. H., Eisele, F. L., Tanner, D. J., and Jefferson, A.: Measured atmospheric new particle formation rates: implications for nucleation mechanisms, Chem. Eng. Comm, 151, 53-64, 1996.

Zhang, R., Suh, I., Zhao, J., Zhang, D., Fortner, E. C., Tie, X., Molina, L. T., and Molina, M. J.: Atmospheric new particle formation enhanced by organic acids, Science, 304, 1487-1490, 2004.

Zhao, J., Smith, J. N., Eisele, F. L., Chen, M., Kuang, C., and McMurry, P. H.: Observation of neutral sulfuric acid-amine containing clusters in laboratory and ambient measurements, Atmos. Chem. Phys., 11, 10823-10836, doi:10.5194/acp-1110823-2011, 2011.

Ziereis, H. and Arnold, F.: Gaseous ammonia and ammonium ions in the free troposphere, Nature, 321, 503-505, 1986. 